\title{
WestVirginiaUniversity
}

THE RESEARCH REPOSITORY @ WVU

Graduate Theses, Dissertations, and Problem Reports

2019

\section{A Pedagogical Guide to Kapustin's Eight Concert Etudes, Op. 40}

\author{
Yanjing Gu \\ West Virginia University, yagu@mix.wvu.edu
}

Follow this and additional works at: https://researchrepository.wvu.edu/etd

\section{Recommended Citation}

Gu, Yanjing, "A Pedagogical Guide to Kapustin's Eight Concert Etudes, Op. 40" (2019). Graduate Theses, Dissertations, and Problem Reports. 3819.

https://researchrepository.wvu.edu/etd/3819

This Dissertation is protected by copyright and/or related rights. It has been brought to you by the The Research Repository @ WVU with permission from the rights-holder(s). You are free to use this Dissertation in any way that is permitted by the copyright and related rights legislation that applies to your use. For other uses you must obtain permission from the rights-holder(s) directly, unless additional rights are indicated by a Creative Commons license in the record and/ or on the work itself. This Dissertation has been accepted for inclusion in WVU Graduate Theses, Dissertations, and Problem Reports collection by an authorized administrator of The Research Repository @ WVU.

For more information, please contact researchrepository@mail.wvu.edu. 
A Pedagogical Guide to Kapustin's Eight Concert Etudes, Op. 40

\author{
Yanjing Gu \\ A Doctoral Research Project \\ Submitted to the College of Creative Arts at \\ West Virginia University \\ in partial fulfillment of the requirements for the degree of \\ Doctor of Musical Arts in \\ Piano Performance
}
Peter Amstutz, D.M.A, Committee Chair and Research Advisor James Miltenberger, D.M.A
William Haller, D.M.A Andrea Houde, M.M., G.P.D.
Bruce Kang, Ph.D.
School of Music

Morgantown, West Virginia

2019

Keywords: Kapustin; Concert etudes; Prelude; Reverie; Toccatina; Reminiscence; Raillery; Pastoral; Intermezzo; Finale 


\section{ABSTRACT \\ A Pedagogical Guide to Kapustin's Eight Concert Etudes, Op. 40 \\ Yanjing $\mathrm{Gu}$}

The etude is an important genre in piano literature and most piano teachers select etudes as teaching material for students to improve their technique and musical sensitivity. As etudes developed and evolved, they have served not only for technical study, but also as concert repertoire that beautifully represents composers' personal styles. Since the initial appearance of the etude as a genre in the early $19^{\text {th }}$ century, composers from subsequent time periods have continued to write etudes.

While a number of scholarly works discuss etudes, relatively little attention has been devoted to etudes composed in the late 20th century, compared to those written in earlier periods. Therefore, with the goal of contributing to this field of endeavor, this research project investigates the Eight Concert Etudes, Op. 40, by Nikolai Kapustin (b. 1937), in part to explore how one late $20^{\text {th- }}$ century composer engaged with the traditional etude.

To provide a broader picture of the topic, this research project begins with a brief overview of the development of etudes as a genre, along with summaries of Kapustin's life and musical output. This general material is followed by discussion of the Eight Concert Etudes, including pedagogical suggestions and aspects of the musical forms and techniques that are commonly used in both classical and jazz music. Kapustin's compositional principles are explored in more detail in two of these etudes, No. 2 (Reverie) and No. 8 (Finale). 


\section{Acknowledgements}

First and foremost, I would sincerely like to thank my advisor, Dr. Peter Amstutz, for his endlessly kind support for me during my study at WVU. I really appreciate his advice on improving my piano skills, along with my knowledge and expression, as well as the tremendous amount of help and advice he provided for my research project.

Secondly, I am thankful to my doctoral committee members, Dr. James Miltenberger, Dr. William Haller, Prof. Andrea Houde, and Dr. Bruce Kang, for their valuable patience, guidance and support.

Finally, I would like to thank my parents and my husband for their infinite love, care and support. I also want to express my thanks to all my former piano teachers for guiding me on my journey in the piano world. 


\section{Table of Contents}

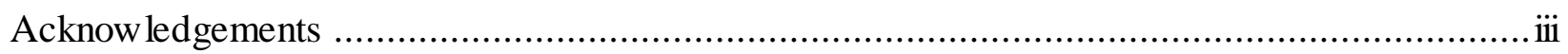

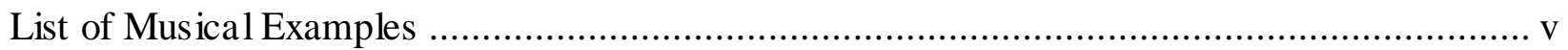

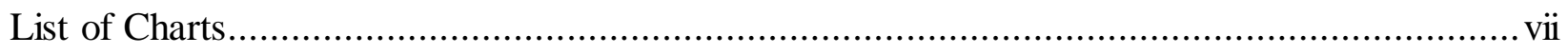

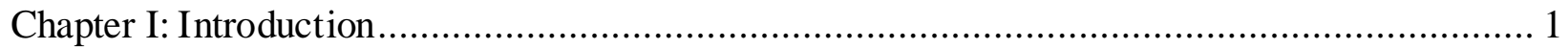

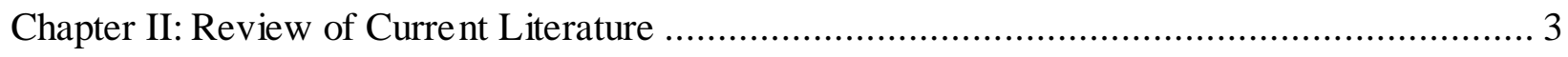

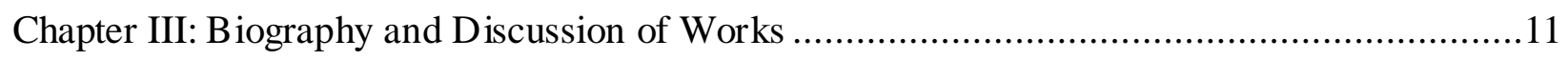

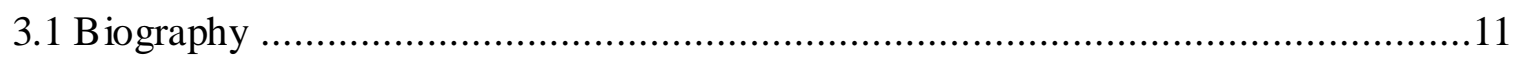

3.1.1 Early Life and Education ..................................................................

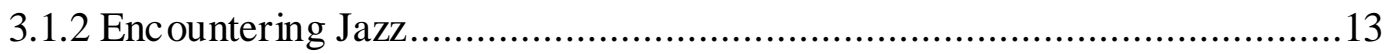

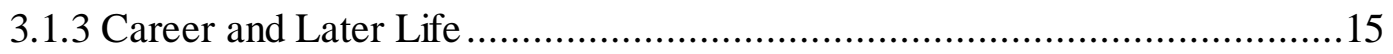

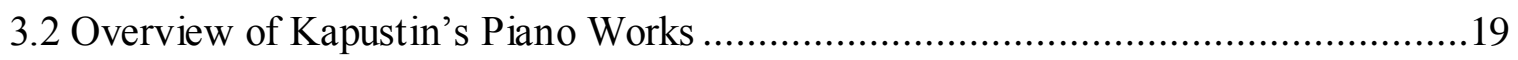

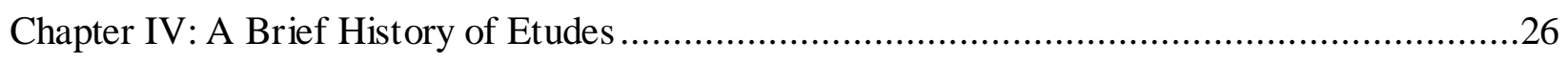

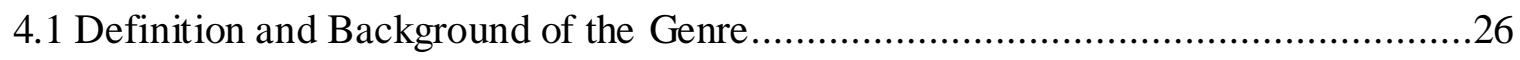

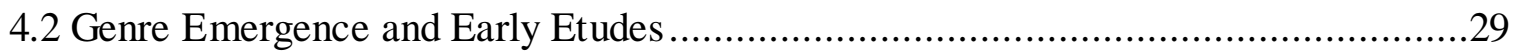

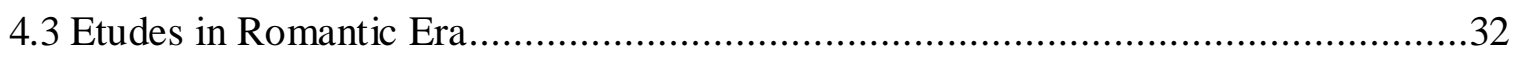

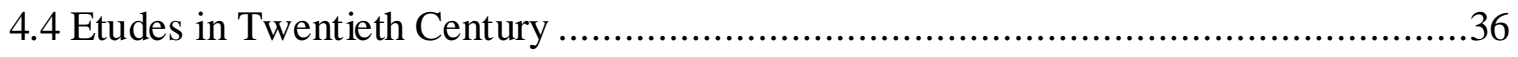

Chapter V. Analys is of the Eight Concert Etudes................................................................

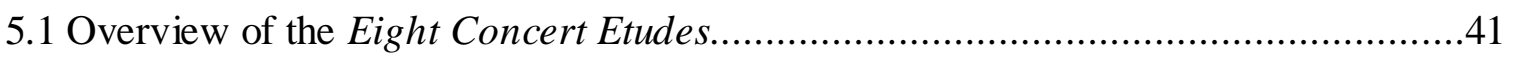

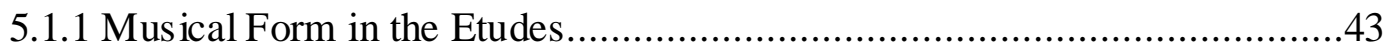

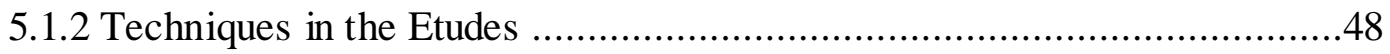

5.2 Analysis of Compositional Principles in Two Etudes .............................................60

5.2.1 Analysis of Etude No. 2 (Reverie) .......................................................60

5.2.2 Analysis of Etude No. 8 (Finale)..........................................................67

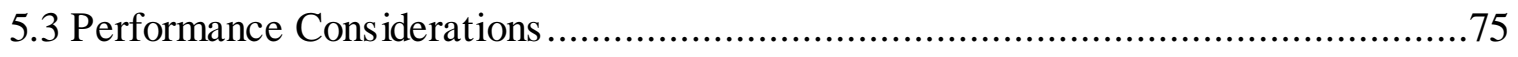

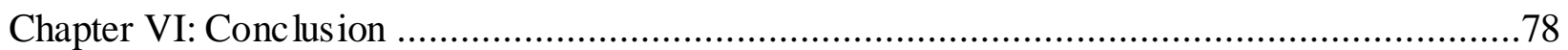

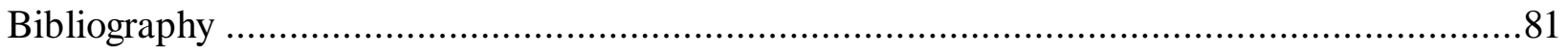




\section{List of Musical Examples}

Example 1: Etude No. 1, theme A, mm. 1-3 and the me B, mm. 13-14 …..............................43

Example 2: Etude No. 1, $1^{\text {st }}$ section B' $+A^{\prime}$ ' $m$ m. $29-40$ and $2^{\text {nd }}$ section B' $+A^{\prime}$, mm. $57-66 \ldots \ldots . .44$

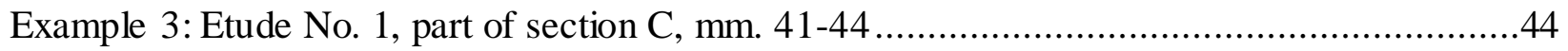

Example 4: Etude No. 7, part of mixing A\&B, mm. 90-94 ..................................................46

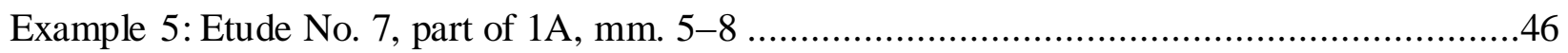

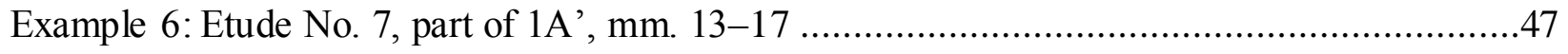

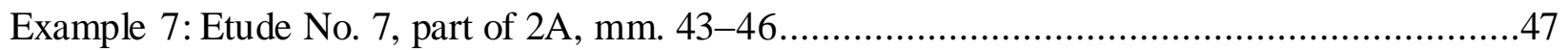

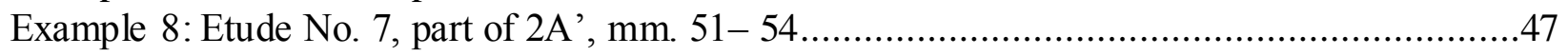

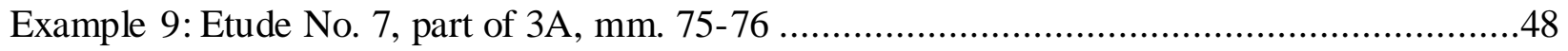

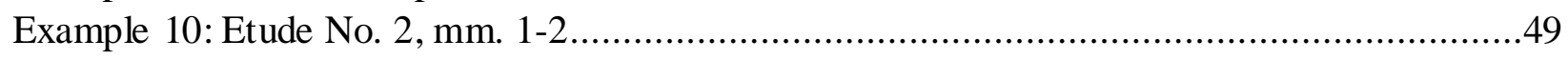

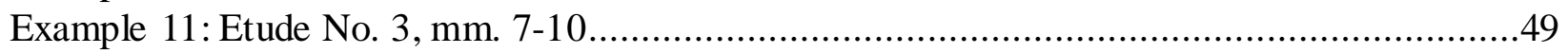

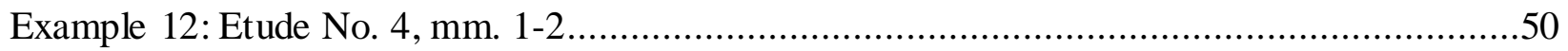

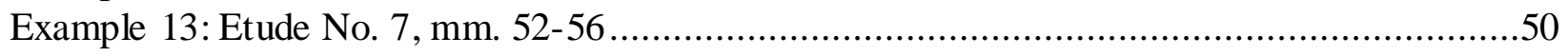

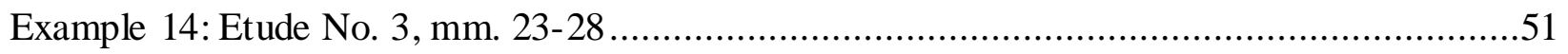

Example 15: Chopin's Etude, Op. 10, No. 12, mm. 64-69 ..................................................51

Example 16: Etude No. 2, mm. 1; Rachmaninoff's Prelude, Op. 23, No. 9, mm. 1-2 …............52

Example 17-a: Etude No. 3, mm. 51-54 ......................................................................52

Example 17-b: Rachmaninoff's Pia no Sonata No. 2, 3rd movement, mm. 288-293 …...............53

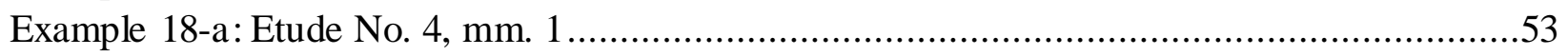

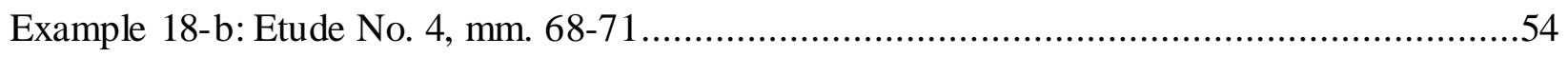

Example 19: $\mathrm{C}$ major and $\mathrm{c}$ minor pentatonic scales, and $\mathrm{C}$ blues scale ....................................55

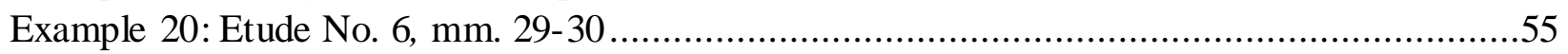

Example 21: Etude No. 1, A theme, mm. 1-3, and B theme, mm. 13-14 ...............................55

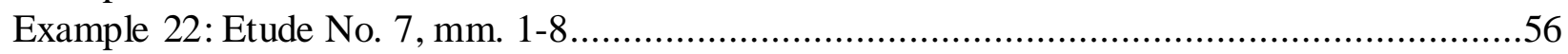

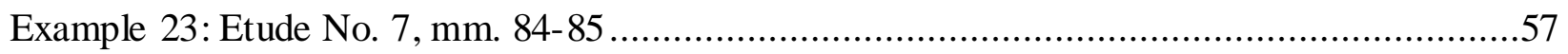

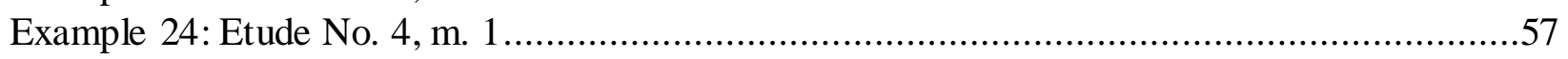

Example 25: 12-bar blues harmonic scheme in $\mathrm{C}$ major .....................................................5

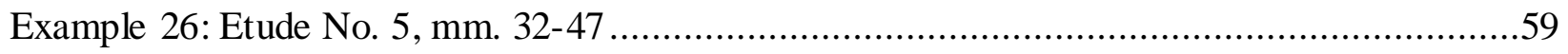

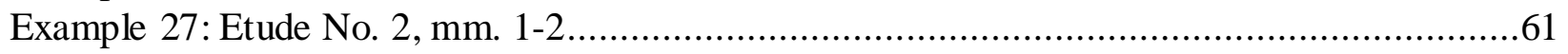

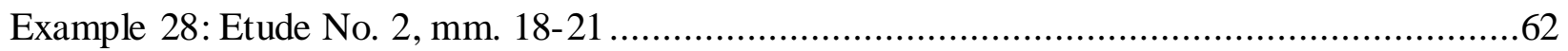

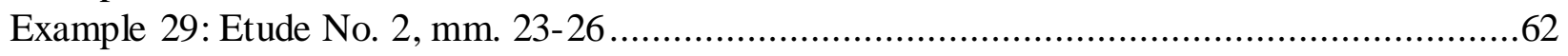

Example 30: Etude No. 2, theme b (mm. 27-34)/tremolo figure in b transition, mm. 35-

37/descending melodic 2nd in b' transition, mm. 51-52 ...................................................63

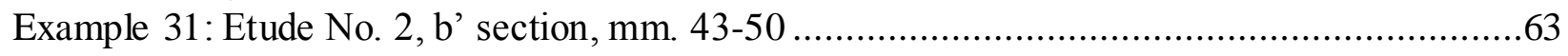

Example 32: Etude No. 2, beginning of c section (mm.59-62) and c' section (mm. 75-78) .......64

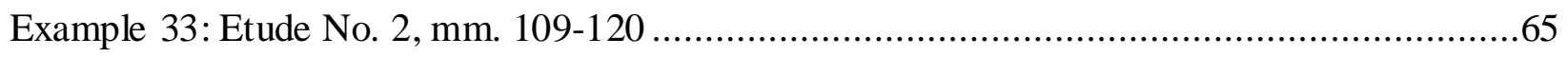

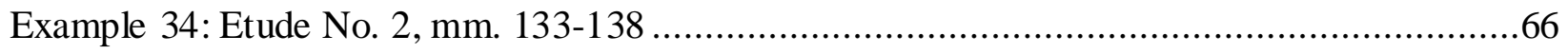

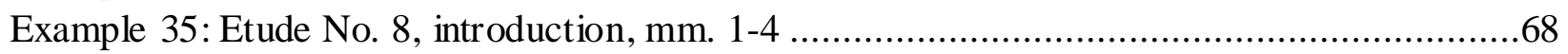


Example 36-a: Etude No. 8, mm. 5-8......................................................................68

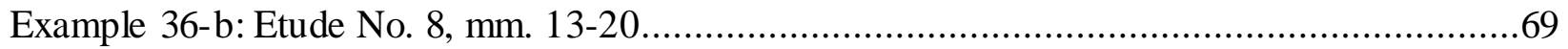

Example 37: Etude No. 8, mm. 33-44 ......................................................................69

Example 38: Etude No. 8, B section, mm 47-62/Etude No. 2, mm. 27- 52 ...........................70

Example 39: Etude No. 8, part of C section, mm. 63-72 ...................................................71

Example 40: Etude No. 8, trans ition, mm. 75-91 .......................................................... 72

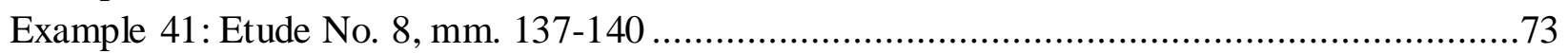

Example 42: Etude No. 8, mm. 149-152 _......................................................... 73

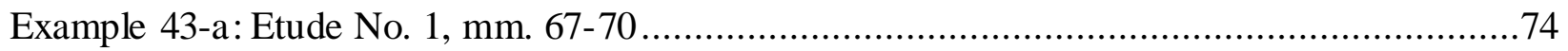

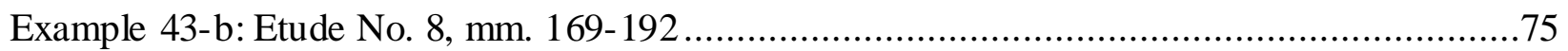

Example 44: Etude No. 5, mm. 68- 73 .....................................................................76

Example 45: No. 23 in $F$ major of 24 Preludes, Op. 53, mm. 37-42 .....................................76 


\section{List of Charts}

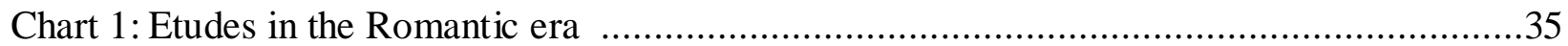

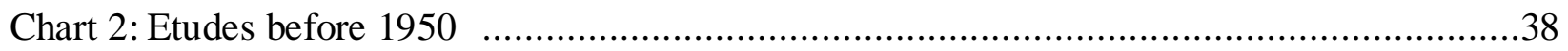

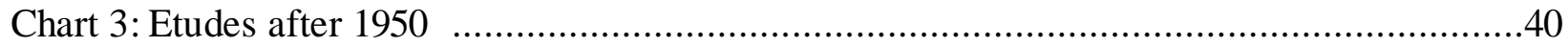

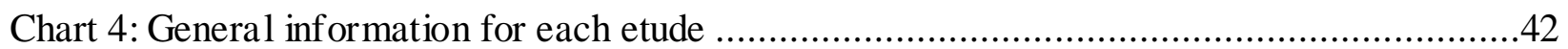

Chart 5: Etude No. 2 - form ....................................................................................60

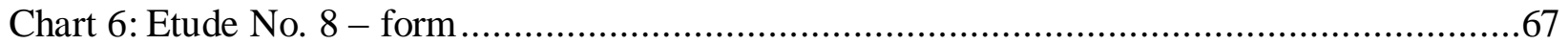




\section{Chapter I: Introduction}

The etude, as a genre, plays an important role in the repertoire for piano. It has evolved from soulless technical exercises to virtuosic concert pieces of true artistic merit. There are many wonderful piano etudes that are frequently chosen to be performed on recitals. These etudes are usually short and sparkling pieces, which may act as "appetizers," compared to a large "entrée" like a sonata, keyboard suite or other large-scale pieces on a recital program. Many etudes are exquisite, novel, and sophisticated. Therefore, many composers nowadays remain passionate about composing substantial numbers of piano etudes.

The Russian composer and pianist Nikolai Kapustin (born 1937) was an important musical figure during the second half of the $20^{\text {th }}$ century and his influence continues to increase through the present day. He wrote piano etudes which are considered a substantial contribution to the genre. His music style is distinct and easily recognizable, a fascinating fusion of classical forms with jazz stylistic and harmonic languages. This research project focuses on examining how Kapustin's music style engaged with the traditional etude genre through a representative investigation of Kapustin's Eight Concert Etudes, Op. 40. The purpose of this research project is to provide a clearer understanding of these etudes through analysis, along with pedagogical suggestions for performers.

This document consists of six chapters. Following the present introductory section, Chapter II provides a brief review of current literature about Kapustin's piano works, focusing especially on his etudes, which have not been comprehensively studied and which deserve further investigation. Chapter III provides biographical information about Nikolai Kapustin as a composer, including his early life and educational background, and how he encountered jazz music and became a productive composer; this is followed by an overview of his piano works. 
Chapter IV surveys the history of piano etudes, including the background of the genre, and its development in Baroque, Classic and Romantic eras, as well as during the $20^{\text {th }}$ century. This chapter introduces a large number of etudes, which could be helpful to teachers wishing to explore broader repertoire options as study materials. This repertoire can help to develop students' sense of musical styles in different periods, along with raising their technical skills and musical sensitivity. This information could also serve as a starting-off place for someone else launching a bigger study.

The discussions in Chapters I through IV lead to the essential focus of this research project in Chapter V, the introduction and investigation of Kapustin's Eight Concert Etudes, Op. 40. Chapter $\mathrm{V}$ provides an overview of the form and style of each piece, along with offering pedagogical suggestions related to practice and performance. It also explores two of the eight etudes, No. 2 (Reverie) and No. 8 (Finale), as typical examples for considering Kapustin's compositional principles in the etudes.

Chapter VI summarizes the conclusions of this exploration. The author hopes that this research project can assist other pianists and teachers in furthering their understanding of these challenging and fascinating pieces. 


\section{Chapter II: Review of Current Literature}

Although Kapustin's music has been receiving more and more performances in the past few decades, published discussions of Kapustin and his works have appeared only in several research dissertations and a small number of articles in newspapers and journals. Within these sources, only a relatively small number of his works have been specifically addressed and analyzed.

As discussed in Leslie De'Ath's article "Nikolai Kapustin—a Performer's Perspective,"1 published in 2002, though Kapustin's music is attracting more and more attention in the classicalmusic world nowadays, it remains in favor only within a limited group that is far smaller than perhaps it should be. De'Ath suggests that this may be because Kapustin does not like selfpromotional activities and because the special style of his pieces might limit demand among performers to play them.

In order to show an overall picture of current literature and resources that discuss Kapustin, this chapter is divided into three major categories: online sources, dissertations and theses, and periodicals.

\section{Online Sources}

Grove Music Online 2 is a comprehensive music encyclopedia, yet it only provides a few articles discussing Kapustin:

"Kapustin, Nikolay Girshevich," written by Alla Vladimirovna Grigor'yeva. ${ }^{3}$ "Third Stream," written by Gunther Schuller and Thomas H. Greenland. ${ }^{4}$

\footnotetext{
${ }^{1}$ Les lie De’Ath, “Nikolai Kapustin-A Performer's Perspective,” MusicWeb International (June 2002), http://www.musicweb-international.com/classRev/2002/Jun02/Kapustin.htm(accessed June 20, 2014)

2 "Oxford Music Online," accessed Nov.20, 2018, http://www.oxfordmusiconline.com/.

${ }^{3}$ Alla Vladimirovna Grigor'yeva, "Kapustin, Nikolay Girs hevich," The New Grove Dictionaryof Music and Musicians, 2001.
} 
Although the available information is limited, the reader can certainly explore the composer's historic pathways, including his personal life, music career, and evolution of composition styles.

Nikolai-Kapustin.info, ${ }^{5}$ a website managed by Wim de Haan with Kapustin's official endorsement, offers a comprehensive introduction to Kapustin and his music. The site provides a detailed biography and an overview of all his compositions. Most importantly, audio and video recordings of most of his released music and some unreleased music, are available directly on the website, which offers extremely convenient access to Kapustin's music for those who are interested. Some of these recordings are performed by Kapustin himself.

Musicweb-international.com ${ }^{6}$ is one of the largest non-commercial classical music resources; it was founded in the United Kingdom in 1995. It posts new classical CD and DVD reviews every weekday and also sells albums/discs with the sale links under the review pages as one source of raising funds for the operation of this website. The website also provides research resources and articles. A few sources about Kapustin's music appear on this site. Most of these are reviews of Kapustin's CD recordings. Leslie De'Ath's previously mentioned article, 'Nicolai Kapustin—a Performer's Perspective," was published here. ${ }^{7}$ This article is a great source for gaining a general understanding of Kapustin and his music. It provides a short biography of Kapustin and a brief summary of his music works, with a concise discussion of his piano works, for example the key organization in the 24 Preludes and Fugues, Op. 82. De'Ath's article also

\footnotetext{
${ }^{4}$ Gunther Schuller and Thomas H. Greenland, "Third stream," https://doi.org/10.1093/gmo/9781561592630.article.A2252527 (accessed March 01, 2019).

5 “Nikolai Kapustin," accessed Nov. 10, 2018, http://www.nikolai-kapustin.info/.

6 "MusicWeb International: Clas sical Music Reviews \& Resources," accessed Nov. 10, 2018, http://musicwebinternational.com/.

${ }^{7}$ De'Ath, "Performer's Pers pective."
} 
reveals that Kapustin's musical style belongs to the "Third Stream" trend ${ }^{8}$ of the later 20th century and provides a short discussion and suggestions from a performance-practice viewpoint on how a classical pianist can learn jazz-style music.

\section{Dissertations and Theses}

Compared to the online sources, more relevant information about Kapustin appears in dissertations and theses. It is likely that no dissertation on Kapustin appeared before 2000. Now that his popularity continues to grow, more papers have come out during the past few years. One of the earliest dissertations on Kapustin was written by Jonathan Edward Mann (the grandson of a famous American musicologist, Dr. Alfred Mann"), entitled "Red, White and Blue Notes: The Symbiotic Music of Nikolai Kapustin,"10 published in 2007. This dissertation addresses the debate over whether Kapustin's music is classical or jazz, and discusses the ways in which Kapustin blends classical form and jazz texture in Chapter I. ${ }^{11}$ Particularly, it points out Kapustin uses the language of jazz improvisation, but without actually requiring improvisation on stage. On the contrary, the "improvisation" is written down by utilizing jazz harmonic language, notated swing rhythms, and syncopation to provide the effect that the jazz style produces. ${ }^{12}$ Kapustin's musical background and education, and his placement in the history of jazz in Russia are investigated in Chapter II, followed by detailed analyses of three solo piano works:

Reconciling Classical Form and Jazz Harmony in Sonatina, Op. 100 (Chapter III); Harmonic

\footnotetext{
${ }^{8}$ Third Stream: a category of music that synthesizes jazz and clas sical musical elements. Improvisation is generally seen as a vital component of Third Stream.

${ }^{9}$ Yana Tyulkova, "Classical and Jazz Influences in the Music of Nikolai Kapustin: Piano Sonata No. 3, Op. 55" (DMA diss., West Virginia University, 2015), 4.

${ }^{10}$ Jonathan Edward Mann, "Red, White, and Blue Notes: The Symbiotic Music of Nikolai Kapustin" (PhD diss., University of Cincinnati, 2007).

${ }^{11}$ Mann, "Red, White, and Blue Notes," 2.

${ }^{12}$ Mann, "Red, White, and Blue Notes," 6-18.
} 
Analysis of Prelude No. 9 in E Major, Op. 53 (Chapter IV); and Formal Analysis of Fugue No. 1 in C Major, Op. 82 (Chapter V).

Among the authors who wrote dissertations on the music of Nikola Kapustin, Yana Tyulkova, a Russian-born classical pianist who was also trained as a jazz vocalist and jazz pianist, has had multiple opportunities to meet with Nikolai Kapustin for personal interviews. Her dissertation, "Classical and Jazz influences in the Music of Nikolai Kapustin: Piano Sonata No. 3, Op. 55," was published in 2015. It provides fascinating information based on her face-toface interviews with Kapustin, especially pointing out some specific dates and events that influenced and directed Kapustin's career as a composer. ${ }^{13}$ The Kapustin biography in Tyulkova's Chapter 3 was selected to be posted on Kapustin's official website. This dissertation has seven chapters. The opening chapter provides historical and biographical information and discusses stylistic influences, followed by an overview of Kapustin's 20 piano sonatas. The main body of the paper examines Sonata No. 3, Op. 55, with form and style analysis, and general performance suggestions as well.

There are three dissertations addressing topics which are similar or related to this project. One was written by Tatiana Abramova and is entitled "The synthesis of jazz and classical styles in three piano works of Nikolai Kapustin." ${ }^{14}$ It consists of six chapters, as shown below:

1. Introduction -- The biography of Nikolai Kapustin. General description of composer's style

2. The history of jazz tradition in Russia

3. The analysis of Kapustin's Variations, Op. 41

4. The analysis of compositional principles in two Concert Etudes from Eight Concert Etudes, Op. 40

5. Discussion of the pedagogical value of Kapustin's compositions: pedagogical and performance implications. Comparison of two interpretations of Etudes \#3 and \#4: Nikolai Kapustin and Marc-André Hamelin

6. Conclusion

\footnotetext{
${ }^{13}$ Tyulkova, "Clas sical and Jazz Influences," 5.

${ }^{14}$ Tatiana Abramova, "The Synthesis of Jazzand Classical Styles in Three Piano W orks of Nikolai Kapus tin" (DMA dis s., Temple University, 2014), ProQuest Dis sertations Publishing.
} 
In this dissertation, Abramova begins by introducing the background and history of jazz traditions in Russia; she also illustrates how the social, cultural, and political atmosphere within which Kapustin composed influenced his musical writings and musical styles. Then, she conducts formal analysis of selected piano works and gives pedagogical recommendations on tempo, articulation, expression, and control, through a comparison of recordings by Kapustin himself and by others.

Another dissertation was written by Ruby Wang, entitled "Fusion of Classic Virtuosity and Jazz Techniques in the Etudes of Nikolai Kapustin: Eight Concert Etudes, Op. 40, and Five Etudes in Different Intervals, Op. 68" (2014, D.M.A. dissertation), which focuses on Kapustin's stylistic features and influences. ${ }^{15}$ It consists of six chapters, as shown below:

1. Introduction

2. Nikolai Girshevich Kapustin

3. Kapustin's Assimilation Of Jazz Styles And Techniques

4. Kapustin's Etude Techniques

5. A Closer Look at Etude Op. 40, No. 1, "Prelude"

6. Conclusion

The first two chapters introduce Nikolai Kapustin's biography and his works, as well as giving background information about the evolution of jazz in Russia. The author gives different perspectives in Chapter Three by providing a brief overview of the jazz vernacular and investigating how Kapustin utilizes these tools in his writing. Chapter Four focuses on the various technical aspects of Kapustin's etudes and the way in which they parallel or differ from etudes by the classical etude composers who influenced him. ${ }^{16}$ The fifth chapter provides detailed harmonic analysis and pedagogic recommendations by examining one etude: Op. 40, No.

\footnotetext{
${ }^{15}$ Ruby Wang, "Fusion ofClas sical Virtuosity and Jazz Techniques in the Etudes of Nikolai Kapustin: 'Eight Concert Etudes,' Op. 40, and 'Five Etudes in Different Intervals,' Op. 68" (DMA diss., University of South Carolina, 2014).

${ }^{16}$ W ang, "Fu sion of Classical Virtuosity," 2.
} 
1 "Prelude." The final chapter presents a conclusion. In this dissertation, the author investigates the fusion of jazz technique and classical virtuosity by presenting both sides and by illustrating how the fusion works through a detailed analysis of the first etude, Prelude, from Op. 40.

The third related dissertation was written by Akane Megumi Okamoto, from the University of Toronto, entitled 'Nicholai Kapustin's Eight Concert Etudes, Op. 40: Reflections on Analysis, Practice, and Performance." ${ }^{17}$ It consists of five chapters, as shown below:

1. Introduction

2. Kapustin's Life, Works, and Approach

3. a) Achieving Mindfulness Through Analysis; b) Analysis of Kapustin's Eight Concert Etudes

4. a) Creating a Healthy and Productive Internal State for Practice; b) Applications to Kapustin's Eight Concert Etudes, Nos. 5-8

5. Mindfulness and Connection to the Instrument

The first two chapters are mainly about Kapustin's life, works, and approach. Then, the third chapter provides formal and harmonic analysis of each etude and the fourth chapter explores selected components from Etudes 5-8 from this set, based on each etude's character, with possible performance implications. The last chapter extends the topic to a discussion focusing on the physical aspect of playing. In this dissertation, each chapter is clearly organized. Chapter 3 provides theoretical analysis, which is the foundation for players to understand the music and translate it into practice. Chapters 4 and 5 provide suggestions for practicing the pieces, both regarding the technical issues from the music and also about the physical aspects that may influence performance. ${ }^{18}$

\section{Periodicals}

\footnotetext{
${ }^{17}$ Akane Okamoto, "Nicholai Kapustin's Eight Concert Etudes, Op. 40: Reflections on Analysis, Practice, and Performance" (PhD dis s., University of Toronto, 2013).

${ }^{18}$ Okamoto, "Kapustin's Eight Concert Etudes," 5.
} 
The American Record Guide (ARG), as a music magazine providing reviews of classical music recordings since 1935, started sharing information on musicians and music events in the US in 1992. There are a few articles, mostly CD reviews, concerning Kapustin's musical works, such as cello pieces or piano pieces. Alan Becker provides a review of one recording, entitled "Kapustin: Eight Concert Etudes; 24 Preludes in Jazz Style". ${ }^{19}$ The recording lasts 75 mins and was performed by Catherine Gordeladze, a German pianist. In the opening, Becker provides a brief educational background about Kapustin, followed by a comparison between Gordeladze and other two pianists, Canadian pianist Marc-André Hamlin and Scottish pianist Steven Osborne, both of whom made recordings of works by Kapustin. Becker thinks that the technical and musical challenges are fully met by all three, while the only difference is that Gordeladze's rendition is slightly slower in tempo and puts more emphasis on the harmonic and lyrical aspects of music writing, while still being enjoyable.

An interview article by Martin Anderson published in the journal Fanfare, entitled "Nikolai Kapustin, Russian Composer of Classical Jazz," 20 was probably one of the first articles or reports introducing Kapustin to the greater public in the world. Through the direct answers by Kapustin via a translator during the interview in London, UK in May, 2000, this article unveils his educational background, including the important piano teachers who had the most influences on him; how he started working on fusing classical music structure and jazz characteristics; how he viewed his own compositional style, especially the role of "improvisation" during his composition; and the increased popularity of his music, which has been performed more frequently on the stages, as well as his preference for recording his own music, rather than performing live on stage for public audiences.

\footnotetext{
${ }^{19}$ Alan Becker, "Guide to Records-Kapustin:24 Preludes in Jazz Style," American Record Guide 74, no. 1 (2011): 147.

${ }^{20}$ Martin Anderson, “Nikolai Kapustin, Russian Composer of Clas sical Jazz,” Fanfare, Sept/Oct. 2000, 93-97.
} 
Another interview article, published in the journal Piano: International Piano Quarterly, was written the same year by Harriet Smith and entitled "Bridging the divide: An interview with Kapustin."21 Like Martin Anderson's interview, this interview was conducted when Kapustin travelled to southeast London to hear his Second Sonata performed by Marc-André Hamelin at Blackheath Music Halls. This article presents the pathways of Kapustin's education which led to his compositional style as the fusion of classical music and jazz idioms; it also discusses Kapustin's advocation of composing at the piano.

${ }^{21}$ Harriet Smith, "Bridging the Divide: An Interview with Kapustin," International Piano Quarterly 4, no. 13 (2000):54-55. 


\section{Chapter III: Biography and Discussion of Works}

\subsection{Biography}

\subsubsection{Early Life and Education}

Nikolai Kapustin was born November 22, 1937, as the second child to Grigory Efimovich Kapustin and Klavdia Nikolaevna Kapustin in a small town, Horlivka, Ukraine. Though his parents were non-musicians, they provided resources for Kapustin and his elder sister to become musicians, or at the very least to have fondness and appreciation for music in general. Kapustin's early musical training was provided by his elder sister Fira's violin teacher, Piotr Ivanovich Vinnichenko, who was primarily a violinist, but also taught piano. ${ }^{22}$ Since the boy showed considerable talent at age 12, he was referred to Lubov' Frantsuzova (1877-1966) ${ }^{23}$ at the St. Petersburg Conservatory for more formal music learning. During his three years of study under Frantsuzova, Kapustin not only laid a solid foundation in piano performance, but also expanded his horizons in composition, including making his first attempt to compose a piano sonata at age 13. This sonata is in a "traditional Russian-Ukrainian Style" 24 and it further consolidates a clear path for pursuing his musical career.

At age 15, Kapustin passed the entrance exam of Moscow Music College and studied with Averlian Rubakh (1885-1960). Rubakh had been a student of Felix Blumenfeld (1863-1931), whose students included Vladimir Horowitz (1903-1989), Simon Barere (1896-1951), and Alexander Tsfasman (1906-1971). Tsfasman was an important figure in Soviet jazz from the

\footnotetext{
${ }^{22}$ Tyulkova, "Clas sical and Jazz Influences," 10.

${ }^{23}$ Frantsuzova graduated from the St. Peters burg Conservatory as a student of Samuil Maikapar (1867-1938), who was a Russian Romantic composer, pianist, and professor of music at the St. Petersburg Conserv atory (1910-1930), and an educator.

${ }^{24}$ Jonathan Roberts, "Classical Jazz: The Life and Musical Innovations of Nikolai Kapustin" (DMA dis s., University of Alabama, 2013), 17.
} 
period of the mid-1920s until the late 1960s and his ideas about jazz writing had a significant influence on Kapustin. Kapustin said, "We (pianists) liked Tsfasman for his elegance and outgoing style and his perfect finger technique.”25 Kapustin also performed Tsfasman's piano concerto with the Radio Orchestra in the early 1970 s. ${ }^{26}$ In an interview with Fanfare's Martin Anderson, Kapustin commented on his teacher:

Rubakh was my first serious teacher; that was in Moscow. For four years I studied so hard that I feelI was at the same level, so these four years were critical for me. ${ }^{27}$

Upon graduation from Moscow Music College, Kapustin was encouraged by Rubakh to continue his study at the Moscow Conservatory, and he was admitted at the age of 19 . In the Moscow Conservatory, he studied with Alexander Goldenwiser. As revealed in an interview article by Martin Anderson on the Fanfare, he recalled the scene when he first met Goldenwiser:

It was he (Rubbakh) whotook me to (Alexander) Golden wiser. I played him the Liszt Don GiovanniFantasy; he liked how I played and asked Rubbakh, "where did you find such a pianist?"28

Alexander Goldenwiser (1875-1961) was a Russian pianist, teacher and composer. He graduated from the Moscow Conservatory and studied piano with Alexander Ziloti and later with Paul Pabst. He studied composition and counterpoint together with Anton Arensky, IppolitovIvanov, and Sergei Taneyev, all of whom were former students of Tchaikovsky. ${ }^{29}$ He was a close friend of Sergey Rachmaninov, Alexander Scriabin and Russian writer Leo Tolstoy. As a piano professor at the Moscow Conservatory for 55 years, he was the teacher of many great Russian pianists in the 20th century. Kapustin mentioned his teacher during an interview:

I went to him(Goldenwiser) when I was 18 . He was a very interesting person-he remembered Rachmaninov and Medtner, so it was very interesting to speak with

\footnotetext{
${ }^{25}$ Mann, "Red, White, and Blue Notes," 33.

${ }^{26}$ Sus annah Steele, "Nikolai Kapustin's 'Ten Bagatelles,' Op. 59" (DMA diss., the University of North Carolina at Greensboro, 2013), 3.

${ }^{27}$ Anderson, "Russian Composer of Clas sical Jazz," 94.

${ }^{28}$ Anderson, "Russian Composer of Clas sical Jazz," 94.

${ }^{29}$ Smith, "Bridging the Divide," 33.
} 
him..... He told me what they said, how things happened, things you will never read in books about these composers. That was the main interest. ${ }^{30}$

However, as one of the last students of Goldenwiser, Kapustin thought that what he learned from him was limited because the teacher was too old then (already 81). Goldenweiser passed away in 1961, which was also the year that Kapustin graduated from the Moscow Conservatory with a recital program including the Liszt B-minor Sonata and Beethoven's Sonata Op. 54. ${ }^{31}$

\subsubsection{Encountering Jazz}

Kapustin's music education was quite traditional. Jazz became deeply rooted in his life, but that exploration occurred mostly outside his academic study. This was primarily due to the historic situation, as the development of jazz in Russia was not a smooth process. Especially during the wartime periods-World War I (1914 -1918), the Russian Civil War (1917-1922), or World War II (1939-1945) — jazz arising from popular musical culture was considered less appropriate than revolutionary and patriotic songs, music that represents proletarian culture. ${ }^{32}$

The first jazz band in Russia was organized in 1922 by Valentin Parnakh (1891-1951), a Russian poet and musician known as a founding father of Soviet jazz. ${ }^{33}$ The first-generation Soviet jazz musicians learned how to play jazz from the recordings and music that were sent from the West, and jazz music deve loped rapidly in Russia during the late 1920s and early 1930s. However, in Russia's repressive political environment after World War II, jazz was prohibited and musicians who actively played jazz faced accusations and arrests; this situation was not relieved until Stalin's death in $1953 .{ }^{34}$

\footnotetext{
${ }^{30}$ Anderson, "Russian Composer of Clas sical Jazz," 94.

${ }^{31}$ Smith, "Bridging the Divide," 54.

${ }^{32}$ Abramova, "Synthesis of Jazzand Classical," 6.

${ }^{33}$ Abramova, "Synthesis of Jazzand Classical," 7.

${ }^{34}$ Abramova, "Synthesis of Jazzand Classical," 13-14.
} 
After the thaw in the post-Stalin era, many talented musicians emerged with new jazz music works. American jazz groups and other musicians were allowed to visit the Soviet Union during the 1960s. However, international musical communication was still restricted and Soviet musicians at that time were not free to travel abroad. It was relatively late that jazz education was set up as an official course at the conservatory level. Rostov State Conservatory finally established a jazz department in 1982 and Moscow Conservatory began offering jazz improvisation as an official course in $1994 .{ }^{35}$

Kapustin initially gained interest in jazz when he was studying in Moscow Music College, where he met his classmate and good friend, Andrei Mikhalkov-Konchalovsky, son of a famous dramatic poet, Sergei Mikhalkov. ${ }^{36}$ Due to the poor living conditions at the college, Kapustin was invited to live in Andrei's home, where they started to listen to jazz music and fell in love with it. Kapustin stated:

I was living in their house for a few years like an adopted son. That's how we first started to become interested in jazz music, listening at night to the radio station "Voice of America."

He also wrote:

At first my friends and I could hear jazz only on the radio. I do not remember which jazz artist I heard first. It could be Glenn Miller or Louis Armstrong. ${ }^{38}$

Thus, his initial training in jazz primarily consisted of listening to recordings that were

broadcast on the radio at that time. He described his experience with jazz this way:

As soon as I first heard it, I started playing jazz. I understood it was something for me. I understood that I had to combine the two styles...... When I took it to my friends they were very excited, and so I understood that I was on the right direction. I never tried to be a real jazz pianist but Ihad to do it because of the composing. ${ }^{39}$

\footnotetext{
${ }^{35}$ Abramova, "Synthesis of Jazzand Classical," 16.

${ }^{36}$ Tyulkova, "Clas sical and Jazz Influences," 13.

${ }^{37}$ Tyulkova, "Clas sical and Jazz Influences," 14.

${ }^{38}$ Mann, "Red, White, and Blue Notes," 28.

${ }^{39}$ Anderson, "Russian Composer of Clas sical Jazz," 94.
} 
During his study at Moscow Music College, Kapustin organized a jazz quintet and performed monthly in a Moscow restaurant named "National," 40 where their music was wellappreciated. Some of their music was recorded and broadcast by Voice of America. He reminisced:

I joined a jazz combo and we played once a month in a restaurant--- it was a restaurant for very rich foreigners. Americans would come to this restaurant, and one day they came and recorded us. Very soon Voice of America broadcast that recording. ${ }^{41}$

While studying at the Moscow Conservatory, he continued to work on jazz composition and play jazz music with different groups - his own quintet and Yuri Saulsky’s Central Artists'

Club big band. ${ }^{42}$ In 1957, the Sixth World Festival of Youth and Students was held in Moscow. This important international gathering not only marked a historic event in the development of Russian jazz, but also had special significance for Kapustin himself. In this festival, he performed his own piece, Concertino for Piano and Orchestra, Op. 1, which was a key turning point of his career as a composer. He stated:

In 1957 there was an international festival of youth. It wasn't just about music, but many things, and people came fromall over the world. Unfortunately, it was a big communis tic mes s! I played my Op. 1 Concertino for piano and orchestra - It was the first time I'd played one of my own pieces in public....... It was nothing very serious. It's a very jazzy piece. ${ }^{43}$

\subsubsection{Career and Later Life}

After he graduated from the Conservatory, Kapustin joined Lundstrem's Big Band, participating from 1961 to 1972 , touring the Soviet Union and other countries with the group. Lundstrem's Big Band was founded in 1934 in the Chinese city of Harbin by the legendary Oleg Lundstrem, a member of the large Russian colony living in that city. The band moved back to

\footnotetext{
${ }^{40}$ Tyulkova, "Clas sical and Jazz Influences," 14.

${ }^{41}$ Anderson, "Russian Composer of Classical Jazz," 94.

${ }^{42}$ Mark Peters, “A Study of Nikolai Kapustin's Sonata No. 12, Op. 102: A Contemporary Jazz Sonata in Two Movements" (DMA dis s., West Virginia University, 2017), 16.

${ }^{43}$ Smith, "Bridging the Divide," 54.
} 
Russia after World War II (1948) and settled in Moscow in 1956. ${ }^{44}$ It was considered to be a top jazz band in Russia at that time. In Lundstrem's Big Band, Kapustin took on multiple roles, including composing music for the Big Band, orchestrating the pieces to be performed, and performing as Big Band pianist. He reminisced during an interview,

Eleven years of work with Lundstrembecame my "Second Conservatory": a large amount of arranging, performances, and ear-training experience. We wrote down all the big-band parts from the tape. We were big en thusiasts. It was a school more serious than Conservatory...... Mostly it was classical jazz - Count Basie, Duke Ellington. Even if we were performing Soviet songs, orchestral accompaniment still was in the style of Count Basie. ${ }^{45}$

The music works that he composed during this time were mainly for orchestra and big band.

Here is a list of these compositions:

- Op. 2: Concerto for piano and orchestra No. 1 (1961)

- Op. 3: Variations for piano and big-band (1962)

- Op. 4: Chorale and Fugue for orchestra (1962)

- Op. 5: Piece for trumpet and orchestra (1962)

- Op. 6: "Rose-Marie", fantasia for orchestra (1963)

- Op. 7: Fantasia on three children's songs for orchestra (1963)

- Op. 8: Toccata for piano and orchestra (1964)

- Op. 9: "The Trial", piece for orchestra (1966)

- Op. 10: "Big Band Sounds (The Sounds of Big-Band)" for orchestra

- Op. 11: "Estacade" for big band (1966)

- Op. 12: "Aquarium-Blues" for big-band (1967)

- Op. 13: Intermezzo for piano and orchestra (1968)

- Op. 14: Concerto for piano and orchestra No. 2 (1974)

- Op. 15: "The Forest Story" for orchestra (1972)

- Op. 16: Nocturne in G major for piano and orchestra (1972)

- Op. 17: Three pieces for orchestra (1972)

The work in Lundstrom's Big Band gave him not only advancement of his career, but also the fate of finding his life partner. Kapustin met Anna Baranovskaya in Novokuznetsk, Siberia, during his performance tours with Lundstrom's Big Band in the late 1960's; they married in

\footnotetext{
${ }^{44}$ Abramova, "Synthesis of Jazzand Classical," 14.

${ }^{45}$ Tyulkova, "Clas sical and Jazz Influences," 17.
} 
1969.46 Kapustin and his wife had their first child, Anton Nikolayevich Kapustin, in 1971; Anton eventually became a physicist in the United States. To spend more time with his family, Kapustin left Lundstrom's band in 1972.47 Then he joined the Boris Karamishev "Blue Screen" Orchestra in Moscow, centering on broadcasting music through live television and radio, and also recording works by Soviet composers. ${ }^{48}$ The Orchestra also toured in the Soviet Union. Five years later, Kapustin joined the State Cinematography Symphony Orchestra, which focused on recording music for the cinema from 1977 to 1984. During this period, in 1978, Kapustin and his wife had their second son, Pavel Kapustin, who eventually became an economist in Moscow.

Kapustin performed his Piano Concerto No. 2, Op. 14, in Tchaikovsky Concert Hall in 1980. After that, he focused his career on composing rather than performing.

The most productive period in my life beg an when I stopped playing with orchestra. So I became completely free as a composer only in 1984, although even before I composed quite a few pieces. ${ }^{49}$

Kapustin became a very productive composer, with new music works being written and published every year, while his compositional styles evolved along the way. Specifically, since 1984, the genre of his compositions gradually shifted from orchestra works to mostly piano works and a few others including chamber works, quartets, quintets, and concerti.

Though he has produced many compositions, Kapustin's music has not gained the popularity that it deserves, mostly because he has spent most of his life in Russia, doesn't like international travel, and is not interested in self-promotion. In 2000, pianist Marc-André Hamelin chose to perform Kapustin's Second Sonata during his recital tours around the world, bringing huge public and media attention to Kapustin's music. An interview with Fanfare's Martin Anderson provides this description:

\footnotetext{
${ }^{46}$ Peters, "A Study of Nikolai Kapustin's Sonata," 17.

47 Tyulkova, "Clas sical and Jazz Influences," 18.

${ }^{48}$ Peters, "A Study of Nikolai Kapus tin's Sonata," 17.

${ }^{49}$ Abramova, "Synthesis of Jazzand Classical," 2.
} 
Earlier this year (2000), in May, Hamelin gave the Western premiere of the Second Sonata at a "Hamelin weekend" at Blackheath Concert Halls in southeast London, and Kapustin made the journey from Moscow for the occasion - not an easy decision, I imagine, since he does not like flying, and the trip meant three days in a train across the length of Europe. ${ }^{50}$

During his London trip to attend the recital, Kapustin also visited the "Kapustin Society," which was founded and organized by Jan Hoare and which became the main source for obtaining Kapustin's music. In addition, he accepted a few interviews with English journals and newspapers, including interviews with Martin Anderson and Leslie De'Ath. Kapustin was grateful for his warm reception in London. Later he dedicated Piano Sonata No. 11, Op. 101 to London; this work was also given the name "Twickenham," for a borough in the southwest of London. ${ }^{51}$

Kapustin has quickly become more widely known since around 2000; his compositions are spreading quickly as well. In recent decades, his music has not only been performed by many musicians, but also has been recorded by more and more artists. Kapustin himself also recorded solo albums which were released between 1986 and 2009 (concert recordings with Alexander Zagorinsky), especially a series of recordings titled "Kapustin Plays Kapustin.” He stated, "I don’t like to play on stage, but I do like to record." ${ }_{52}$

On November 21, 2016, a concert entitled "Nikolai Kapustin's Masterpieces-Dedicated to Kapustin's 79th Birthday" concert was given at Moscow's House of Music, with performances by Igor Butman and the Moscow Jazz Orchestra; by Vladimir Spivakov and the Moscow Virtuosi Chamber Orchestra; and by pianist $\mathrm{A} \mathrm{Bu}$, a young Chinese jazz pianist and composer. The works performed included Variations, Op. 3; Big Band Sounds, Op. 10; Etude, Op. 19; Minuet, Op. 21; Day Break, Op. 26; Variations, Op. 41; Andante, Op. 58, and two Piano Concertos (No. 2, Op. 14 and No. 4, Op. 56). The following year, on November 30, 2017, a concert celebrating Kapustin's

\footnotetext{
${ }^{50}$ Anderson, "Russian Composer of Clas sical Jazz," 93.

${ }^{51}$ Tyulkova, "Classical and Jazz Influences," 20.

${ }^{52}$ Anderson, "Russian Composer of Classical Jazz," 97.
} 
80th birthday took place in the Great Hall of the Moscow Conservatory. Currently, Kapustin continues his compositional work in Moscow. As of this writing, his latest work, entitled "The Moon Rainbow," is a solo piano piece that was composed in 2016.

\subsection{Overview of Kapustin's Piano Works}

Kapustin's output includes 161 opus numbers to date. Most of his works are written for piano. Representative piano works include 20 piano sonatas, a set of 24 preludes and fugues, two suites, ten bagatelles, six piano concertos, numerous etudes, preludes, variations, impromptus and more.

The first piano solo work by Kapustin is Daybreak, Op. 26 (1976). It is a short piece in a swinging jazz style. During the same year, Kapustin arranged an orchestral version of this work. In the following year, he wrote Suite in Old Style, Op. 28, in five movements: Allemande, Gavotte, Sarabande, Bourrée and Gigue. The names of the movements in Suite in Old Style are all taken from Baroque dances. While employing the traditional binary form, Kapustin writes these dances in his own unique style, using lush jazz harmonies. Toccatina, Op. 36, written in 1983, is a short perpetual-motion piece, in which the jazz harmonic colors combine with typical toccata characteristics: repeated notes, percussive sound, rapid motion, and technical virtuosity.

Since 1984, Kapustin has devoted most of his compositional energy to writing piano works, which occupy the most important position in his catalog of works. Among these piano pieces, 20 piano sonatas are representative of his large-scale works. The first two sonatas appeared in 1984 and 1989, respectively, followed by eight sonatas (No. 3-10) in the 1990s, another eight sonatas 
(No. 11-18) in the 2000s, and the last two sonatas in 2011.53 Among the 20 sonatas, the number of individual movements varies:

Three in one movement (No. 3, 8, 15), One in two movements (No. 12), Eleven in three movements (No. 4, 5, 6, 9, 10,11, 14, 16, 17, 18, 20), and Five in four movements (No. 1, 2, 7, 13, 19).

Three piano sonatas are titled or given nicknames: Sonata No. 1 ("Sonata-Fantasia"), Op. 39; Sonata No. 11 "Twickenham”, Op. 101; and Sonata No. 15 ("Fantasia quasi Sonata"), Op. 127. Only two piano sonatas bear dedications to someone: Sonata No. 17, Op. 134, is written for Italian pianist Vito Reibaldi, while Sonata No. 19, Op. 143, is dedicated to the Russian pianist Alexei Volodin. ${ }^{54}$

In contrast to the virtuoso demands of the 20 piano sonatas, the Sonatina, Op. 100, composed in 2000, is one of the few pieces by Kapustin that are technically suitable for an amateur to play well. It is a short, one-movement work in thin texture, cast in sonata-allegro form.

Variations, Op. 41, written in 1984, is a compact work that lasts about seven minutes. It features a theme and variations based on the opening solo bassoon melody in Stravinsky's The Rite of Spring. ${ }^{55}$ The double bar lines in the score indicate the beginning of a new variation or an interlude/transitional section. Almost all the variations feature an abundance of jazz elements. Only the Larghetto variation in C-sharp minor lacks jazz harmonic and rhythmic language; instead it is more lyrical, in bel canto style. The final variation is extended by a short coda that brings the sense of extreme excitement.

\footnotetext{
${ }^{53}$ Tyulkova, "Classical and Jazz Influences," 31-37.

${ }^{54}$ Tyulkova, "Classical and Jazz Influences," 37.

${ }^{55}$ Ryan T. Kelly, “The Big Band and the Piano: Nikolai Kapus tin's Variations Op. 41” (DMA diss., Manhattan School of Music, 2016), 35.
} 
Kapustin has also written many small-scale works. The 24 Preludes, Op. 53, composed in 1988, is a set of short pieces that reflect in their tonal organization the key scheme of the Chopin Preludes, Op. 28, covering all the major and minor keys, presented in circle-of-fifths order, with each major key being followed by its relative-minor key (C-a, G-e, D-b, A-f\#, E-c\#, etc.). Each of Kapustin's preludes conveys a distinctive mood and the set displays a wide variety of jazz styles:

Blues (No. 11);

Ballad (No. 5, 9);

Jazz waltz (No. 18);

Swing (No. 17, 19);

Jazz funk (No. 7, 12); and a sort of

"Take Five" Latin jazz style (No. 13). ${ }^{56}$

These Preludes reveal traditional formal structures, such as ternary form or rondo form.

Most pieces start with a new theme and then offer contrasting or quasi-improvisational material. Several preludes do not have contrasting sections and instead are structured around one theme or motive, ${ }^{57}$ exhibiting monothematic form (A A'), such as No. 3 in $G$ major. Most pieces are technically difficult, especially the longer and more complex preludes, such as No. 1 in C major and No. 23 in F major.

Another set of Twenty-Four Preludes and Fugues, Op. 82 was written in 1997, fusing jazz harmonic idiom with classical contrapuntal techniques. Though modeled on J. S. Bach's WellTempered Clavier, the key organization in Op. 82 is unusual: the major alternates with unrelated minor-major keys in the order of the circle of fifths, presented counterclockwise (in the flat direction), while the minor ones that follow are a major third below (C-g\#, F-c\#, Bb-f\#.....G-

\footnotetext{
${ }^{56}$ Nikolai Kapustin, "Twenty-Four Preludes, Op. 53” (Moscow: A-RAM, 2004), 2.

${ }^{57}$ Randall J. Creighton, “A Man of Two Worlds: Clas sical and Jazz Influences in Nikolai Kapus tin's Twenty-Four Preludes, Op. 53” (DMA dis s., The University of Arizona, 2009), 187.
} 
eb) ${ }^{58}$ In Op. 82, only one fugue is in two voices (Fugue XIII in c minor) and one in five voices

(Fugue XIX in A major). The other fugues use either three or four voices. There is a motivic connection between prelude and fugue, in that each fugue is composed by following the motif of the preceding prelude.

Ten Bagatelles, Op. 5, composed in 1991, are all short pieces and written in a great fusion of jazz and classical style, such as ragtime, impressionism, cool jazz, swing, improvisation, and bebop throughout the opus. ${ }^{59}$ The structures used in these bagatelles are based on the classical formal design, such as binary, ternary, or ternary with coda. The Kapustin bagatelles feature a rich mix of jazz elements, such as swing rhythms, syncopation, blue notes, extended harmony, and improvisation. Among these ten pieces, three of them (No. 2, 5, 8) are melancholy and expressive in character. The remaining seven (No. 1, 3, 4, 6, 7, 9, 10) are more vibrant and energetic in character. ${ }^{60}$ Bagatelle No. 6 includes special touches of humor and partially quotes Chopin's Etude in c minor ("Revolutionary") near the end of the piece. ${ }^{61}$

Kapustin wrote three sets of etudes: The Eight Concert Etudes, Op. 40 (1984), Three etudes, Op. 67 (1991), and Five Etudes in Different Intervals, Op. 68 (1992); one more recent etude is Etude Courte mais Transcendante pourpiano, Op. 149 (2013). The Three Etudes, Op. 67, include No. 1 Glissandi, No. 2 Ripetizione and No. 3 Grappole. The technical difficulty explored in each is fairly obvious from its title and each focuses on a single problem: glissando, repeated notes and tone clusters. Five Etudes in Different Intervals, Op. 68, is influenced by Debussy's Twelve Etudes, some of which also explore a compositional approach using specific intervals.

\footnotetext{
${ }^{58}$ Creighton, "A Man of Two Worlds," 34.

${ }^{59}$ Sekyeong Seong, "Bagatelles No. 6 and No. 8, Op. 59 by Nikolai Kapustin:Background, Analysis, and Performance Guideline” (DMA diss., The Ohio State University, 2015), 52.

${ }^{60}$ Seong, "Bagatelles No. 6," 54.

${ }^{61}$ Seong, "Bagatelles No. 6," 58.
} 
In Op. 68, Etude No. 1 is a study in minor seconds and major sevenths, using chromatic seconds and disjunct, syncopated sevenths. Etude No. 2 is a study in fourths and fifths, using parallel fourths and fifths. Etude No. 3 is a study in thirds and sixths, employing double thirds and parallel, syncopated sixths. Etude No. 4 is a study in major seconds, which are chromatic and syncopated. Etude No. 5 is a study in octaves, with many parallel, disjunct and broken octaves.

Etude Courte mais Transcendante pourpiano, Op. 149, is a short piece with a French title. It is freer in structure and could be divided into nine sections, including an eight-bar introduction and an eight-bar coda at the end. ${ }^{62}$ The double bar lines in the score indicate the beginning of a new section. A wide range of jazz techniques appears in the etude, such as stride bass and elaborate syncopations. The etude contains a variety of technical problems, such as skips, double notes, octaves, chromatic figuration, and passagework in cross-rhythms. The Eight Concert Etudes, Op. 40 (1984), among the most frequently performed Kapustin pieces, will be given more specific analysis in chapter $\mathrm{V}$.

Kapustin also wrote a number of miscellaneous works, most of which are single movements with descriptive titles, such as Nothing to Lose, Op. 119 (2004); Nobody is Perfect, Op. 151 (2013); A Pianist in Jeopardy, Op. 152 (2013); Rainy Weather, Op. 159 (2015); and The Moon Rainbow, Op. 161 (2016). Some of them are arrangements of famous jazz tunes, such as Paraphrase on Ary Barroso's Aquarela do Brasil, Op. 118 (2003) and Paraphrase on Kenny Dorham's “Blue Bossa," Op. 123 (2004). Six Little Pieces, Op. 133 (2007) is one of the few works that involve not too much technical difficulty. These miniatures are short and display a thin texture; they are also playable with small hands, since the intervals in each hand do not

\footnotetext{
${ }^{62}$ Qingqing Ye, “Nikolai Kapustin's Solo Piano Works 2007-2013: A Recording and Performance Guide” (DMA diss., Arizona State University, 2018), 66.
} 
exceed an octave. ${ }^{63}$ These pieces can allow intermediate to early advanced players to explore Kapustin's music, approaching his more difficult scores when they become more capable and confident.

Besides his compositions for solo piano, Kapustin also composed six piano concertos, each of which has two versions - an arrangement for piano and orchestra or band, and an arrangement for two pianos. As jazz-influenced piano concertos, most of them follow the classical concerto structure in three movements, with the exception of Concerto No. 1 (revised $2^{\text {nd }}$ edition in 2012) and Concerto No. 4, Op. 56 (1990), which are composed in one movement.

Kapustin also produced several works for four hands or two pianos, such as Triptych, Op. 145 (two pianos), and Capriccio, Op. 146 (four hands), both of which were composed in 2012. Paraphrase on Dizzy Gillespie's "Manteca"for Two Pianos, Op. 129 (2006), is another example that uses a famous jazz tune as source material for an arrangement.

Kapustin's piano pieces have been published by various companies over the years. Early in his career, publishers in Russia, United Kingdom and Japan issued Kapustin's sheet music. In the Russian edition, A-Ram (Moscow), each publication includes a short biography of the composer and a brief description of the music. The UK edition is owned by MUST (Music Trading Company, managed by Timothy R. Gill). The Japanese edition, by Prhythm (Affairs Co. LTD, Tokyo), includes program notes in Russian, Japanese and English, edited by Masahiro Kawakami, a Japanese pianist and Associate Professor at the Tokyo College of Music. Kawakami is dedicated to performing Kapustin's works and also to conducting research on them. In 2009, Nikolai Kapustin dedicated two piano solo works, Good Intention, Op. 137, and Sleight of Hand, Op. 138, to Kawakami, who not only made recordings of Kapustin's piano solo works and chamber works, but also edited scholarly publications of piano works by Kapustin for Zen-

\footnotetext{
${ }^{63}$ Ye, "Solo Piano Works," 17.
} 
on, a Japanese publishing company. It is worth mentioning that Zen-on published Kapustin's Eight Concert Etudes, Op. 40, edited by Kawakami and including his Japanese-language performance notes and comments as well as fingerings. Since 2014, the only valid publisher for Kapustin's music is Schott Music (Germany). 


\section{Chapter IV: A Brief History of Etudes}

\subsection{Definition and Background of the Genre}

Étude is a French word deriving from the Latin root "studium" 64 and literally meaning "study" in English. As it developed and evolved throughout the centuries, the etude has not only served for technical exercises, but also as concert repertoire that beautifully represents composers' personal styles. The music term is defined from the Harvard Dictionary of Music as follows:

A piece designed to aid the student of an instrument in the development of his mechanical and technical ability. An etude is usually devoted entirely to one of the special problems of instrumental technique, such as scales, arpeggios, octaves, double stops, trills, etc. While etudes are written in the form of a complete piece, finger exercises are short formulae which have to be repeated many times, either on the same pitch, or moving through the degrees of the scales.... ${ }^{65}$

A History of Western Music (Seventh Edition) defines the genre this way:

An instrumental piece designed to develop a particular skill or performing technique. Certain nineteenth-century etudes that contained significant artis tic content and were played in concert were called concert etudes. ${ }^{66}$

In keyboard literature, the etude as a genre emerged in the early $19^{\text {th }}$ century. However, the origins of this genre can be traced back to the Baroque period. This kind of music was mainly written for didactic purposes. ${ }^{67}$ Based on the popular genres of keyboard music in the Baroque era, these pedagogical pieces usually had titles with the meaning of "exercise" (French exercice, German Übung, Italian essercize), "study” (French étude, German Studie, Italian Studio) and

\footnotetext{
64 “Merriam-Webster Dictionary," accessed Apr. 06, 2019, https://www.merriamwebster.com/dictionary/study\#etymology/.

${ }^{65}$ Will Apel, Harvard Dictionary of Music. (Cambridge, Mass.: Harvard University Pres s, 1955), 249.

${ }^{66}$ J. Peter Burkholder, Donald Jay Grout, and Claude V. Palisca. A History of Western Music, $7^{\text {th }}$ edition. (New York: W.W. Norton, 2005).

${ }^{67}$ Angelina Ngan-chu Au, "The Piano Etude in the Nineteenth Century: From the Acquisition of Facility to Demonstration of Virtuosity"(DMA diss., University of Cincinnati, 1999), 2.
} 
"lesson" (French leçon, Italian lezione). ${ }^{68}$ The term "study" was used to describe pieces for practical purpose, "exercise" was used to describe individual pieces, and "lesson" was used to describe a keyboard suite or individual movement. ${ }^{69}$ Before the pianoforte appeared at the end of the first quarter of the eighteenth century, many didactic pieces were written for the harpsichord and clavichord.

Henry Purcell (1659-1695), the greatest English composer in the middle Baroque era, composed A Choice Collection of Lessons for the Harpsichord or Spinet that includes dance suites and miscellaneous pieces. ${ }^{70}$ The left-hand fingering in this edition is notated differently from our current way: The numbers increase from the left, with the little finger of the left hand being the first and the thumb being the fifth. The notation of right-hand fingering is the same as our current practice, with the thumb called "1" and the little finger "5."

In 1717, François Couperin (1668-1733), a French Baroque composer, wrote the influential treatise L'art de toucher le clavecin (The Art of Playing the Harpsichord), which gives suggestions for fingerings, ornamentation, and other features of keyboard technique, along with eight preludes. ${ }^{71}$

Jean-Philippe Rameau (1683-1764), a French composer and music theorist of the eighteenth century, wrote Pièces de clavecin avec une méthode pour la mecanique des doigts (Pieces for Harpsichord with a Method for Finger Technique) in 1724. ${ }^{72}$ It contains two sets of pieces: The first set includes several dance movements and two descriptive pieces; the second set has five rondeaus, one minuet and several descriptive pieces.

\footnotetext{
${ }^{68}$ Peters, "A Study of Nikolai Kapustin's Sonata," 18.

${ }^{69}$ Peter Felix Ganz, "The Development of the Etude for Pianoforte" (PhD dis s., Northwestern University, 1960), 910.

${ }^{70}$ Stewart Gordon, A History of Keyboard Literature. (New York: Schirmer, 1996), 42.

${ }^{71}$ Gordon, "A His tory of Keyboard Literature," 71.

${ }^{72}$ Gordon, "A His tory of Keyboard Literature," 72.
} 
Domenico Scarlatti (1685-1757), an outstanding Italian keyboard composer, wrote more than 550 keyboard works as teaching pieces for his royal student Maria Barbara. Thirty of them were collected and published as Essercizi per Gravicembalo (Exercises for the Harpsichord) in 1738. ${ }^{73}$ These "exercises" are one-movement sonatas arranged in binary form, featuring hand crossing, repeated notes, wide skips, and extended trills.

Johann Sebastian Bach (1685-1750), a German composer and performer in the Baroque period, wrote many works as teaching pieces for members of his family and his students, ranging from relatively easy teaching pieces to music works that require mature technical control and expressive flexibility. ${ }^{74}$ In 1720 , Bach wrote Klavierbüchlein for his oldest son Wilhelm Friedemann as study material. Arranged in order of difficulty levels, it has fifteen two-part inventions, fourteen of the three-part inventions, seventeen preludes (which were also used as parts of the Well-Tempered Clavier) and miscellaneous pieces. Notenbüchleinfür Anna Magdalena Bach (Notebook for Anna Magdalena Bach) includes two collections that were successively written in 1722 and 1725 for his second wife. ${ }^{75}$ Besides the pieces written by Bach himself, some pieces by other composers, such as Francois Couperin, are also included. Most of these works are short keyboard pieces, with a few vocal pieces included, such as five "French" suites in the 1722 notebook and, in the 1725 notebook, two partitas and the first prelude from the first volume of the Well-Tempered Clavier. Klavierïbung (keyboard exercise) consists of four volumes that were published during Bach's lifetime. It includes his main works written for harpsichord and also for organ, such as six partitas in Klavierübung $I$, and his lengthy and difficult Goldberg Variations in Klavierübung IV.

\footnotetext{
${ }^{73}$ Gordon, "A His tory of Keyboard Literature," 75.

${ }^{74}$ Gordon, "A His tory of Keyboard Literature," 57.

${ }^{75}$ Gordon, "A His tory of Keyboard Literature," 59.
} 
Didactic pieces such as these span a wide variety of musical genres and styles of that time, such as preludes and short dance movements. The pieces composed for studies, lessons, and other didactic instrumental purposes before the 19th century are diversified with no established genres. While technique training is not the ultimate goal, these pedagogical works have enormous artistic value, applying technical material and musical elements to achieve specific technical training purposes.

\subsection{Ge nre Emergence and Early Etudes}

As piano-making flourished, the time period during the late eighteenth and early nineteenth centuries was characterized by rapid development of the fortepiano. With improved construction of the keyboard and other parts, the quality and volume of the sounds changed dramatically and the piano gradually replaced the harpsichord. These upgrades brought composers more options and opportunities to exploit or develop piano techniques in their music, such as double notes, octaves, arpeggios, scalar patterns and so on. With the growing number of professional pianists and also of amateurs from the middle class, the importance of and need for instruction books providing technical training significantly increased and the word étude emerged as a genre in the early 19th century. Composers frequently grouped études into collections, with each piece focusing on a specific technical problem.

Johann Baptist Cramer (1771-1838), a German-born English composer and pianist, wrote the earliest major collection of teaching pieces for the pianoforte-Studio per il pianoforte, Op. 50, which contains 84 etudes. ${ }^{76}$ It was successively published in 1804 and 1810 in two books, each containing 42 etudes; in some later editions it was published in four books. These etudes

\footnotetext{
${ }^{76}$ Gordon, “A His tory of Keyboard Literature,” 204.
} 
vary in length, use keys with three accidentals or less, and focus on improving right-hand technique rather than left hand.

Muzio Clementi (1752-1832), an Italian-born English composer, pianist and pedagogue, wrote his Gradus ad Parnassum (Steps Toward Parnassus) in 1817. ${ }^{77}$ This is a collection of 100 miscellaneous pieces, such as preludes, canons, and sonata-like movements. But most of them are etude-like exercises that focus on a specific technical problem including double notes, arpeggios, repeated notes, ornaments with skips and so on.

Johann Ne pomuk Hummel (1778-1837), an Austrian composer and virtuoso pianist, wrote a set of 24 Etudes, Op. 125, in 1833. It is arranged in the circle of fifths with each majorkey etude followed by an etude in the parallel minor key (C-c, G-g, D-d......F-f). ${ }^{78}$ Training both hands equally, these etudes are varied in style and tempo, such as French-overture style in No. 4 and Bach-influenced style in No. 6 and No. $24 .{ }^{79}$ These etudes cover many kinds of technical issues, such as crossing hands, trills, rapid scales, broken octaves and repeated notes.

Carl Czerny (1791-1857), an Austrian pianist, composer and teacher, was well known for his pedagogical works. As a prolific composer of technical studies, he wrote over 8,000 etudes ranging from relatively easy to advanced level. ${ }^{80}$ The best known collections include: 100 Progressive Studies for the Piano, Op. 139; 125 Exercises for Passage-Playing, Op. 261; The School of Velocity, Op. 299; 40 Daily Studies, Op. 337; Practical Method for Beginners, Op. 599; Preliminary School of Finger Dexterity, Op. 636; Studies for the Left Hand, Op. 718; The Art of Finger Dexterity, Op. 740; Five-Finger Studies, Op. 777; 160 Eight-Measure Exercises, Op. 821; The Little Pianist, Op. 823; and 30 New Studies in Technique, Op. 849. Among these collections,

\footnotetext{
${ }^{77}$ Gordon, "A History of Keyboard Literature," 202.

${ }^{78}$ Gordon, "A History of Keyboard Literature," 206.

${ }^{79}$ Sun-Im Cho, "Johann Nepomuk Hummel's Piano Etudes, Op. 125: A Pedagogical Analy sis" (DMA dis s., The City University of New York, 2012), 24.

${ }^{80}$ Gordon, “A His tory of Keyboard Literature,” 211.
} 
four collections are widely used by teachers and many followed the classic series: Opp. 599, 849, 299, and 740, in increasing order of difficulty. The Art of Finger Dexterity, Op. 740, includes 50 etudes in very advanced level. The training purpose of each etude is well defined, as shown in its subtitle, and focuses on a certain technical aspect of the keyboard. These effective showy pieces are great for building up technique and are often chosen as supplementary materials to provide a pathway toward more virtuosic concert pieces, such as Chopin's etudes.

Other important collections of etudes at this time include Étude contenant 50 Exercices de différents genres, Op. 78, by Daniel Steibelt (1765-1825); Methode de Piano, contenant 50 Exercices doigtées, Op. 56, by Joseph Wölfl (1773-1812); and 12 Etüden, Op. 12; 15 neue Etüden, Op. 22; and two single etudes, Op. 30 and 41, by Ludwig Berger (1777-1839). In addition, Frede ric Kalkbrenne r (1785-1849) composed numerous etudes, such as 24 Etudes, Op. 20; Méthode pour Apprendre le Piano-Forte à l'aide du Guide-mains, Op. 108; 25 grandes études de style et de perfectionnement, Op. 143; 12 études progressives, Op. 161; and Etudes pour le Piano, Op. 185. Ignaz Moscheles (1794-1870) wrote many etudes mostly in advanced level, such as 24 Etudes, Op. 70; Characteristic Studies, Op. 95; Deux Etude, Op. 105; and Grande Etude de Concert, Op. 126.

All these etude collections are used as piano method books emphasizing technical demands for the hands, rather than musical and aesthetic value. However, to avoid the monotony of mechanical exercises, these composers consciously used melody, harmony and form to enrich the music, which promoted the gradual transformation of later etudes into expressive character pieces. 


\subsection{Etudes in Romantic Era}

Under the influence of Romanticism in music, the etude has undergone major transformation since 1830, with more attention paid to great artistic depth and musical content. While continuing to display virtuosity, these kinds of etudes include significant artistic content, they are well-suited for recital performance, and are often referred to as "concert etudes."

Robert Schumann (1810-1856), a German composer and influential critic, composed a number of etudes. Influenced by Paganini's 24 Caprices for Violin, he wrote Etudes after Caprices of Paganini, Op. 3 (1833), and Six Concert Etudes after Paganini Caprices, Op. 10 (1835). More than simply transcribed, they are elaborated by using counterpoint and imitation. ${ }^{81}$ Symphonic Etudes, Op. 13 (1852) is well-known and technically demanding. Combining the concepts of etudes and variations, Op. 13 includes a theme and 12 etudes in a variety of moods and tempos. ${ }^{82}$ Each etude relates to the theme and focuses on varying technical problems. The theme acts as an overarching unifying factor and this work is to be played in its entirety without any break, lasting half an hour.

Frédéric Chopin (1810-1849), a Polish composer and virtuoso pianist, wrote 27 etudes:12 each in Op. 10 (1833) and Op. 25 (1838), and three without opus number known as Trois nouvelles études ("three new studies," 1839). ${ }^{83}$ From a pianistic point of view, his etudes are technically difficult and most of them are focused on a single problem. For instance, arpeggio (Op. 10, No. 1, 8), double thirds or sixths (Op. 25, No. 6, 8), octaves (Op. 25, No. 10), black keys (Op. 10, No. 5), and left-hand skips (Op. 25, No. 4). Most of Chopin's etudes are written in ternary form and many of them include an extensive coda. ${ }^{84}$ From the perspective of artistic

\footnotetext{
${ }^{81}$ Gordon, “A His tory of Keyboard Literature," 275.

${ }^{82}$ Gordon, "A His tory of Keyboard Literature," 275.

${ }^{83}$ Gordon, "A His tory of Keyboard Literature," 284.

${ }^{84}$ Gordon, "A His tory of Keyboard Literature," 284.
} 
value, his etudes are incredibly emotional and musical. Some open with a bright, uplifting theme, such as Op. 10 No. 1, 4, 8. Not all the etudes are concerned with fast fingers, and some etudes open with a lyrical theme. For example, Op. 10, No. 3, 6 and Op. 25, No. 7 are written as studies in expressive playing. Skillful modulations and fresh harmonic concepts also create a wonderful sense of dramatic effect in his etudes. Many of the etudes bear nicknames; however, these titles were assigned by music publishers, not by Chopin himself. Though there are always some arguments about the nicknames, they are still widely used nowadays; for instance, Op. 10, No. 12 , in c minor is called the "Revolutionary" etude, because a historic event - the fall of Warsaw in 1831-inspired Chopin's composition, which is also a study for the development of left-hand technique. ${ }^{85}$

Franz Liszt (1811-1886), Hungarian composer and virtuoso pianist, wrote a series of etudes through his youth to later life, including 12 Etudes d'execution transcendante, S. 139 (final version 1852); Six Grandes études de Paganini, S. 141 (final version 1851); Trois etudes de concert, S. 144 (1849); Zwei Konzertetüden, S. 145 (1862-3); and Technische Studien, S. 146 (1868-1872). Compared to Chopin's etudes, Liszt's etudes feature descriptive titles and are mostly designed to develop a set of techniques, including a pervasive presence of octaves, double notes, rolled chords, skips, passages of rapid scales or arpeggios, and cadenzas throughout the etude ${ }^{86}$ Liszt's etudes are often somewhat longer than those by other composers. He enriched his etudes by including more powerful sounds, more complex structures, and wider dynamic range, density and intensity, often achieving rich orchestra-like textures.

Another well-known Romantic composer, Johannes Brahms (1833-1897), wrote Five Studies, Op. 25 and 51 Exercises for Piano. His contribution to the etude genre is much smaller

\footnotetext{
${ }^{85}$ Gordon, "A History of Keyboard Literature," 285.
}

${ }^{86}$ Gordon, "A History of Keyboard Literature," 310. 
than that of Chopin, Liszt, or Schumann. The five Brahms etudes are transcriptions of other composers' works, including Chopin Etude (Op. 25, No. 2), Schubert Impromptu (Op. 90, No. 2), Weber Rondo and Bach Violin Sonata. ${ }^{87}$ Encompassing a wide variety of technical problems, 51 Exercises for Piano is a collection of original finger exercises in various lengths, with the shortest one having only two lines.

In the first half of the $19^{\text {th }}$ century, the etude developed from didactic material for everyone to concert pieces suitable for advanced students or artists. In the second half of the century, more composers contributed to etude repertoire. While some wrote etudes with pedagogic content, some were inspired by Chopin and Liszt, and they followed that path by assimilating etudes with expressive character pieces. A partial list of additional composers who contributed etudes in the Romantic era follows below:

${ }^{87}$ Gordon, “A His tory of Keyboard Literature,” 344. 


\begin{tabular}{|c|c|}
\hline Henri Herz (1803-1888) & $\begin{array}{l}30 \text { etudes progressives, Op. 119; } 24 \text { etudes tres faciles, Op. 151; } \\
24 \text { études faciles, Op. 152; } 18 \text { Grandes etudes de concert, Op. } \\
\text { 153; } \\
\text { Études de l'agilité, Op. } 179\end{array}$ \\
\hline Frederic Burgmüller (1806-1874) & 25 Études faciles et progressives, Op. 100; 18 Études, Op. 109 \\
\hline Felix Mendelssohn (1809-1847) & Three Etudes, Op. 104 \\
\hline Sigismond Thalberg (1812-1871) & 12 Etüden für Pianoforte, Op. 26 \\
\hline Stephen Heller (1813-1888) & $\begin{array}{l}\text { L'art de phraser, Op. 16; La chasse, Op. 29; } 25 \text { Etudes } \\
\text { mélodiques, Op. 45; } 30 \text { Études mélodiques et progressives, Op. } \\
\text { 46; } 25 \text { studies, Op. 47; } 24 \text { Nouvelles Études, Op. 90; Grande } \\
\text { étude, Op. 96; } 2 \text { études, Op. 116; } 24 \text { Etudes d'Expression et de } \\
\text { Rhythme, Op. 125; } 3 \text { Etudes, Op. 139; } 2 \text { Etudes, Op. 151; } 21 \\
\text { Etudes Speciales after Chopin, Op. } 154\end{array}$ \\
\hline Charles-Valentin Alkan (1813-1888) & $\begin{array}{l}12 \text { études dans tous les tons majeurs, Op. 35; } 12 \text { études dans tous } \\
\text { les tons mineurs, Op. 39; Trois grandes études, Op. } 76\end{array}$ \\
\hline Adolf Henselt (1814-1889) & 12 Études caractéristiques, Op. 2; Douze Études de salon, Op. 5 \\
\hline Anton Rubinstein (1829-1894) & Six Etudes, Op. 23 \\
\hline Camille Saint-Saëns (1835-1921) & $\begin{array}{l}6 \text { Études, Op. 52; } 6 \text { Études, Op. 111; } 6 \text { Études pour la main } \\
\text { gauche seule, Op. } 135\end{array}$ \\
\hline Moritz Moszkowski (1854-1925) & $\begin{array}{l}15 \text { Etudes de Virtuosité, Op. 72; Three Etudes, Op. 78; } 20 \text { Petites } \\
\text { Etudes, Op. 91; } 12 \text { Etudes for the Left Hand, Op. 92; Esquisses } \\
\text { Techniques, Op. } 97\end{array}$ \\
\hline Sergei Lyapunov (1859-1924) & 12 Transcendental Etudes, Op. 11 \\
\hline Anton Arensky (1861-1906) & $\begin{array}{l}\text { Six Essais sur des rythmes oubliés, Op. 28; Four Etudes, Op. } 41 ; \\
12 \text { Etudes, Op. } 74\end{array}$ \\
\hline $\begin{array}{l}\text { Edward Alexander MacDowell (1860- } \\
\text { 1908) }\end{array}$ & $\begin{array}{l}\text { Etude de Concert, Op. 36; Twelve Studies, Op. 39; Twelve } \\
\text { Virtuoso Studies, Op. } 46\end{array}$ \\
\hline
\end{tabular}

Chart 1: Etudes in the Romantic era 8889

88 “IMSLP Petrucci Music Library,” accessed Apr. 05, 2019, https://ims lp.org/wiki/Main_Page/.

${ }^{89}$ Gordon, “A History of Keyboard Literature," 244. 


\subsection{Etudes in Twentieth Century}

In the twentieth century, composers kept expanding their musical vocabulary with new methods and concepts. There were two main compositional paths. One was further development of elements of tonality, such as scales, chords, and textures. The other was to abandon the traditional harmonic system by experimenting with atonal and serial music. Music from the twentieth century is more diverse than that composed in previous eras, reflecting a large variety of styles, ranging from impressionism and expressionism to neoclassicism, minimalism, and neoRomanticism, along with experimental music, electronic music, indeterminacy, chance and other new approaches. ${ }^{90}$ These trends were also reflected in etude writing. In the early $20^{\text {th }}$ century, many etudes were written by a growing number of composers in Russia, America, and elsewhere.

Claude Debussy (1862-1918), one of the best-known "Impressionist" composers, wrote Douze Etudes (1915), a set of 12 pieces inspired by previous composers he admired, including Carl Czerny and Chopin. ${ }^{91}$ Each etude focused on a concrete musical idea and the technical issues include double thirds, fourths, sixths, octaves, chromatic intervals, ornaments, repeated notes, opposing sonorities, composite arpeggios, and chords. As technically difficult pieces suitable for advanced students or artists, the 12 etudes feature multiple tempo and meter changes, a variety of key signatures, wide dynamic range, shifting tonal centers and coloristic harmonies derived from various modes or scales.

Alexander Nikolaye vich Scriabin (1872-1915), wrote 26 etudes through his youth to later life. His output includes Étude in C-sharp minor, Op. 2, No. 1 (1887); 12 Études, Op. 8 (1894); Eight Études, Op. 42 (1903); Étude in E-flat major, Op. 49, No. 1 (1905); Étude, Op. 56, No. 4

\footnotetext{
${ }^{90}$ Burkholder, Grout, and Palisca. “A History of Western Music," 757.

${ }^{91}$ Gordon, “A History of Keyboard Literature," 379.
} 
(1908); and Three Études, Op. 65 (1912). The etudes composed before 1900 were modeled on the works of Chopin, in late-romantic style. After 1900, his style began to change. ${ }^{92}$ Eight Études, Op. 42, written in 1903, were considered as transitional works, rooted in tonality but featuring extreme chromatic and metrical complexity. The etudes written after 1903, for example the Op. 65 set, really represented his late style, with increasing atonal elements, omitted key signature, unusual harmonies like his mystic chord ${ }^{93}$ bichord ${ }^{94}$ and constant dissonances including ninths and major sevenths.

Olivier Messiaen (1908-1992), an important composer who contributed to the development of total serialism, wrote Quatre Études de rythme (Four Rhythm Studies) between 1949 and 1950. The four etudes with titles represented his rhythmical concerns and the second etude, "Mode of Durations and Intensities," was written within the concept of total serialism, organizing the music around a melodic mode of 36 pitches, 24 durations, 12 attacks, and 7 dynamics. ${ }^{95}$

Additional composers who contributed to etudes before 1950 are listed below:

\footnotetext{
${ }^{92}$ Gordon, “A His tory of Keyboard Literature,” 430.

${ }^{93}$ Mystic chord: a collection of sixtones used in the later music of Alexander Scriabin (for example, C-F\#-Bb-E-AD).

${ }^{94}$ Bichord: any combination of two chords. Scriabin derived his own bichords fromfourth-based chords.

${ }^{95}$ Gordon, "A History of Keyboard Literature," 402.
} 


\begin{tabular}{|c|c|}
\hline $\begin{array}{l}\text { Sergey Vassilievich Rachmaninoff } \\
(1873-1943)\end{array}$ & Etudes-tableaux, Op. 33; Etudes-tableaux, Op. 39 \\
\hline Ernst von Dohnanyi (1877-1960) & Six Concert Etudes, Op. 28 \\
\hline $\begin{array}{l}\text { Nikolay Karlovich Medtner (1880- } \\
\text { 1951) }\end{array}$ & $\begin{array}{l}\text { Etude in G-sharp minor, Op. } 4 \text { No. } 1 ; \text { Etude in } C \\
\text { minor }\end{array}$ \\
\hline Bela Bartỏk (1881-1945) & Three Etudes, Op. 18 \\
\hline $\begin{array}{l}\text { Igor Fyodorovich Stravinsky (1882- } \\
\text { 1971) }\end{array}$ & Quatre études, Op. 7 \\
\hline Karol Szymanowski (1882-1937) & Four Études, Op. 4; 12 Études, Op. 33 \\
\hline Sergey Prokofiev (1891-1953) & Four Etudes, Op. 2; Etude, Op. 52 No. 3 \\
\hline Erwin Schulhoff (1894-1942) & Cinq études de jazz. \\
\hline Virgil Thomson (1896-1989) & Ten Etudes for Piano; Nine Etudes ${ }^{96}$ \\
\hline Hermann Heiss (1897-1966) & Twelve-Tone Etude for Piano \\
\hline Alexander Tcherepnin (1899-1977) & $\begin{array}{l}\text { Etude du piano sur la gamme pentatonique (Piano } \\
\text { Study on the Pentatonic Scale), Op. 51; Five } \\
\text { (Chinese) Concert Etudes, Op. 52; Technical } \\
\text { Exercises on the Five Note Scale, Piano Studies, Op. } \\
\text { 53; Seven Etudes for Piano, Op. } 56\end{array}$ \\
\hline
\end{tabular}

Chart 2: Etudes before 19509798

The etudes written after 1950 continue the diversity in compositional styles and focus more on sound, tone color, and complex rhythms. The three books of Études pour piano by György Ligeti (1923-2006) have gained popularity and a place in the contemporary etude repertory. Book 1 (1985), Book 2 (1988-1994) and Book 3 (1995-2001) have six, eight and four etudes, respectively. Influenced and inspired by the models of previous generations of composers, such as Chopin, Liszt and Debussy, Ligeti also explored new avenues by opening up new approaches

\footnotetext{
96 "Works of Virgil Thomson,” accessed Apr. 05, 2019, http://works.virgilthomson.org/.

97 “IMSLP Petrucci Music Library,” accessed Apr. 05, 2019, https://imslp.org/wiki/Main_Page/.

${ }^{98}$ Gordon, “A History of Keyboard Literature," 435, 454, 438.
} 
to traditional technical problems, such as various forms of polyrhythm and polymeter. ${ }^{99}$ Other compositional techniques include use of harmonies derived from various modes or scales, such as pentatonic and heptatonic scales. Each etude has a title. Some titles indicate basic musical techniques and some create an image or story for the learners.

Other types of etudes in the second half of the $20^{\text {th }}$ century include transcriptions of other composers' works. Among these are the Seven Virtuoso Études After Gershwin (1989) by Earl Wild (1915-2010), based on Gershwin songs; the Four Etudes on Brahms Songs, Op. 88 (2004) and the Four Etudes on Songs of Robert Franz, Op. 91 (2005), by Lowell Liebermann (1961- ); and the 12 Études in All the Minor Keys (1984) by Marc-André Hamelin (1961- ).

Other recent etude styles include:

- Minimalist music-Philip Glass (1937- ) Etude for Piano (1994);

- Extended technique and unusual notation/extended notational systems - John Cage (19121992) Etudes Australes (1974-75) and Etude Boreales (1978); William Bolcom (1938- ) Twelve Etudes (1971) and Twelve New Etudes (1988);

- The fusion of classical virtuosity and jazz-Nikolai Kapustin (1937- ) The Eight Concert Etudes, Op. 40 (1984), Three Etudes, Op. 67 (1991) and Five Etudes in Different Intervals, Op. 68 (1992).

Several other composers who contributed etudes after 1950 are listed below:

\footnotetext{
${ }^{99}$ Eun Young Kang, "Late Twentieth-Century Piano ConcertEtudes: A Style Study” (DMA diss., University of Cincinnati, 2010), 81-82.
} 


\begin{tabular}{|l|l|}
\hline Maurice Ohana (1913-1992) & $\begin{array}{l}\text { Douze Etudes d'interprétation I (No. 1-6 for } \\
\text { piano solo) and II (No. 7-10 for piano solo and } \\
\text { No. 11-12 for piano and percussion) }\end{array}$ \\
\hline George Perle (1915-2009) & Six Etudes; Six New Etudes \\
\hline Noël Lee (1924-2013) & Four Etudes for piano, Set 1\& 2 \\
\hline Einojuhani Rautavaara (1928-2016) & Six Etydit (Études), Op. 42 \\
\hline H. Leslie Adams (1932- ) & Twenty-Six Etudes for Solo Piano \\
\hline John Corigliano (1938- ) & Etude Fantasy \\
\hline PascalDusapin (1955-) & Sept études pour piano \\
\hline David Rakowski (1958-) & 100 piano Études \\
\hline Unsuk Chin (1961- ) & 12 Piano Etudes \\
\hline
\end{tabular}

Chart 3: Etudes after 1950100101102103104105106107108

${ }^{100}$ Caroline Rae, "The Piano Music of Maurice Ohana," Revista Música 6, no. 1-2(1995): 44-74.

101 "George Perle," acces sed A pr. 05, 2019, https://georgeperle.net/catalog/solo-and-chamber-music/.

102 "NoëlLee," accessed A pr. 05, 2019, http://www.noel-lee.com/english/compositions.htm/.

103 "Etydit-Etudes by Einojuhani Rautavaara," accessed Apr. 05, 2019, https://core.musicfinland.fi/works/etyditetudes-d98feb32-75e5-4630-be63-927903c4283c/.

104 “Composer John Corigliano," accessed Apr. 05, 2019, http://www.johncorigliano.com/index.php?p=item2\&item=61/.

105 I-Chen Yeh, "The Piano Etudes of David Rakowski" (DMA dis s., Bowling Green State University, 2010), 20146.

${ }^{106}$ Soo Kyung Kim, “A Study of Unsuk Chin's Piano Etudes”(DMA diss., the University of Georgia, 2012), 13. 107 “IMSLP Petrucci Music Library," accessed Apr. 05, 2019, https://imslp.org/wiki/Main_Page/.

${ }^{108}$ Aaron Balthazar Mathews, "H. Les lie Adams' Twenty-SixEtudes for Solo Piano: A Performance and Sty lis tic Analysis"(DMA diss., University of South Carolina, 2015), 23. 


\section{Chapter V. Analysis of the Eight Concert Etudes}

\subsection{Overview of the Eight Concert Etudes}

Kapustin's Eight Concert Etudes, Op. 40, were written in 1984, the same year as Piano Sonata No. 1, Op. 39 ("Sonata-Fantasy"), and Variations, Op. 41. These etudes appear fairly frequently in concert programs now and each etude has a descriptive title. From the first etude (Prelude) to the last (Finale), each title conveys for its etude the impression of being a character piece. Kapustin explores new avenues after the famous etudes by Chopin, Liszt, and Rachmaninoff, combining traditional technical writing with fresh approaches to jazz music. $\mathrm{He}$ focuses on more than one single problem in each etude; in that sense, these pieces follow more directly from Liszt and Rachmaninoff than from Chopin.

The chart below summarizes general information for each etude. Note that the last etude is the only one without a metronome marking in the original score. 


\begin{tabular}{|c|c|c|c|c|c|c|}
\hline & $\begin{array}{l}\text { Tempo } \\
\text { Marking }\end{array}$ & Key & $\begin{array}{l}\text { Length } \\
\text { (bars) }\end{array}$ & Technical Devices & $\begin{array}{l}\text { Timing } \\
\text { (approx } \\
\text { i-mate)* }\end{array}$ & $\begin{array}{l}\text { Metro- } \\
\text { nome } \\
\text { Marking }\end{array}$ \\
\hline $\begin{array}{l}\text { Etude No. } 1 \\
\text { (Prelude) }\end{array}$ & $\begin{array}{l}\text { Allegro } \\
\text { assai }\end{array}$ & $\begin{array}{l}\mathrm{C} \\
\text { major }\end{array}$ & 70 & $\begin{array}{l}\text { LH wide leaps, octaves, } \\
\text { rhythmic complexities, } \\
\text { voicing/balance }\end{array}$ & 2: 10 & $=144$ \\
\hline $\begin{array}{l}\text { Etude No. } 2 \\
\text { (Reverie) }\end{array}$ & Moderato & $\begin{array}{l}\mathrm{Ab} \\
\text { major }\end{array}$ & 138 & $\begin{array}{l}\text { RH double notes, LH } \\
\text { wide leaps, arpeggiated } \\
\text { chords, broken octaves, } \\
\text { melodic } 3^{\text {rd }}, 2^{\text {nd }}\end{array}$ & $4: 20$ & . $=92$ \\
\hline $\begin{array}{l}\text { Etude No. } 3 \\
\text { (Toccatina) }\end{array}$ & Allegro & $\begin{array}{l}\mathrm{e} \\
\text { minor }\end{array}$ & 69 & $\begin{array}{l}\text { repeated notes, octaves, } \\
\text { hand crossing, } \\
\text { rhythmic complexities, } \\
\text { voicing/balance }\end{array}$ & $2: 30$ & $=132$ \\
\hline $\begin{array}{l}\text { Etude No. } 4 \\
\text { (Reminiscence) }\end{array}$ & Larghetto & $\begin{array}{l}\mathrm{B} \\
\text { major }\end{array}$ & 71 & $\begin{array}{l}\text { scalar patterns, } \\
\text { arpeggios, octaves, } \\
\text { chords }\end{array}$ & $5: 30$ & $d=60$ \\
\hline $\begin{array}{l}\text { Etude No. } 5 \\
\text { Shuitka } \\
\text { (Raillery) }\end{array}$ & Vivace & $\begin{array}{l}\mathrm{D} \\
\text { major }\end{array}$ & 108 & $\begin{array}{l}\text { rhythmic complexities, } \\
\text { broken octaves, skips, } \\
\text { arpeggiated figure }\end{array}$ & $2: 35$ & $d=192$ \\
\hline $\begin{array}{l}\text { Etude No. } 6 \\
\text { (Pastoral) }\end{array}$ & $\begin{array}{l}\text { Allegro } \\
\text { moderato }\end{array}$ & $\begin{array}{l}\mathrm{Bb} \\
\text { major }\end{array}$ & 70 & $\begin{array}{l}\text { skips, arpeggios, } \\
\text { intervals of fourths, } \\
\text { fifths and sixths, } \\
\text { chords, voicing/balance }\end{array}$ & $3: 05$ & $=108$ \\
\hline $\begin{array}{l}\text { Etude No. } 7 \\
\text { (Intermezzo) }\end{array}$ & Allegretto & $\begin{array}{l}\mathrm{Db} \\
\text { major }\end{array}$ & 101 & $\begin{array}{l}\text { double thirds, skips, } \\
\text { chords, rhythmic } \\
\text { complexities }\end{array}$ & $4: 25$ & $=126$ \\
\hline $\begin{array}{l}\text { Etude No. } 8 \\
\text { (Finale) }\end{array}$ & Prestissimo & $\begin{array}{l}f \\
\text { minor }\end{array}$ & 192 & $\begin{array}{l}\text { chromatic figuration, } \\
\text { arpeggios, skips, } \\
\text { octaves }\end{array}$ & 3: 00 & \\
\hline
\end{tabular}

\footnotetext{
* Timing for the etudes are taken from Catherine Gordeladze's record "Kapustin: 8 Concert Etudes - 24 Preludes."
}

Chart 4: General information for each etude 


\subsubsection{Musical Form in the Etudes}

From a structural point of view, these eight etudes are composed in various formal designs and can be divided into two categories-classical forms and common jazz song forms. ${ }^{109} 110$ Five of the etudes display classical formal structure. These are Etude No. 1 (Prelude), No. 2 (Reverie), No. 4 (Reminiscence), No. 5 (Raillery), and No. 7 (Intermezzo). Etude No. 2 (Reverie), as a typical example, will be analyzed in detail in the next subsection.

Etude No. 1 (Prelude) is written in quasi rondo form, based on two contrasting themes (Example 1). The section that combines the material from B and A appears twice in a similar manner (Example 2), followed by new quasi-improvisational material labeled here as section $\mathrm{C}$ (Example 3). Thus, Etude 1 is divided into five sections, with structure outlined as $A B\left(B^{\prime}+A^{\prime}\right) C$ $\left(\mathrm{B}^{\prime}+\mathrm{A}^{\prime}\right)$, plus a four-bar driving and climactic coda.
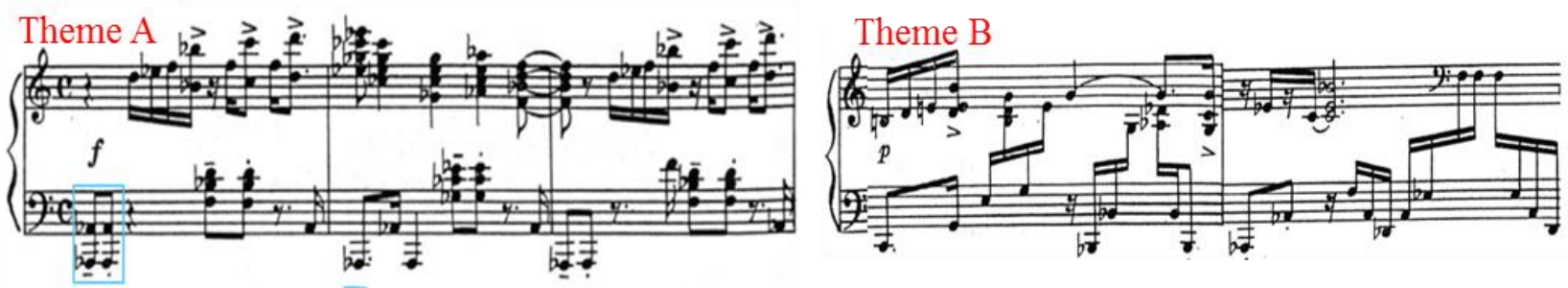

Example 1: Etude No. 1, theme A, mm. 1-3 and theme B, mm. 13-14

\footnotetext{
${ }^{109}$ Most Jazz tunes and standards are made up of eight-bar phrases, and each of these phrases can be assigned a letter, such as "A," "B," "C," or "D." The most common formplayed in jazz is "AABA," with 32 bars total length. Other common forms include ABAC, AABC, ABCD, ABA, ABC, AAB and AB. Each form is usually repeated, for example AABCAABC.

${ }^{110}$ Mark Levine, The Jazz Theory Book. (Petaluma, CA: Sher Music Co., 1995), 383.
} 


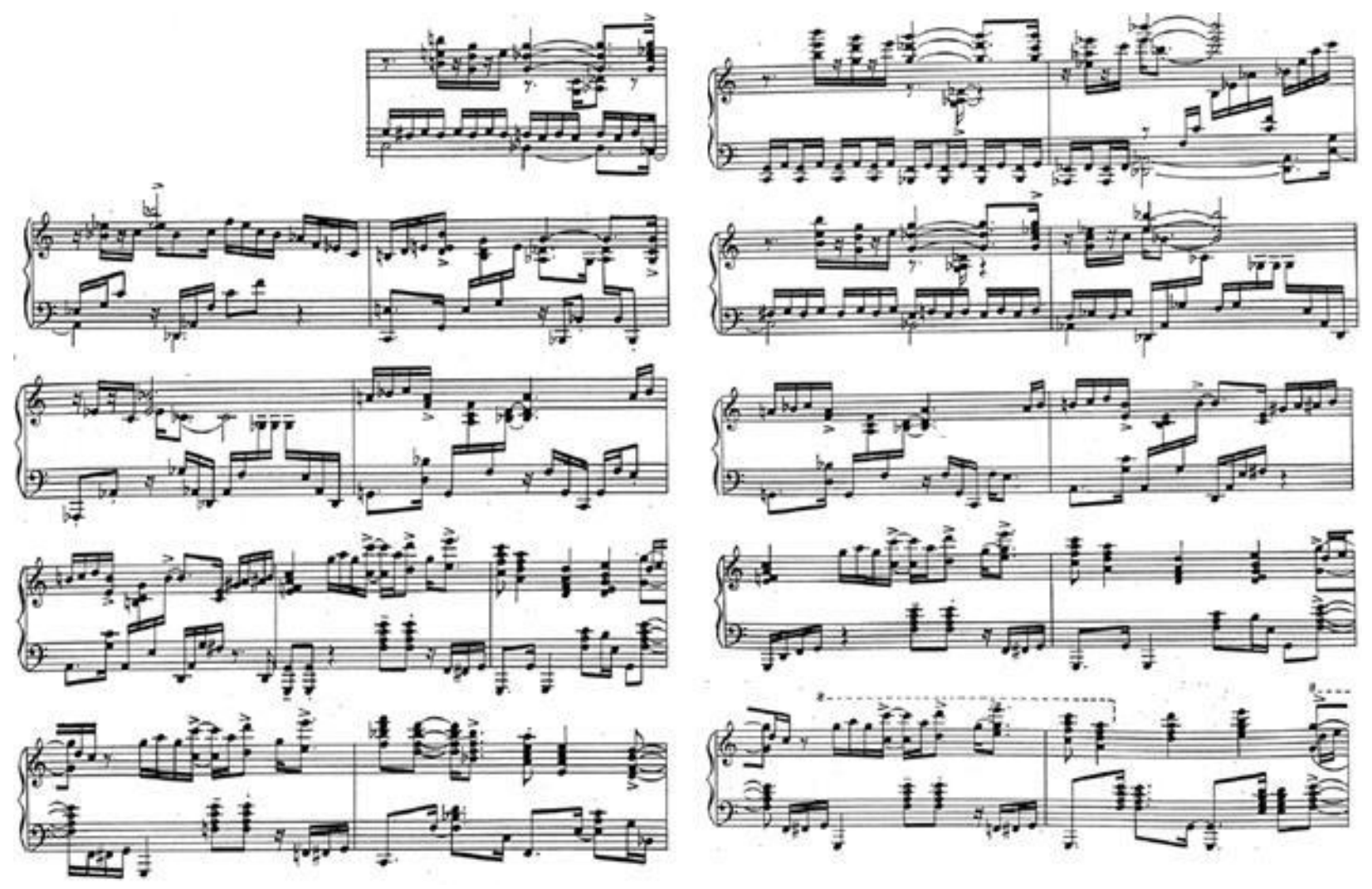

Example 2: Etude No. 1, $1^{\text {st }}$ section B'+A', mm. 29-40 and $2^{\text {nd }}$ section B' $+A^{\prime}$, mm. 57-66

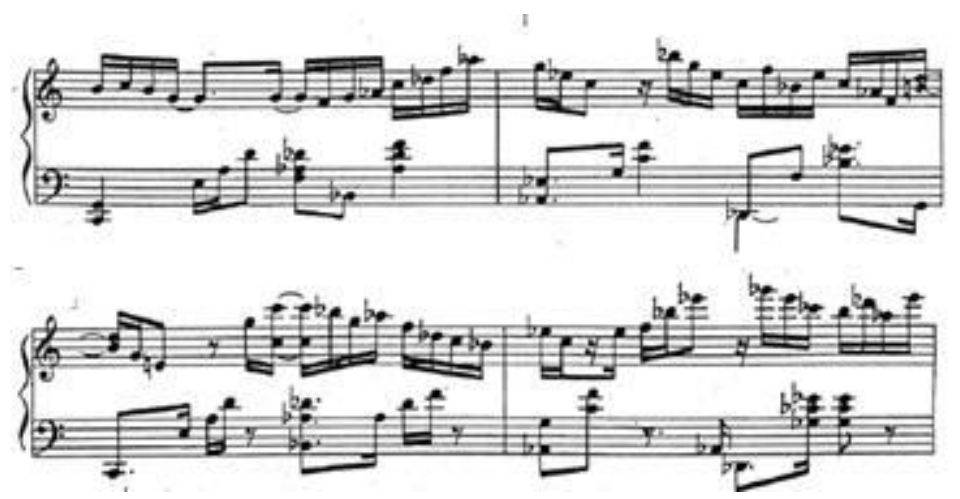

Example 3: Etude No. 1, part of section C, mm. 41-44

Etude No. 4 (Reminiscence) employs ternary form (ABA). The A section features 32nd-note running passages in the right hand, with chordal accompaniment in the left hand. The role of each hand reverses in the B section, with the left hand playing runs and the right hand presenting 
chords. As might be expected, the texture switches back to the original configuration at the return of the A section.

Another example in ternary form (ABA) is Etude No. 5 (Raillery). The A section is written in boogie-woogie style, in which the right hand plays a series of improvisatory passages against a driving ostinato bass in a repetitive 12-bar blues progression, conveying a cyclic feeling. The length of refrain is varied, not strictly within the 12-bar structure. The contrasting B section, more vibrant and energetic in character, employs different rhythmic patterns and textures. The return of the A section brings us back to stability and a recognizable boogie-woogie bass pattern. The etude ends with a four-bar coda that is derived from the opening material of the B section.

Etude No. 7 (Intermezzo) is composed in ternary form. In this etude, each of the first two sections has two sub-sections which are repeated. It opens with a four-bar introduction and connects with a four-bar interlude. However, the third section, with a four-bar coda, is in free form, not in two repeated sections. In addition to the third variation of A and B, there is an eightbar phrase that mixes the material of $\mathrm{A}$ and $\mathrm{B}$ by using a rhythmic pattern from $\mathrm{A}$, with an ascending-second interval motif and two-bar groups from B (Example 4). ${ }^{111}$ The structure can be diagrammed as [(Intro) $\left(1 \mathrm{~A}-1 \mathrm{~A}^{\prime}-1 \mathrm{~B}-1 \mathrm{~B}^{\prime}\right)($ Interlude $)\left(2 \mathrm{~A}-2 \mathrm{~A}^{\prime}-2 \mathrm{~B}-2 \mathrm{~B}^{\prime}\right)(3 \mathrm{~A}-3 \mathrm{~B}-\mathrm{A} / \mathrm{B})($ coda $\left.)\right]$. The etude uses thematic transformation to develop two fundamental musical ideas, ${ }^{112} \mathrm{~A}$ and $\mathrm{B}$; each repetition in A or B is varied, either in altered form or accompanied in a different manner. For instance, the A theme reappears in several variations (see Example 5): changing the rhythm of the melody (while keeping the pitch the same) and accompaniment (see Example 6); thickening of the texture and changing the pitch of notes over the same harmonic progression (see Example 7); different types of figuration in the right hand over the same harmonic

\footnotetext{
${ }^{111}$ Okamoto, "Reflections on Analysis," 83.

${ }^{112}$ Jiwon Choi, "An Eclectic Combination of Clas sical and Jazz Idioms: Nikolai Kapustin's Piano Works" (PhD diss., University of Kansas, 2015), 14.
} 
progression (see Example 8); and using diminution in harmonic progression and changing the accompaniment by using stride bass and walking tenth (see Example 9).
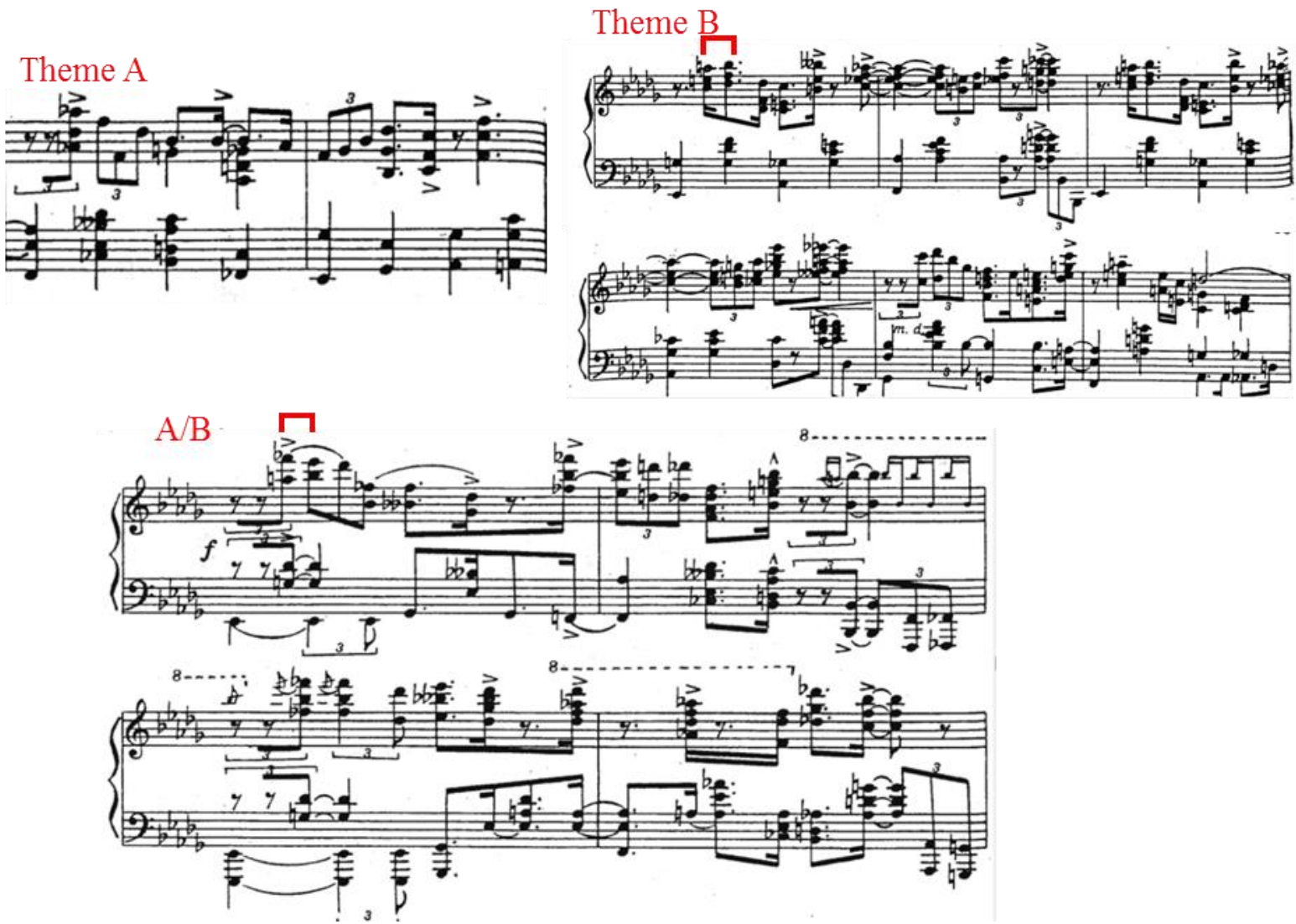

Example 4: Etude No. 7, part of mixing A\&B, mm. 90-94

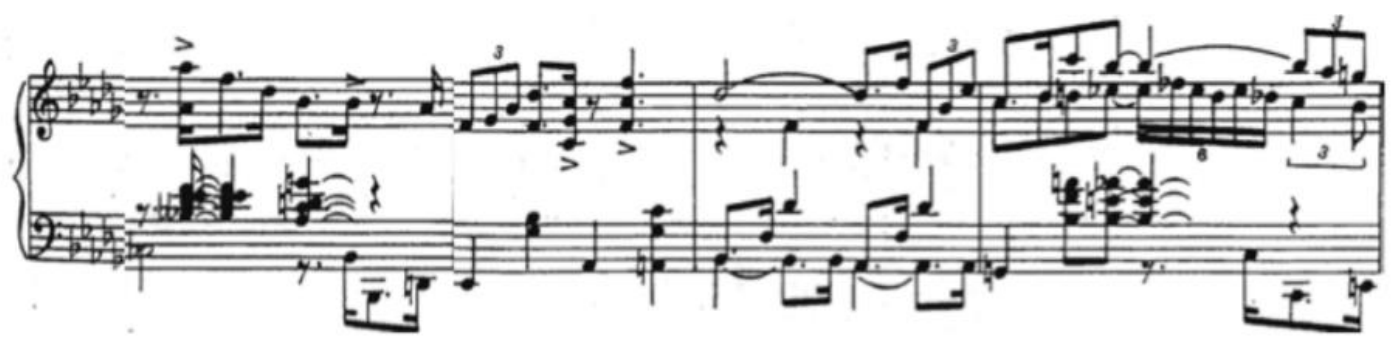

Example 5: Etude No. 7, part of 1A, mm. 5-8 


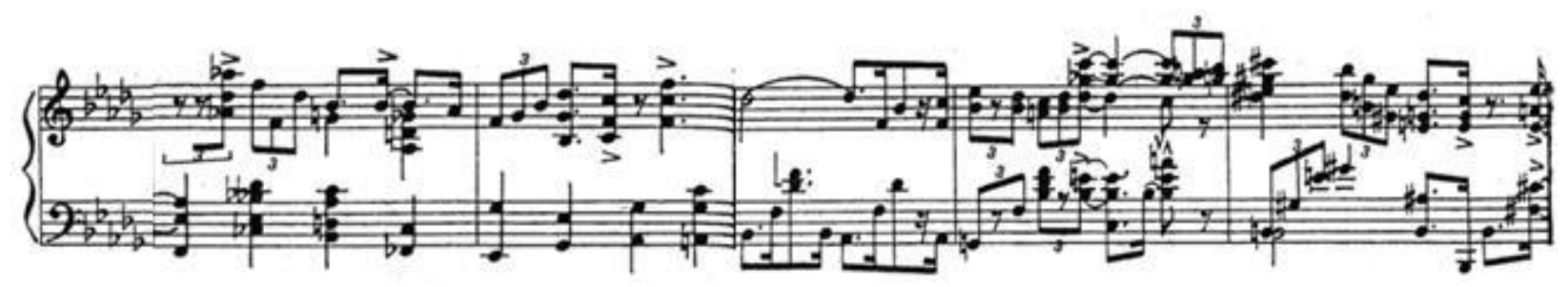

Example 6: Etude No. 7, part of 1A', mm. 13-17
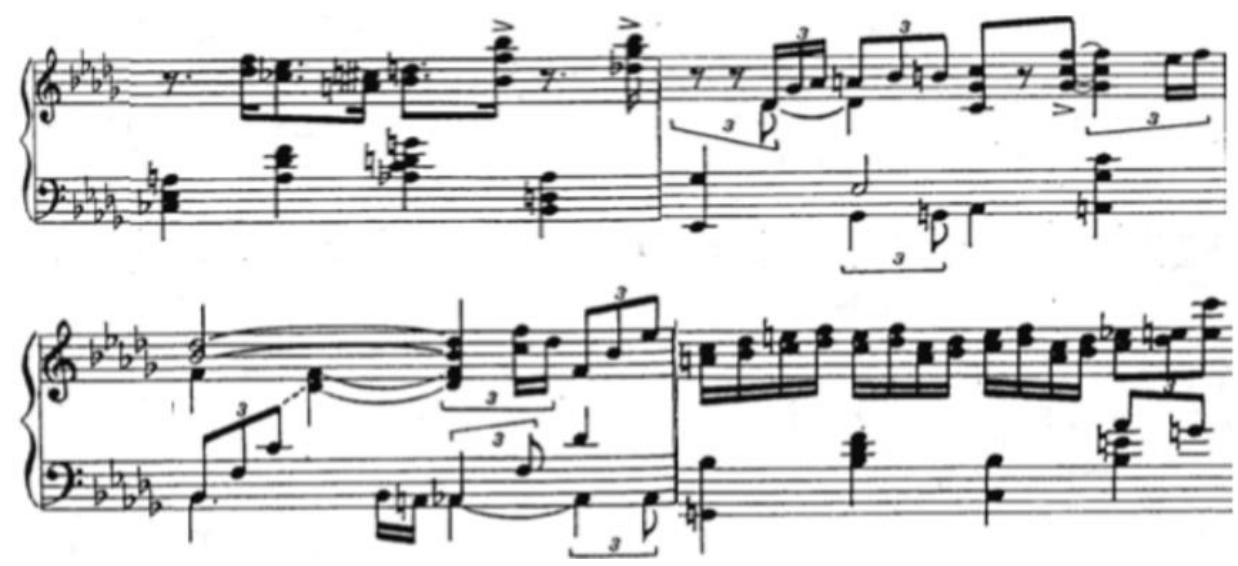

Example 7: Etude No. 7, part of 2A, mm. 43-46
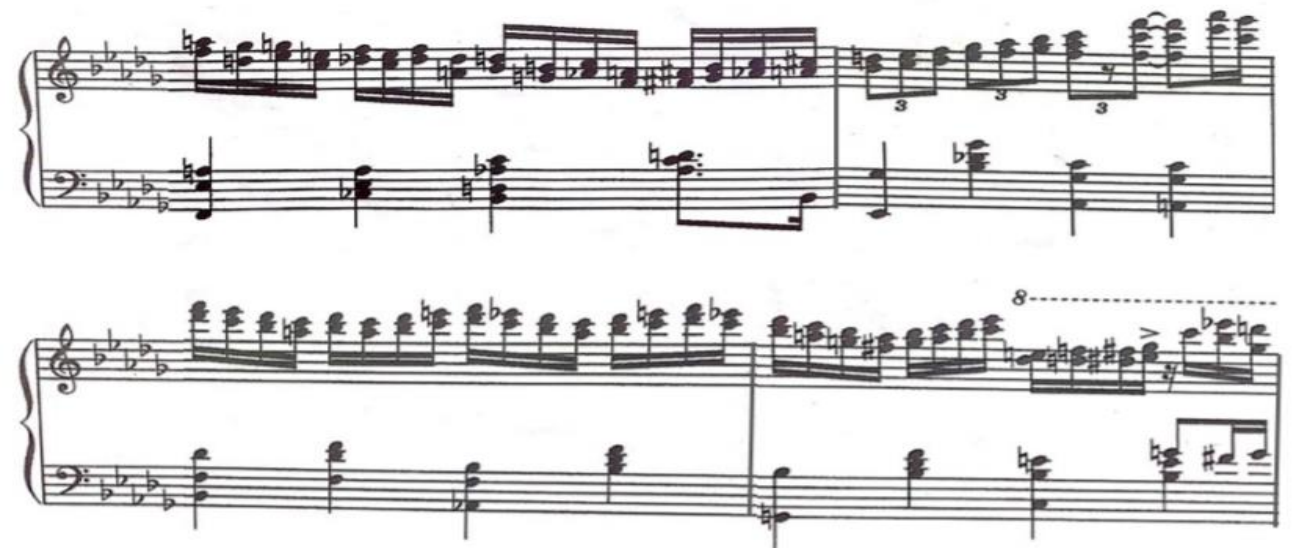

Example 8: Etude No. 7, part of 2A', mm. 51-54 


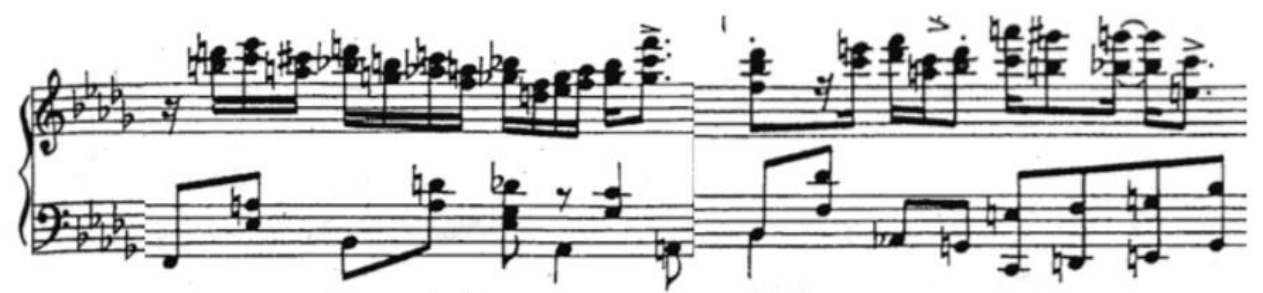

Example 9: Etude No. 7, part of 3A, mm. 75-76

The etudes which reveal the influence of common jazz song forms are Etude No. 3 (Toccatina), Etude No. 6 (Pastoral), and Etude No. 8 (Finale). Among these, Etude No. 8 (Finale) is arranged in $\mathrm{AABC}$ form with increased complexity in each section; this piece will be analyzed in detail in the next subsection.

Etude No. 3 (Toccatina) is written in AAB jazz song form, with the entire structure repeated. The overall structure is $\mathrm{AABAAB}$ with a seven-bar introduction and a seven-bar coda. Normally, each section is eight bars long. However, in this etude, we see a four-bar tag added to the first B section and a three-bar tag added to the last B section, making the first AAB section 28 bars long (8-8-12) and the second AAB section 27 bars long (8-8-11).

Etude No. 6 (Pastoral) is composed in 32-bar popular song (AABC) form with eight bars in each section; the entire structure is repeated. The overall structure is AABCAABC, ending with an eight-bar coda based on the material of A. However, the tag is shortened by two bars in the second $\mathrm{C}$ section, making the second $\mathrm{AABC}$ section 30 bars long (8-8-8-6).

\subsubsection{Techniques in the Etudes}

\section{Classical Techniques}

From the technique point of view, these eight etudes are written as a complementary combination of jazz techniques and the typical $19^{\text {th }}$-century virtuosic etude writing. In the 
classical aspect, the traditional technical problems addressed in the composition include alternating double notes for the right hand in Etude No. 2 (Reverie) (Example 10), repeated notes in Etude No. 3 (Toccatina) (Example 11), rapid arpeggio figuration in Etude No. 4 (Reminiscence) (Example 12), and double thirds in Etude No. 7 (Intermezzo) (Example 13).
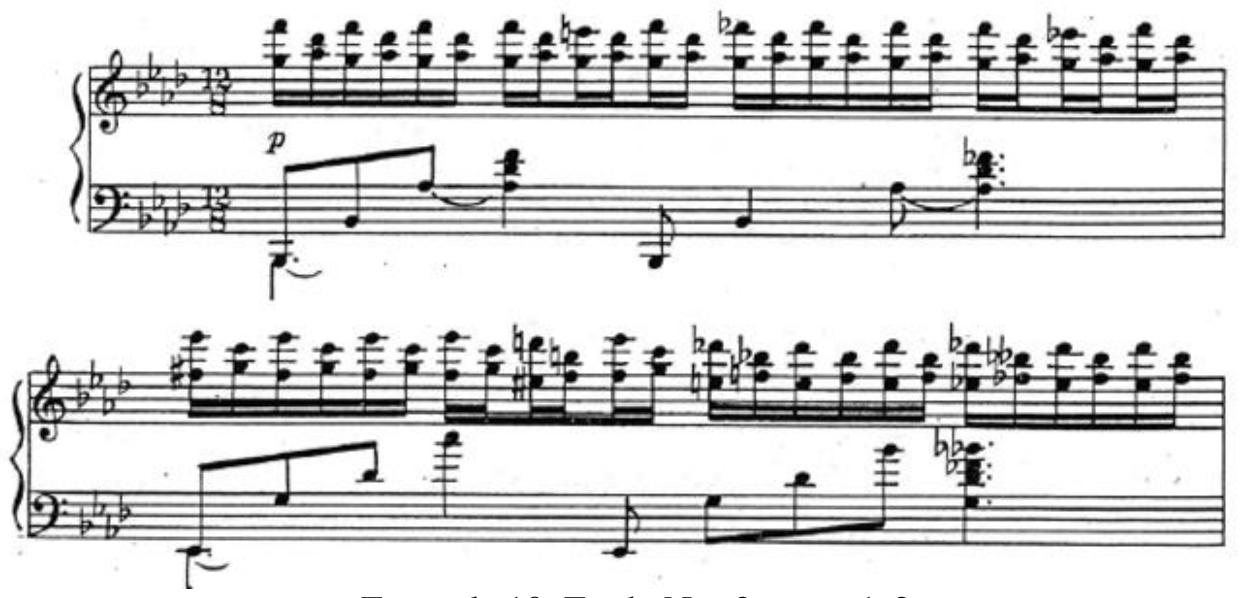

Example 10: Etude No. 2, mm. 1-2

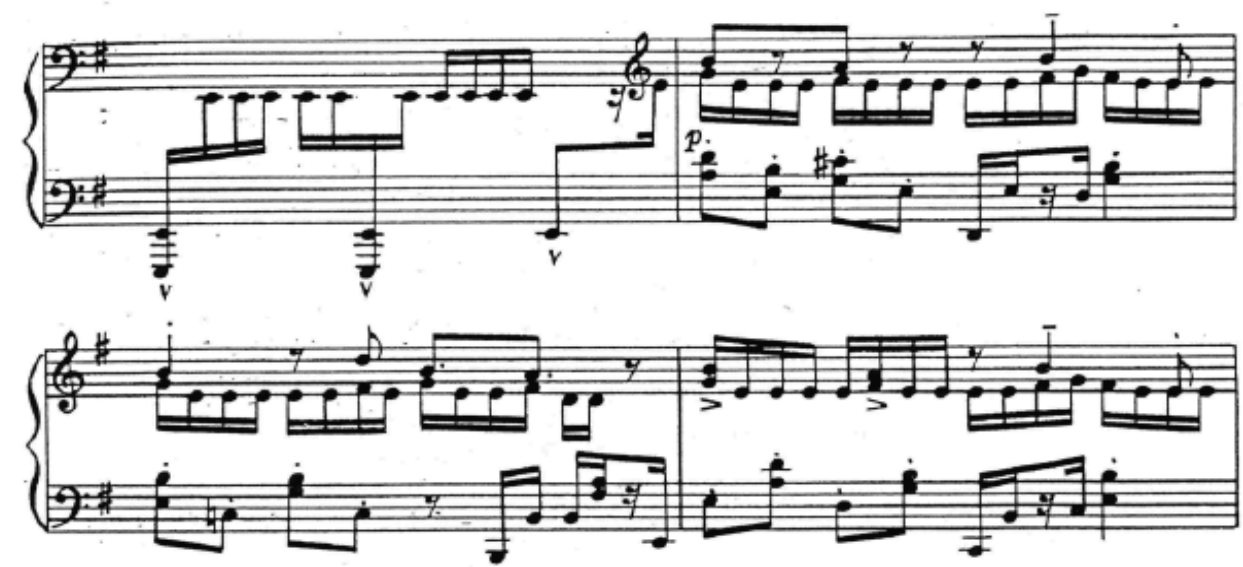

Example 11: Etude No. 3, mm. 7-10 


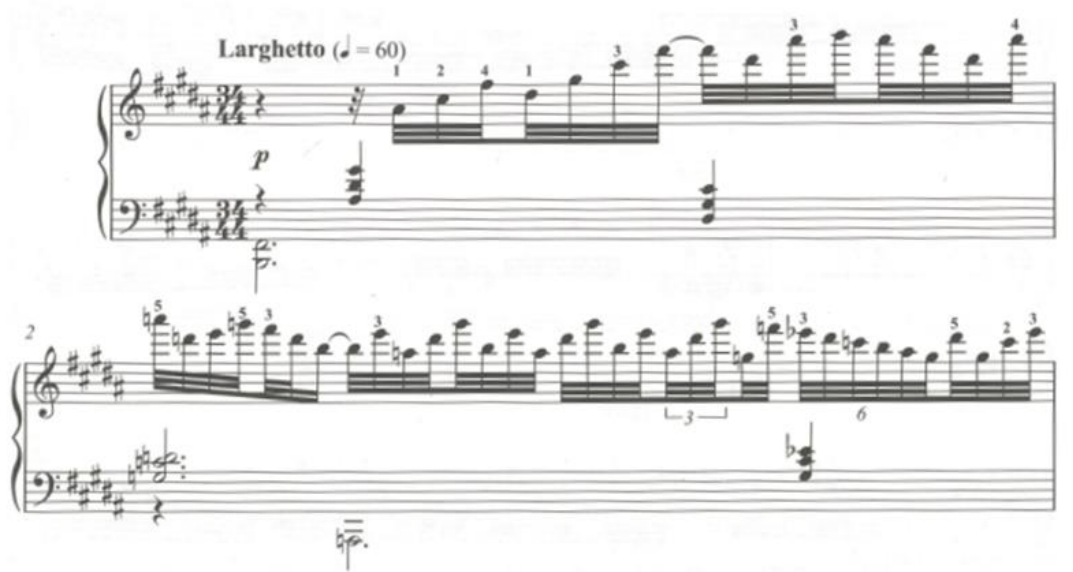

Example 12: Etude No. 4, mm. 1-2
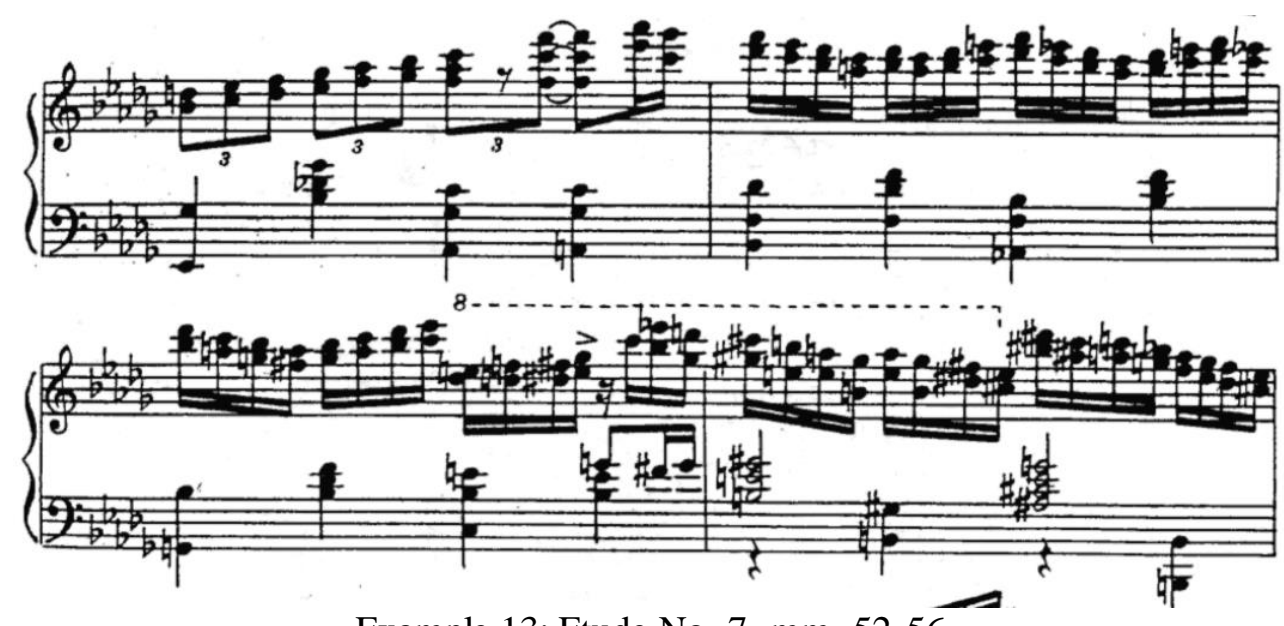

Example 13: Etude No. 7, mm. 52-56

Some passages show the influences of the previous masters that contributed to the etude genre, such as Chopin, Liszt, and Rachmaninoff. For instance, The B theme from Etude No. 3 (Toccatina) (Example 14) evokes Chopin's “Revolutionary” Etude, Op. 10, No. 12 (Example $15)$. 

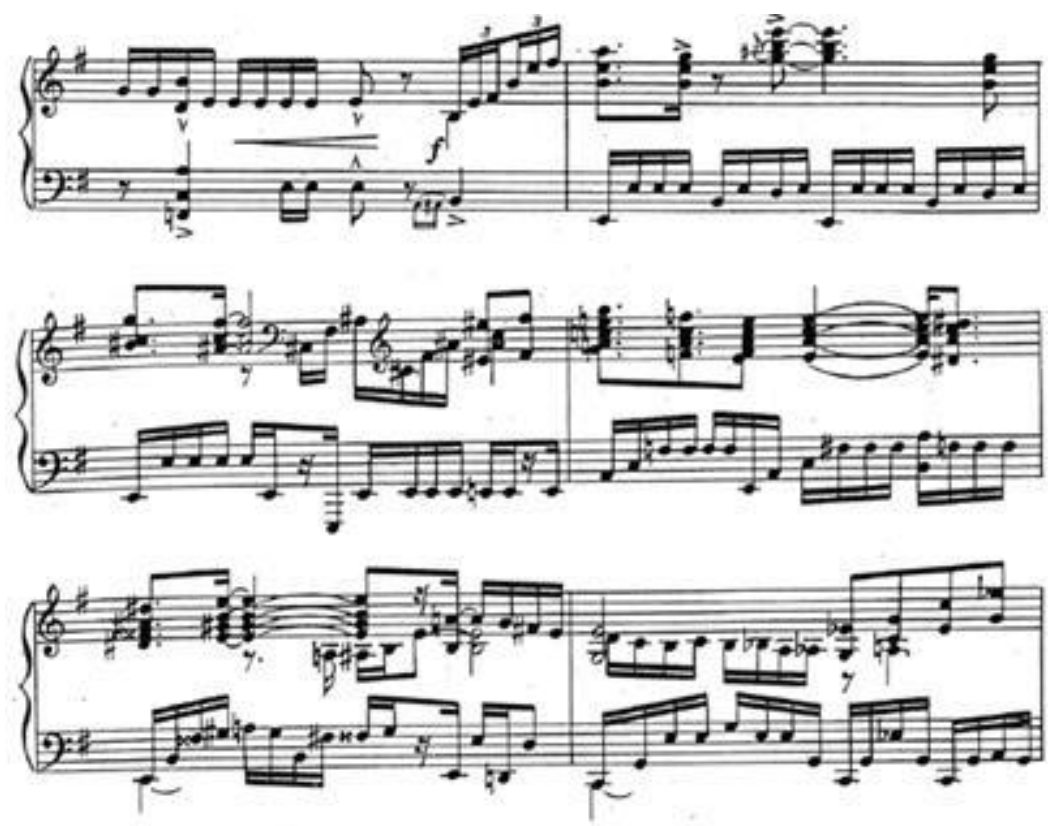

Example 14: Etude No. 3, mm. 23-28
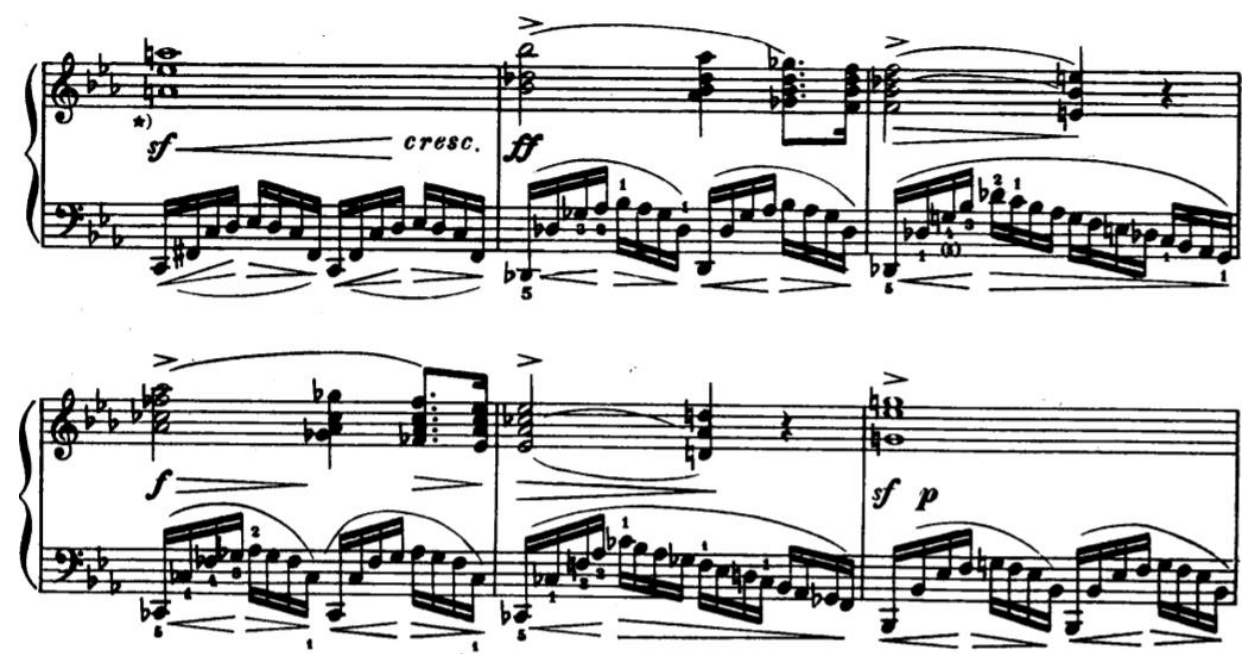

Example 15: Chopin's Etude, Op. 10, No. 12, mm. 64-69

The structure of the right hand in Etude No. 2 (Reverie) is reminiscent of similar material that was written by Rachmaninoff (Example 16). 

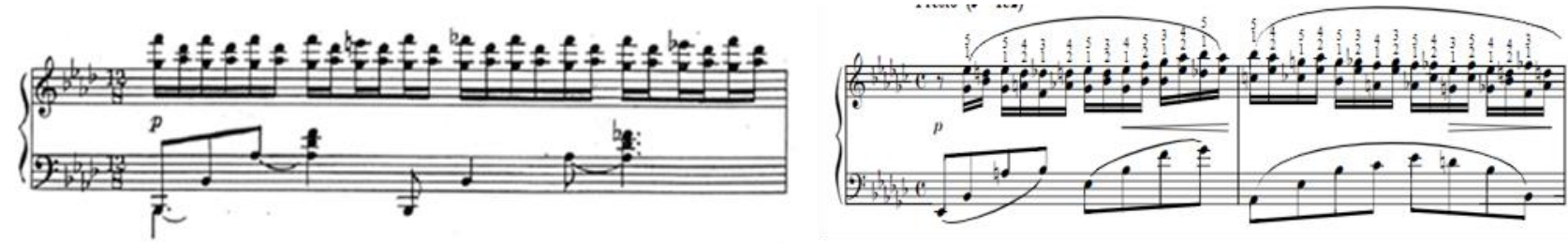

Example 16: Etude No. 2, mm. 1; Rachmaninoff's Prelude, Op. 23, No. 9, mm. 1-2

The following passage from Etude No. 3 (Example 17-a) presents a romantic and heroic character, ${ }^{113}$ which evokes Liszt or Rachmaninoff's works with frequent use of extended, massive chordal textures (Example 17-b).
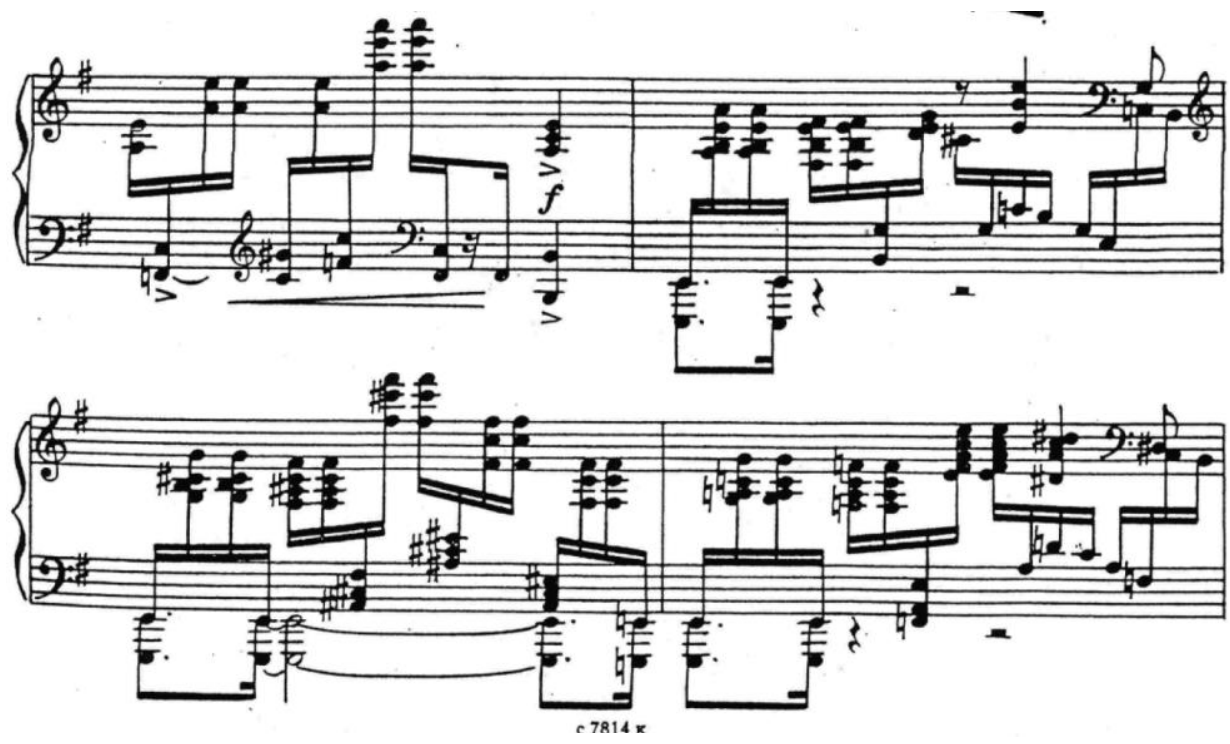

Example 17-a: Etude No. 3, mm. 51-54

${ }^{113}$ Abramova, "Synthesis of Jazzand Classical," 65. 

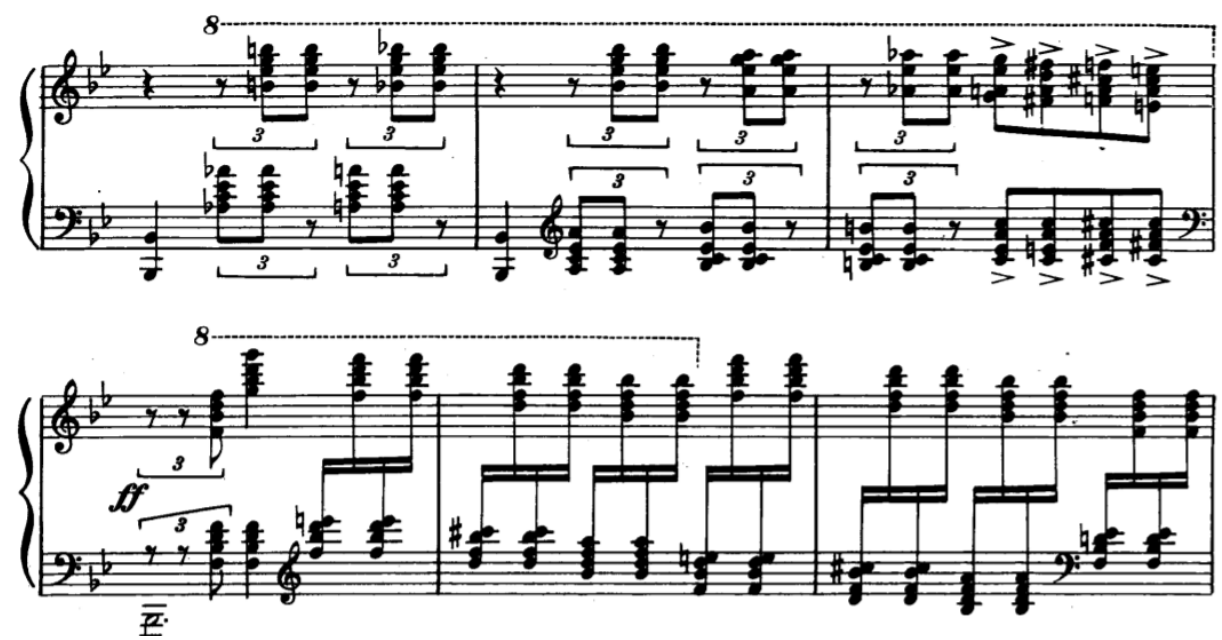

Example 17-b: Rachmaninoff's Piano Sonata No. 2, 3rd movement, mm. 288-293

Etude No. 4 (Reminiscence) shows influences from Debussy's music, with its chromaticism, parallel motion and pentatonic scales. No. 4 is the only one among the eight etudes that is written in alternating 3/4 and 4/4 time signatures. Its opening and ending materials are all based on the $\mathrm{F} \#$-major pentatonic scale (F\#-G\#-A\#-C\#-D\#). The pentatonic scale in the ending section is arranged into various groupings of notes moving in sequence (Examples 18-a and -b). With the music slowing down and the last note flowing away, the effect arouses an impressionistic image of the movement of water from its fluidity to tranquility.

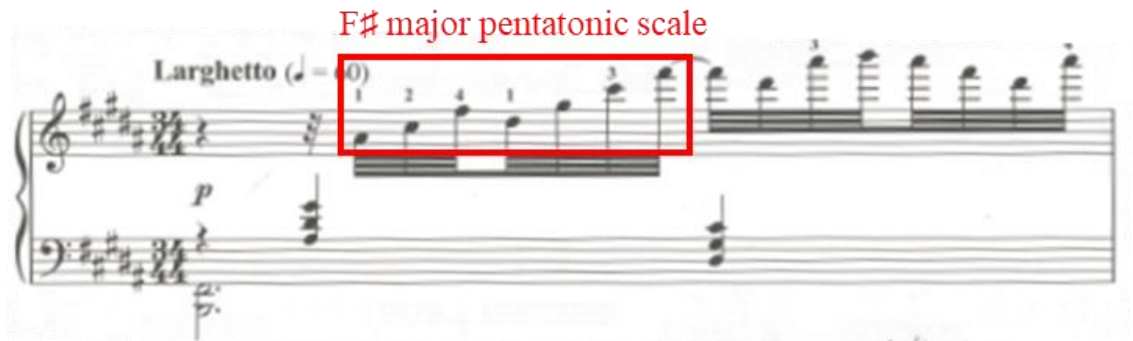

Example 18-a: Etude No. 4, mm. 1 

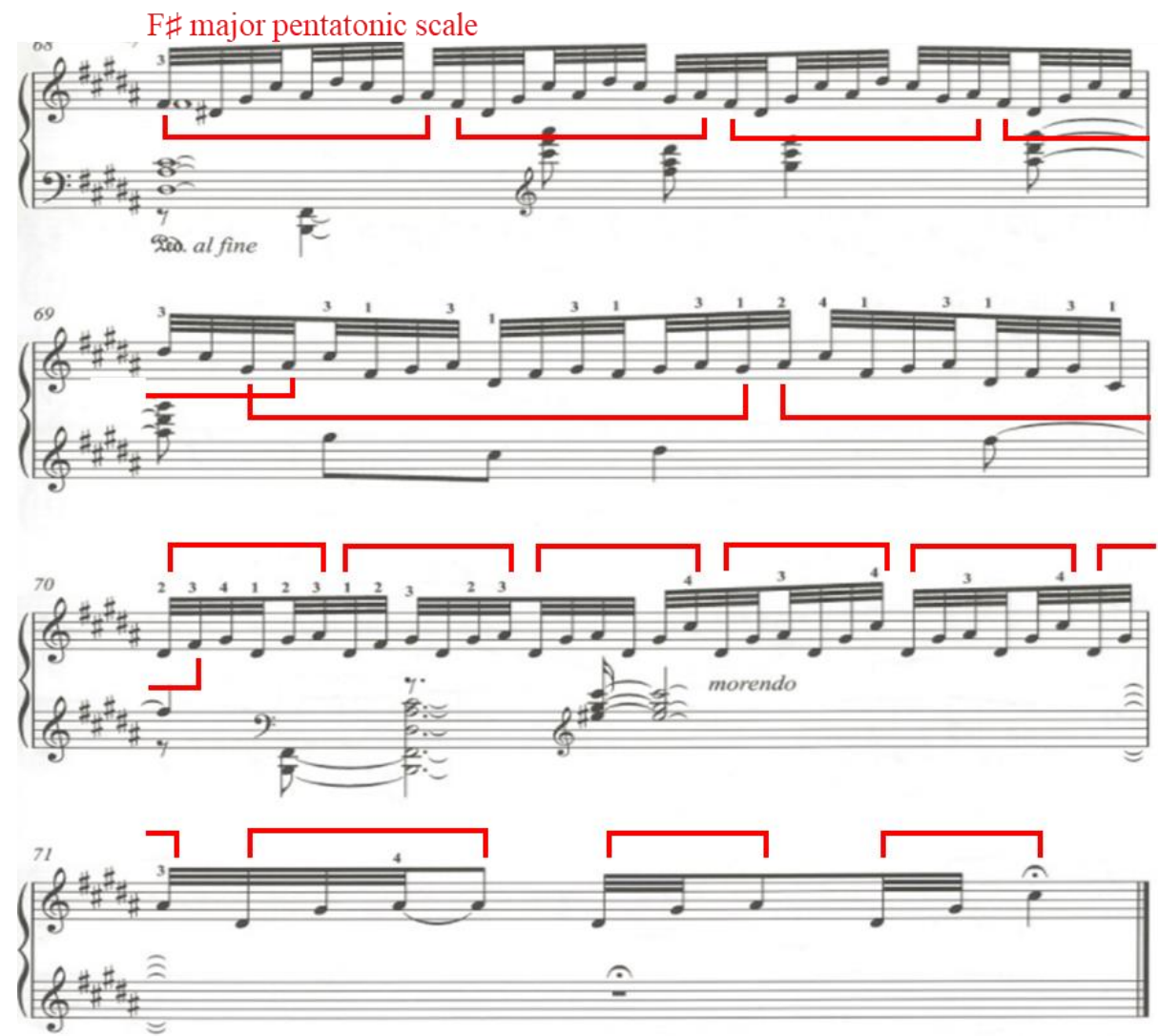

Example 18-b: Etude No. 4, mm. 68-71

\section{Jazz Techniques}

These eight etudes also incorporate a wide range of jazz techniques and styles. Among all the jazz scales (including modes, bebop, and whole-tone scales), blues and pentatonic scales are freely used in the set of etudes (see Example 19). One example is the pentatonic scale frequently used in Etude No. 4 (Reminiscence), as previously mentioned. Other examples include pentatonic scale and blues scale (Example 20) in Etude No. 6 (Pastoral). 

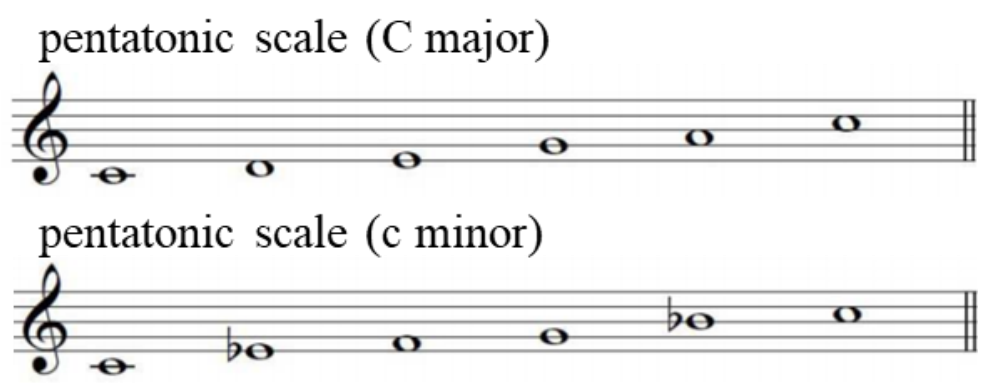

C blues scale

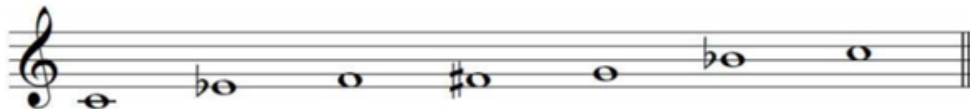

Example 19: $\mathrm{C}$ major and c minor pentatonic scales, and $\mathrm{C}$ blues scale

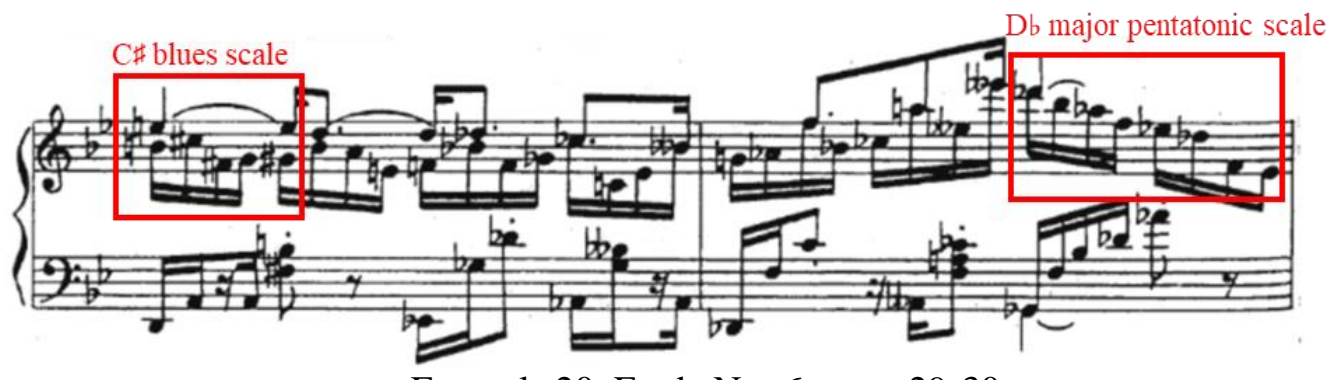

Example 20: Etude No. 6, mm. 29-30

Within the distinct rhythmic elements of jazz, accents and syncopation are extensively used in this set of etudes. For instance, in the Etude No. 1 (Prelude), two contrasting themes A and B (Example 21) are both made up of syncopated rhythmic patterns with accents.
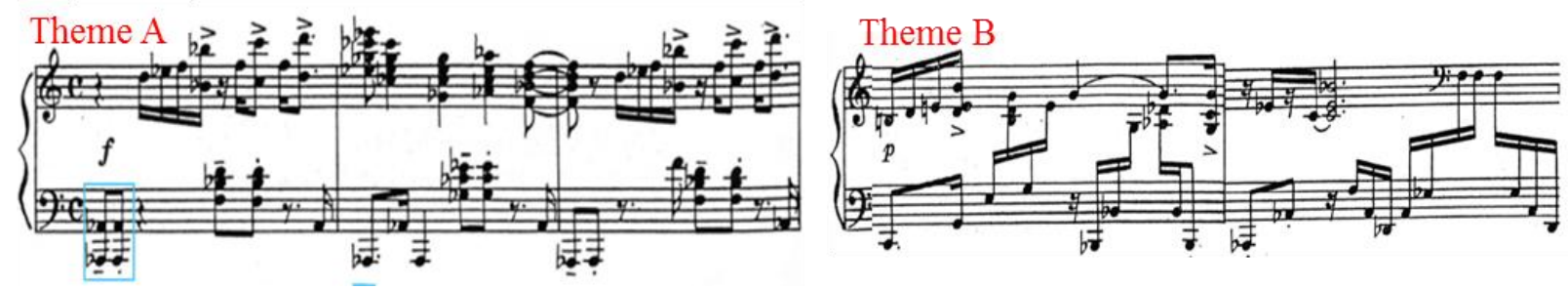

Example 21: Etude No. 1, A theme, mm. 1-3, and B theme, mm. 13-14 
Swing eighths, a rhythmic pattern based on triple division of the quarter note $\left(\cdot \bullet=\bullet^{3} \vec{\odot}\right),{ }^{114}$ is another rhythmic device commonly used in these etudes. It also can be notated with dotted-eighth and sixteenth notes $(\sqrt{\cdot}=\sqrt{5}) .{ }^{115}$ In Etude No. 7 (Intermezzo), both the introduction and theme A are built on swing eighths (Example 22).
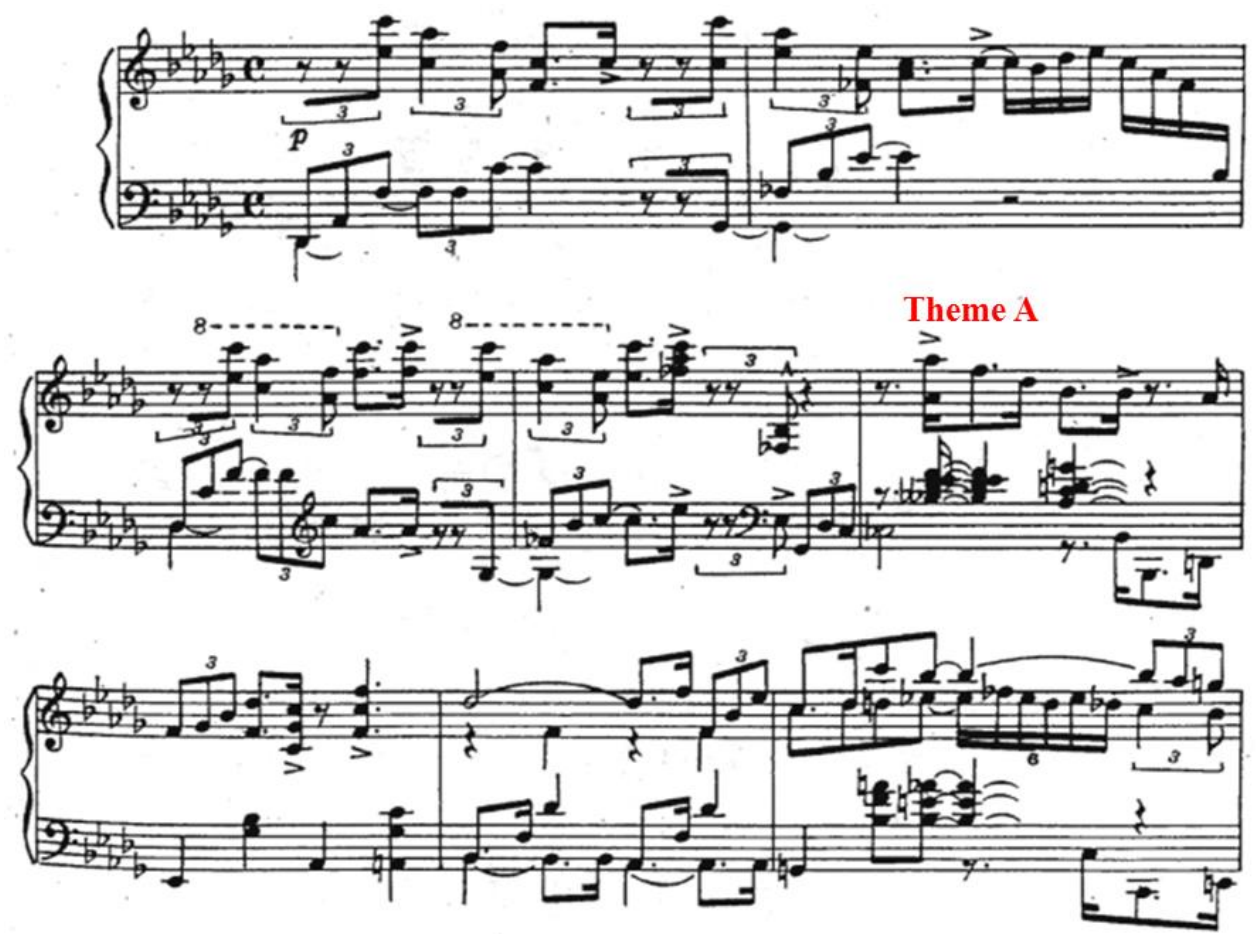

Example 22: Etude No. 7, mm. 1-8

The stride bass, which alternates bass notes with chords, is a common accompaniment figuration in jazz. The bass note of the stride can be two notes, octaves, or even tenths, ${ }^{116}$ and it is normally on the downbeat while the chord appears on the upbeat. However, this order may sometimes be reversed, placing the chord on the downbeat and bass note on the upbeat. Etude No. 7 (Intermezzo) illustrates the use of stride accompaniment (Example 23).

\footnotetext{
${ }^{114}$ Wang, "Fusion of Clas sical Virtuosity," 55.

${ }^{115}$ Wang, "Fusion of Clas sical Virtuosity," 55.

${ }^{116}$ Ye, "Solo Piano W orks," 11.
} 


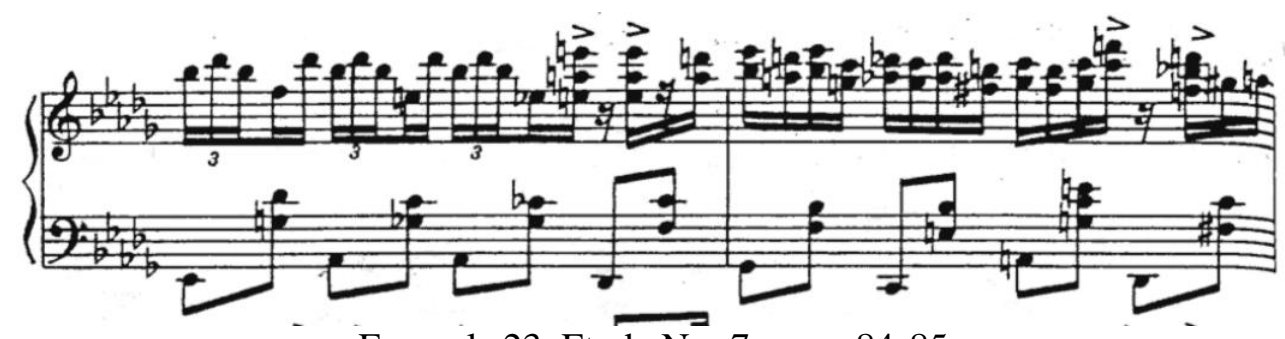

Example 23: Etude No. 7, mm. 84-85

Quartal and Quintal Harmony, sonorities derived from stacked fourths or fifths (perfect, augmented, or diminished), are considered unorthodox chords, emphasizing the predominance of sound or the structure of musical harmony, rather than its function. ${ }^{117}$ In classical music, such harmonies are explored by various composers, for example Richard Wagner in his "Tristan chord" (Fদ-B $4-D \#-G \#)$ and Alexander Scriabin with his "Mystic Chord" (C-F\#-Bb-E-A-D). Many jazz pianists, such as McCoy Tyner, Herbie Hancock, and Chick Corea, use these chords in their works. ${ }^{118}$ Etude No. 4 (Reminiscence) illustrates the use of quartal harmonies (Example 24).

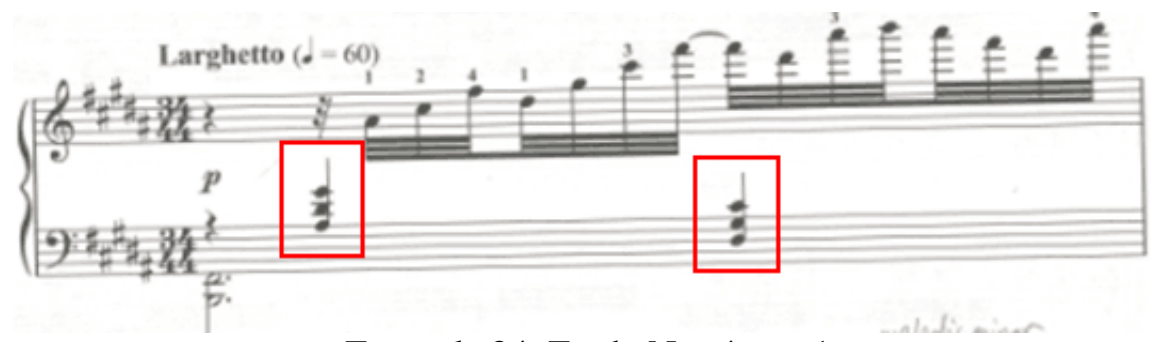

Example 24: Etude No. 4, m. 1

Boogie-woogie is characterized by forceful, repeated bass figuration, almost always using the 12-bar format of the blues, remaining an enduring accompaniment style in blues, rock and

\footnotetext{
${ }^{117}$ Robert Ericks on, Sound Structure in Music. (Los Angeles, CA: University of California Press, Ltd., 1975), 94-95.

${ }^{118}$ Creighton, "A Man of Two Worlds," 64.
} 
roll, and rhythm and blues. ${ }^{119}$ The basic 12-bar blues harmonic scheme is based on the I, IV, and $\mathrm{V}$ chords of the key. An example in $\mathrm{C}$ major is shown below (Example 25):

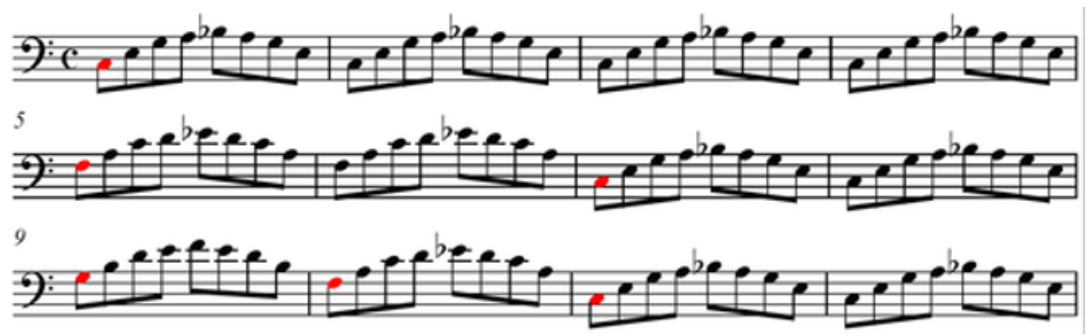

\begin{tabular}{|c|c|c|c|c|c|c|c|c|c|c|c|}
\hline 1 & 2 & 3 & 4 & 5 & 6 & 7 & 8 & 9 & 10 & 11 & 12 \\
\hline I & I & I & I & IV & IV & I & I & V & IV & I & I \\
\hline
\end{tabular}

Example 25: 12-bar blues harmonic scheme in $\mathrm{C}$ major

The basic 12-bar blues may be presented with variations. Etude No. 5 (Raillery) is a typical example that is written in boogie-woogie style and with the 12-bar blues harmonic scheme (Example 26). Compared to the example shown above, the harmonic language in Raillery is very complex due to the jazz idiom. It follows the logic of the 12-bar blues chord progression, but with varied harmonies and phrase lengths.

${ }^{119}$ Ye, "Solo Piano W orks," 12. 


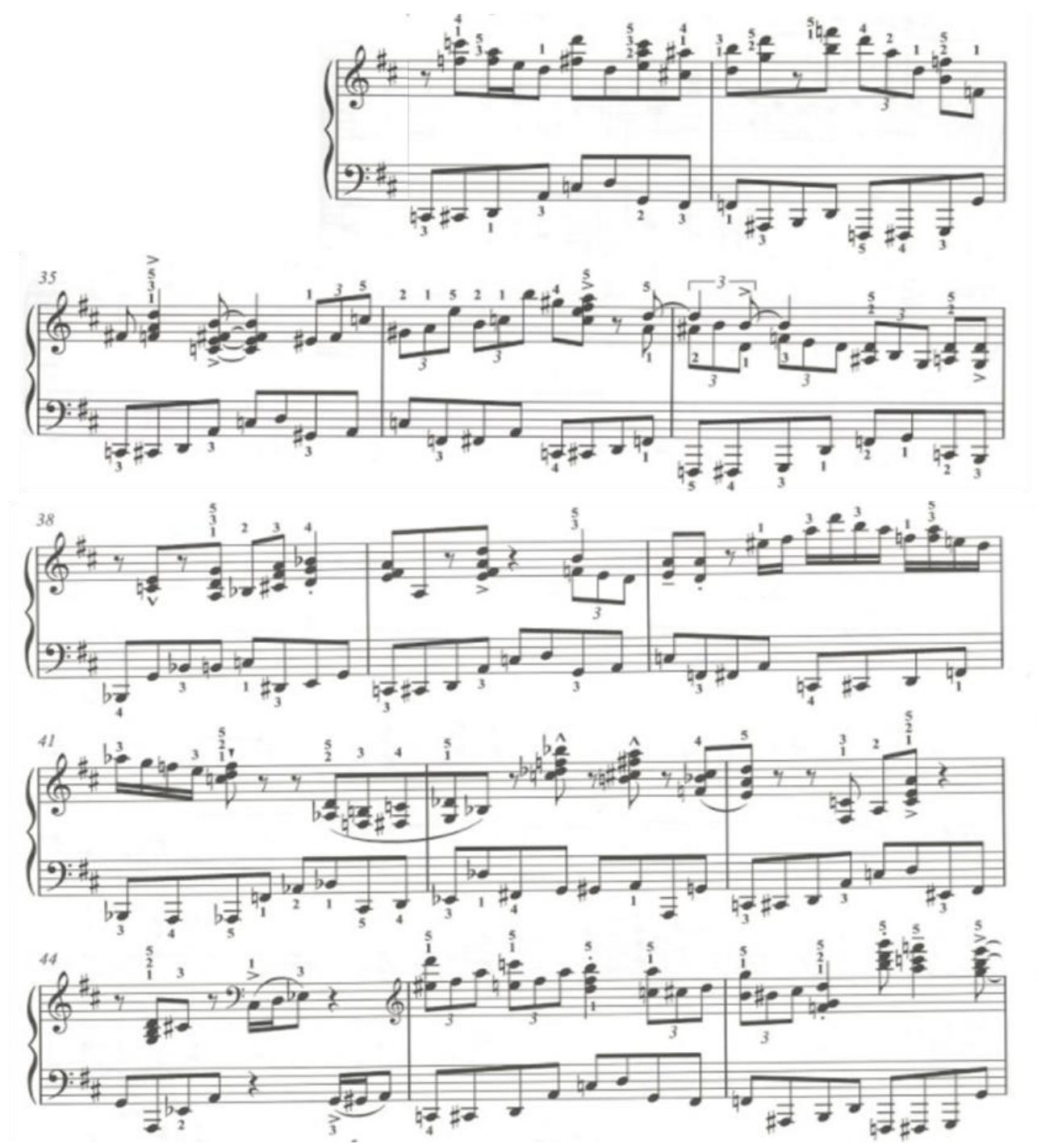

Example 26: Etude No. 5, mm. 32-47 


\subsection{Analysis of Compositional Principles in Two Etudes}

\subsubsection{Analysis of Etude No. 2 (Reverie)}

The title of this etude, "Reverie," suggests a dreamy and flowing state about the music. The etude is cast in ternary form. It is a piece that inspires contrasts in two different styles-romantic style in the A section and jazz style in the B section. This contrasting effect also appears in other etudes, such as No. 3 (Toccatina) which embodies two different styles: jazz idiom in the A section and romantic style in the B section; and No. 4 (Reminiscence) with combined jazz and impressionist styles. Etude No. 2 is cast in ternary form. The diagram is shown below:

\begin{tabular}{|l|l|l|l|}
\hline Part & I & II & III \\
\hline Section & A & B & A' \\
\hline Subsection & mm. 1-22 & mm. 23-119 & mm. 120-138 \\
\hline Phrases & $\begin{array}{l}\text { a (mm. 1-8) } \\
\text { a' (mm. 9-18) } \\
\text { closing material } \\
\text { (mm. 19-22) }\end{array}$ & $\begin{array}{l}\text { Introduction (mm. 23-26) } \\
\text { b (mm. 27- 34) transition (mm. 35-42) } \\
b^{\prime}(\mathrm{mm} .43-50) \text { transition (mm. 51-58) } \\
\text { c (mm. 59-74) c' (mm. 75-90) } \\
\text { closing material (mm. 91-119) }\end{array}$ & coda (mm. 130-138) \\
\hline
\end{tabular}

Chart 5: Etude No. 2 - form

The A section (mm. 1-22) includes a rapid double-note passage, in which the right hand alternates large intervals with small intervals in a chromatic top line (Example 27). This section hints at a classical technique: the left hand displays mostly arpeggio figures while the right hand presents chords with a hint of the theme in the top line. Lyric and tender in character, this section is melodious and flowing, which corresponds to the title. 


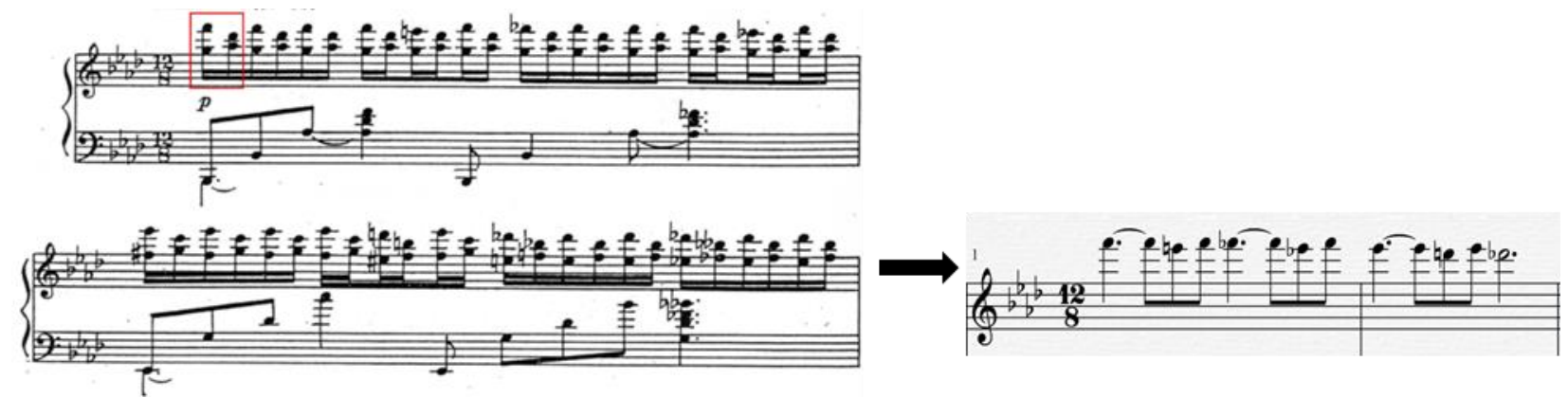

Example 27: Etude No. 2, mm. 1-2

The A section consists of two large phrases in similar manner. The first phrase is eight bars long and the second one is extended by two more bars. The right hand maintains the same pattern throughout the section, while the accompaniment in the second phrase (mm. 9-18) differs from the first (mm. 1-8) by adding dotted rhythm and $16^{\text {th }}$ figures. Because the first phrase starts with the ii 7 chord and the second phrase with the V chord, we do not immediately perceive a strong sense of tonality. A common jazz chord progression appears in $\mathrm{m}$. 18 for establishing the key center; the home key of $\mathrm{Ab}$ major is confirmed at m. 19 (Example 28). In the closing section (mm. 19-22), the rhythm of the last two measures (mm. 21-22) is temporarily switched to create a hemiola effect. The right hand employs descending chromatic motion, while the left hand holds the tonic pedal point, then moves down a half step to $\mathrm{G}$. 


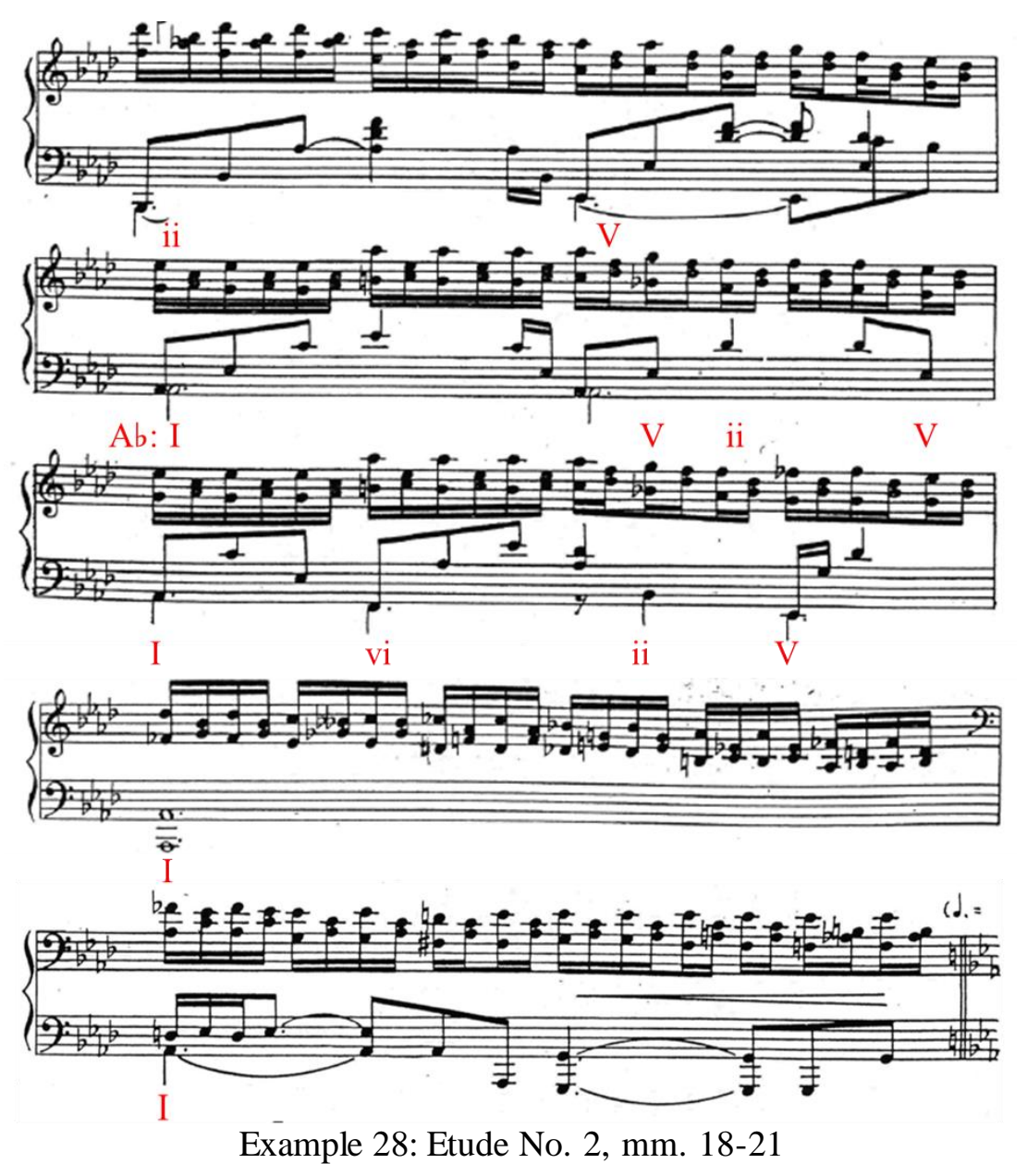

The alternating double-note texture in the A section follows the classical-romantic stylistic tradition. The A section explores fairly obvious technical difficulties and is quite lyrical in style.

The contrasting B section (mm. 23-119) features rich jazz elements. The short introduction (mm. 23-26) opens with a pentatonic scale followed by Dorian mode as the Ab changes to A (Example 29).

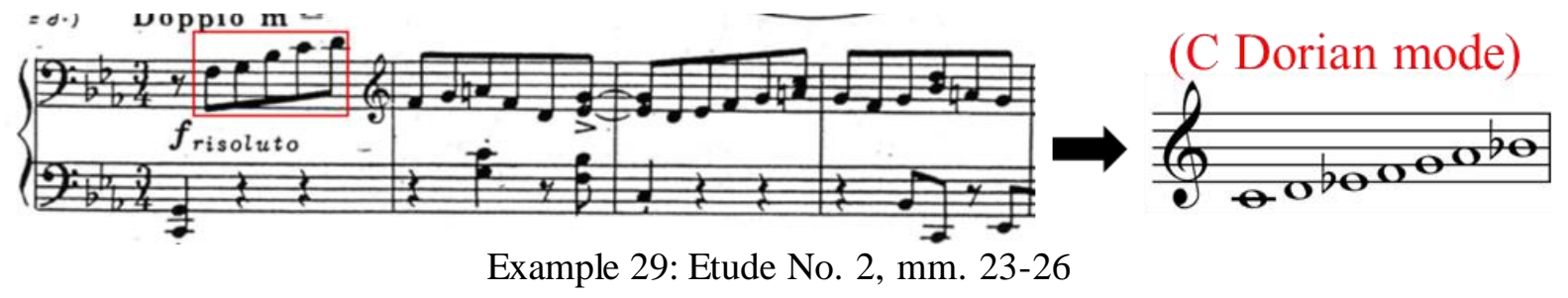


The B section (mm. 23-119) is divided into three subsections. The first subsection consists of two large phrases that we can call b and b'. They reveal similar structures, as each is made up of eight-bar phrases (4+4) with a transition passage. In theme b (mm. 27-34), the right hand has two lines - the melody is in the top while the alto presents tremolo figures and a melodic-second motif that appears and develops successively in the two transitions (Example 30); the left hand features syncopated rhythm. The b' material (mm. 43-50) is slightly varied in the top melody and includes blues scales in the alto (Example 31).
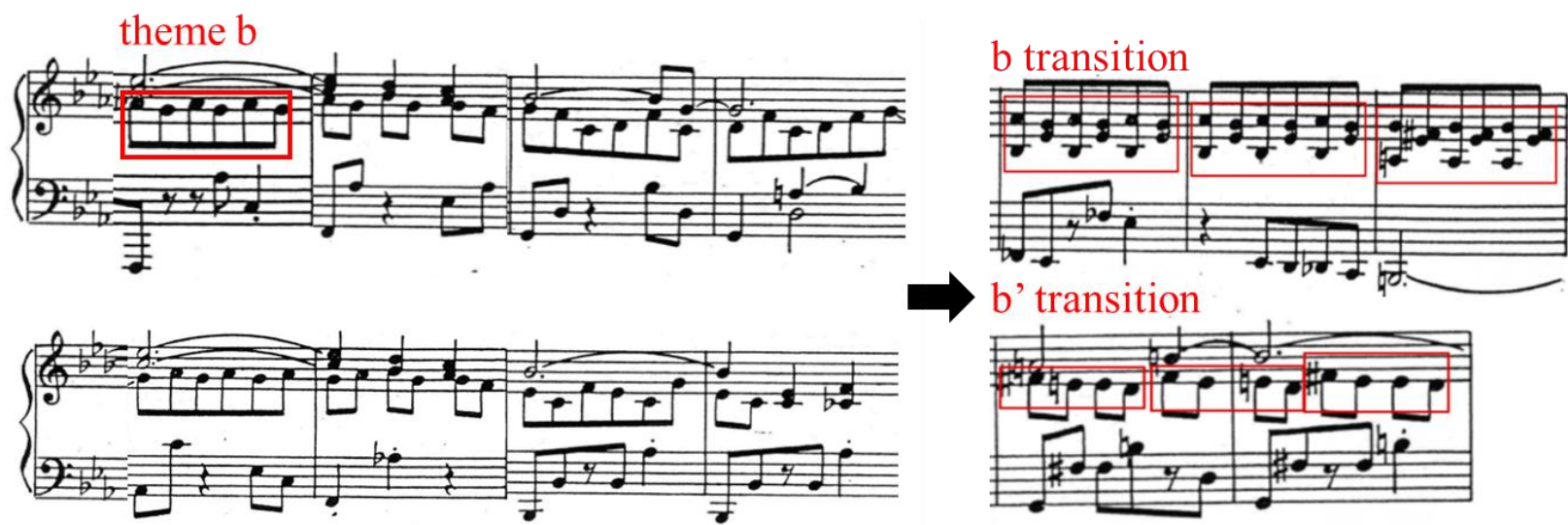

Example 30: Etude No. 2, theme b (mm. 27-34)/tremolo figure in b transition, mm. 35-37/descending melodic 2nd in b' transition, mm. 51-52

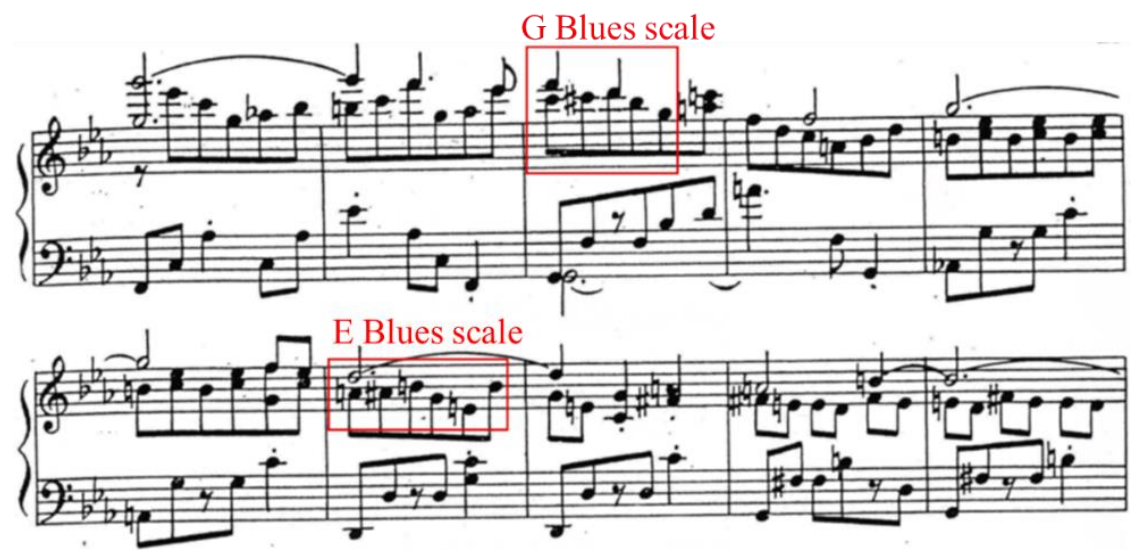

Example 31: Etude No. 2, b’ section, mm. 43-50 
The following section presents new melodic material, divided into two parallel large phrases labeled as c (mm. 59-74) and c' (mm. 75-90), as shown in Example 32. These phrases begin similarly, with dominant chord, G major; the left hand features ascending melodic octaves.
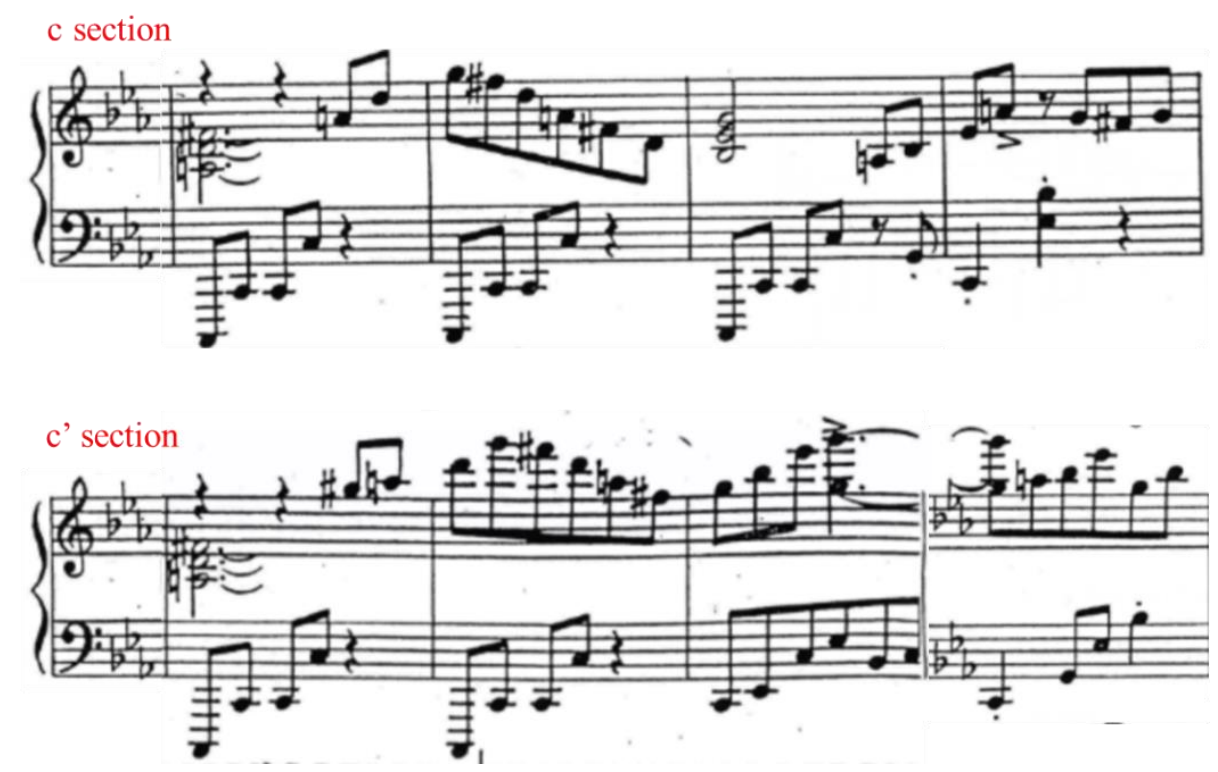

Example 32: Etude No. 2, beginning of c section (mm.59-62) and c' section (mm. 75-78)

Functioning as a transition that prepares the return to the A' section, the third section (mm. 91119) returns to double-note tremolo by phrases of $4+4+6+7+8$ bars, foreshadowing the return of the A section. The last eight bars (mm. 112-119) correspond to the end of the A section; they also display a chromatic approach, in which the alternating double-note melody moves down by half steps to lead us back to the beginning of the A' section (mm. 119-120, showing a top line: F\# D--FG $\mathrm{Db}$ and an alto line: $\mathrm{G}$ A--Gদ $\mathrm{Ab}$ ). The left hand reveals a D-major chord over E bass (mm. 109 114 ) at the beginning, and then only keeps a major third from D to F\# (Example 33). 


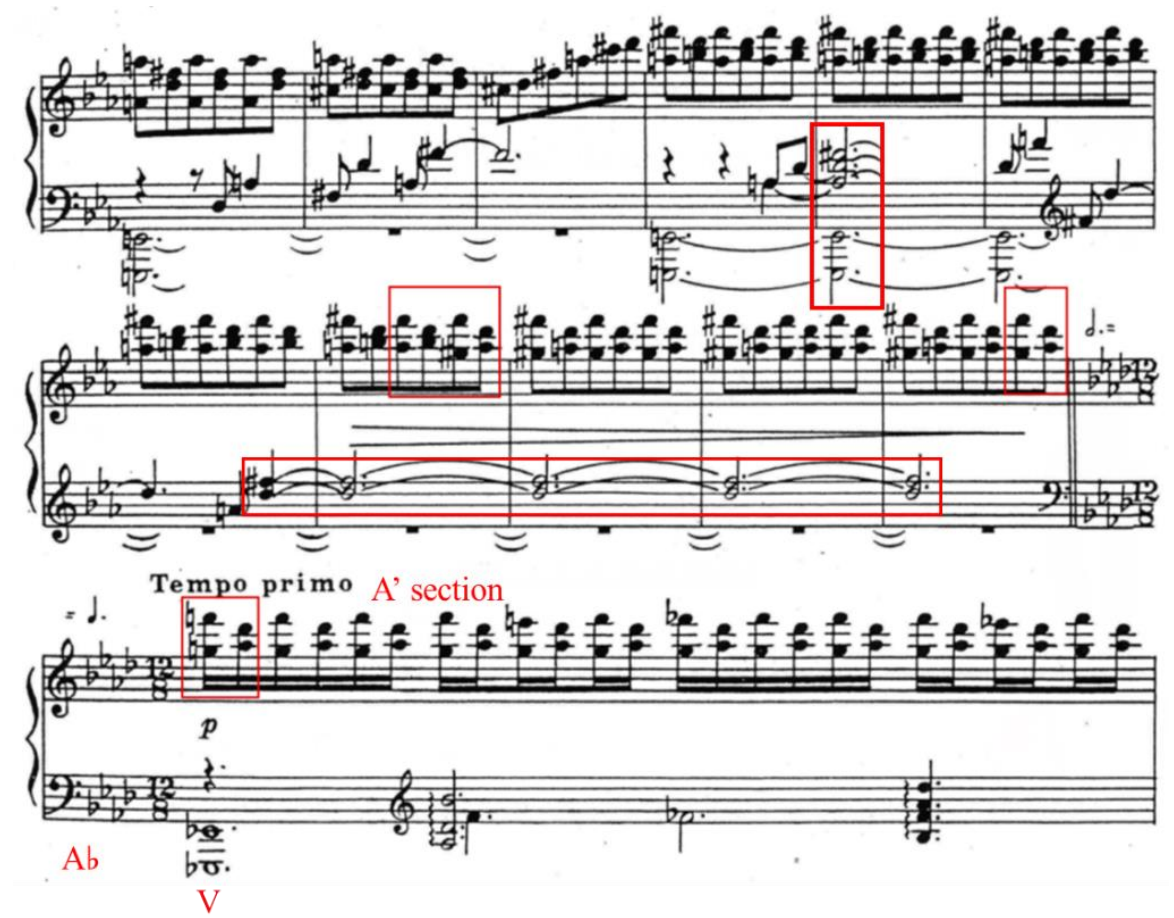

Example 33: Etude No. 2, mm. 109-120

Beginning with $\mathrm{Eb}$, the dominant chord of $\mathrm{Ab}$ major, the $\mathrm{A}^{\prime}$ section (mm. 120-138) is an altered repeat of the A section. The left hand uses rolled chords instead of an arpeggiated figure. As in the A section, a ii- $\mathrm{V}$ progression appears at the end of the first section for establishing the key; the home key of Ab major is confirmed in m. 130. The coda (mm. 130-138) is based on the closing material (mm. 19-22), which also contains a descending hemiola passage (m. 133). The last four bars feature quartal chords and extended chords. In the last measure, the tonic ninth chord and then a thirteenth chord substitute for the tonic triad (Example 34). In the 20 $0^{\text {th }}$ century, especially in jazz and popular music, instead of a cadence ending on the tonic triad at the end of a piece, ninth chords often appear as elaborations of simpler chords. ${ }^{120}$

\footnotetext{
${ }^{120}$ Julian Rushton, "Ninth chord," Grove Music Online, Jan. 20, 2001, acces sed Apr. 06, 2019. http://www.oxfordmusiconline.com/grovemusic/view/10.1093/gmo/9781561592630.001.0001/omo 9781561592630-e-0000019979.
} 

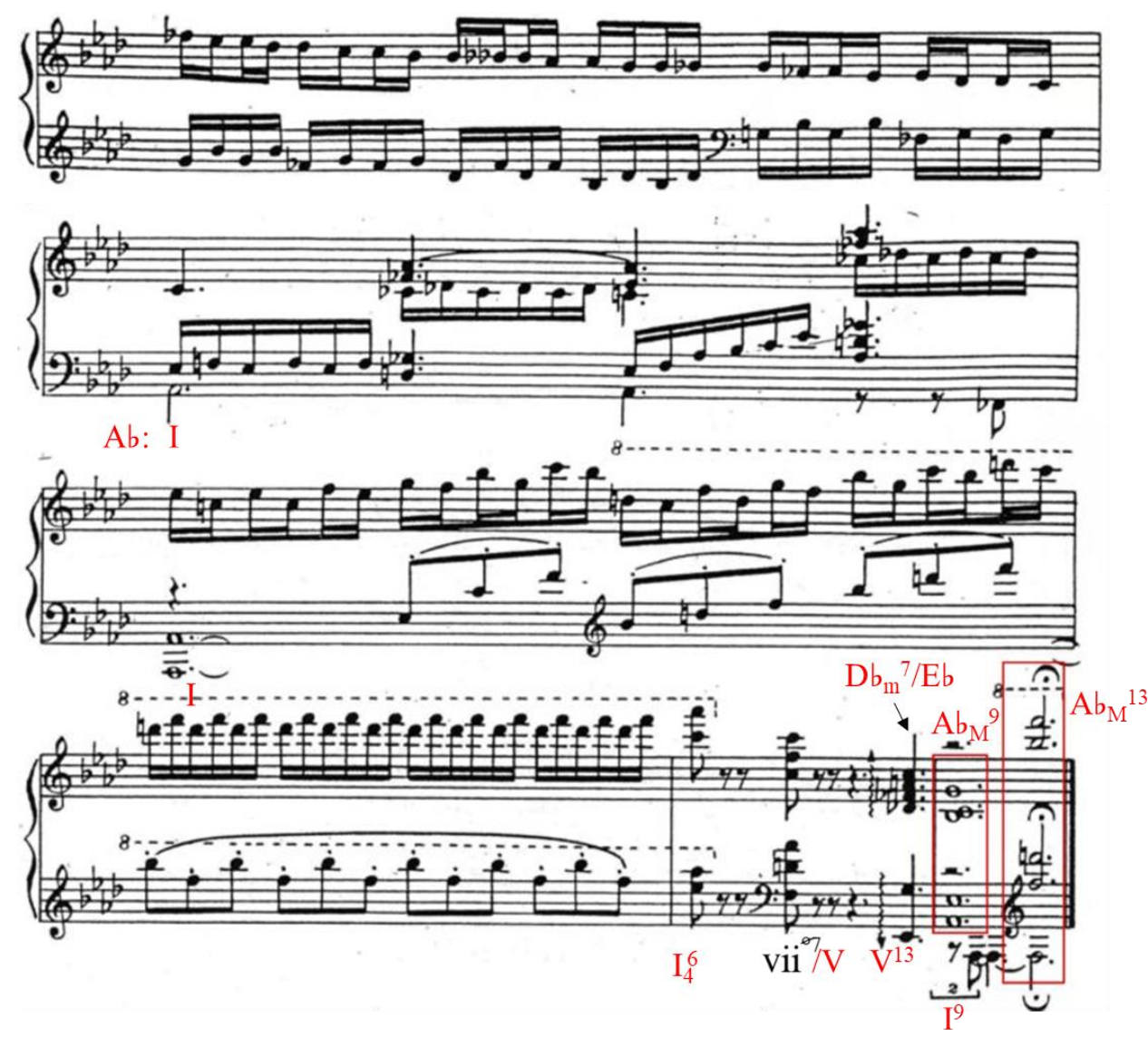

Example 34: Etude No. 2, mm. 133-138 


\subsubsection{Analysis of Etude No. 8 (Finale)}

As the last piece in Op. 40, No. 8 (Finale) is vibrant and energetic in character, similar to No. 1 (Prelude), No. 3 (Toccatina) and No. 5 (Raillery). Furthermore, Kapustin employs similar melodic material that was used in Etude No. 2 (Reverie) ${ }^{121}$ and makes stylistic reference to the coda in No. 1 (Prelude). Recalling some of the earlier etudes during the finale helps to unify the entire set.

Kapustin writes No. 8 in AABC form; comparing to the previous etudes, we observe more complexity and extended length in each section. The diagram of the formal structure appears below:

\begin{tabular}{|c|c|c|c|c|c|c|c|c|c|c|c|}
\hline Part & & \multicolumn{8}{|c|}{ I } & \multirow{2}{*}{\multicolumn{2}{|c|}{ Transition }} \\
\hline Section & Intro & \multicolumn{2}{|c|}{$\overline{\mathbf{A}}$} & \multicolumn{2}{|c|}{$\overline{\mathbf{A}}$} & \multicolumn{2}{|c|}{$\overline{\mathbf{B}}$} & \multicolumn{2}{|c|}{$\mathbf{C}$} & & \\
\hline Subsection & mm. 1-4 & \multicolumn{2}{|c|}{ mm. 5-25 } & \multicolumn{2}{|c|}{ mm. 25-46 } & \multicolumn{2}{|c|}{ mm. 47-62 } & \multicolumn{2}{|c|}{ mm. 63-74 } & \multicolumn{2}{|c|}{ mm. $75-90$} \\
\hline Phrases & $2+2$ & $\begin{array}{l}\text { a (5- } \\
12)\end{array}$ & $\begin{array}{c}a^{\prime}(13- \\
25)\end{array}$ & $\begin{array}{c}\text { a (25- } \\
32)\end{array}$ & $\begin{array}{c}\text { a" (33- } \\
45)\end{array}$ & $\begin{array}{c}\mathrm{b}(47- \\
54)\end{array}$ & $\begin{array}{c}\mathrm{b}^{\prime}(55- \\
62)\end{array}$ & $\begin{array}{c}\mathrm{c}(63- \\
70)\end{array}$ & $\begin{array}{c}c^{\prime}(71- \\
74)\end{array}$ & & \\
\hline Key & $\mathrm{f}$ & \multicolumn{2}{|c|}{$\mathrm{f}$} & \multicolumn{2}{|c|}{$\mathrm{f}$} & \multicolumn{2}{|c|}{ Eb-c-g } & \multicolumn{2}{|c|}{$\mathrm{Eb}-\mathrm{Bb}$} & \multicolumn{2}{|c|}{ V Pedal } \\
\hline motive & $\begin{array}{l}\text { C-D- } \\
\text { Eb-D }\end{array}$ & C-D & $\begin{array}{l}\text { F-Eb, } \\
\text { Bb-Ab- } \\
\text { G }\end{array}$ & C-D & $\begin{array}{l}\text { F-G- } \\
\text { Fb-A- } \\
\text { B }\end{array}$ & $\begin{array}{l}\mathrm{Eb}-\mathrm{D}- \\
\mathrm{C}-\mathrm{Bb}\end{array}$ & $\begin{array}{l}\text { G-F- } \\
\text { Eb-D }\end{array}$ & & & & \\
\hline Part & & \multicolumn{8}{|c|}{ II } & & \\
\hline Section & Intro & \multicolumn{2}{|c|}{$\overline{\mathbf{A}}$} & \multicolumn{2}{|c|}{$\overline{\mathbf{A}}$} & \multicolumn{2}{|c|}{$\overline{\mathbf{B}}$} & \multicolumn{2}{|c|}{$\bar{C}$} & \multicolumn{2}{|c|}{ coda } \\
\hline subsection & $\begin{array}{c}\text { mm. 91- } \\
94\end{array}$ & \multicolumn{2}{|c|}{ mm. 95-116 } & \multicolumn{2}{|c|}{ mm. 117-132 } & \multicolumn{2}{|c|}{ mm. $133-148$} & \multicolumn{2}{|c|}{ mm. 149-168 } & \multicolumn{2}{|c|}{ mm. $169-192$} \\
\hline Phrases & $2+2$ & $\begin{array}{c}\text { a (94- } \\
102)\end{array}$ & $\begin{array}{c}\text { a' } \\
\text { (103- } \\
116)\end{array}$ & $\begin{array}{c}\mathrm{a} \\
(117- \\
124)\end{array}$ & $\begin{array}{c}\text { a" } \\
(125- \\
132)\end{array}$ & $\begin{array}{c}\text { b (133- } \\
140)\end{array}$ & $\begin{array}{c}\text { b' } \\
(141- \\
148)\end{array}$ & $\begin{array}{c}\mathrm{C} \\
(149- \\
156)\end{array}$ & $\begin{array}{c}c^{\prime} \\
(157- \\
168)\end{array}$ & $\begin{array}{c}\text { Code part } \\
1(169- \\
180)\end{array}$ & $\begin{array}{c}\text { Code part } \\
2(181- \\
192)\end{array}$ \\
\hline key & $\mathrm{f}$ & \multicolumn{2}{|c|}{$\mathrm{f}$} & \multicolumn{2}{|c|}{$\mathrm{f}$} & \multicolumn{2}{|c|}{ F-d-g } & \multicolumn{2}{|c|}{ F-C } & \multicolumn{2}{|c|}{$\mathrm{f}$} \\
\hline motive & $\begin{array}{c}\text { C-D-E- } \\
\text { D }\end{array}$ & C-D & $\begin{array}{l}\text { F-Eb, } \\
\text { Ab-G }\end{array}$ & C-D & $\begin{array}{c}\text { F-Eb- } \\
\mathrm{Db}\end{array}$ & $\begin{array}{l}\text { F-E-D- } \\
\text { C }\end{array}$ & A-G & & & & \\
\hline
\end{tabular}

Chart 6: Etude No. 8 - form

${ }^{121}$ Okamoto, "Kapustin's Eight Concert Etudes,” 91. 
The four-bar introduction opens with a strong and intensely rhythmic character, which recalls similar opening styles in Etudes No. 1 (Prelude) and No. 3 (Toccatina). The pervasive syncopated rhythm with accents on weak beats in the opening often conveys that the rhythmic auditory effect prevails over the melodic effect. The melodic line is simple and successively built on the major and minor second (Example 35). Intervals of a second create an important motive that develops consistently throughout the piece.

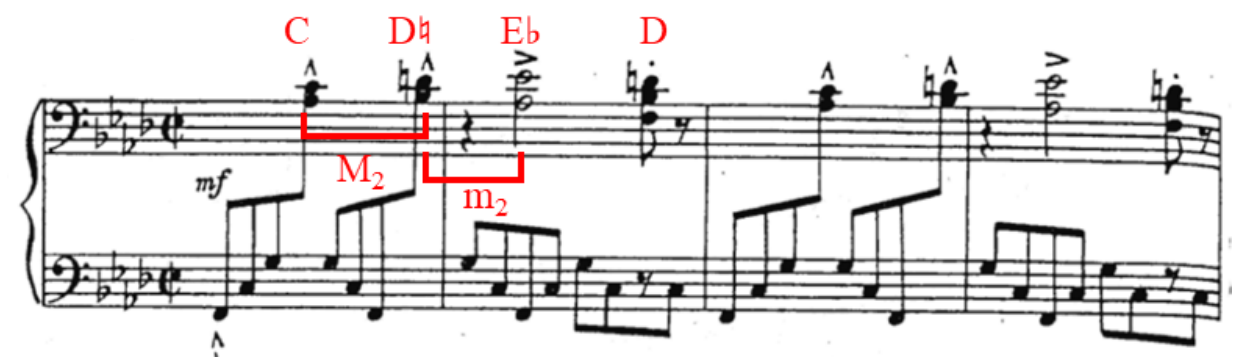

Example 35: Etude No. 8, introduction, mm. 1-4

The first A section in Part I (mm. 5-25) consists of two large phrases. The first phrase (Example 36-a) is built on the first two notes from the introduction (C-D) in 4+4 phrases. The second phrase (Example 36-b) contains the main melody ( $\mathrm{F}-\mathrm{Eb}, \mathrm{Bb}-\mathrm{A} b-\mathrm{G})$. Intervals of seconds not only play a primary role in the main melody, but also form scale patterns that unify the melody.

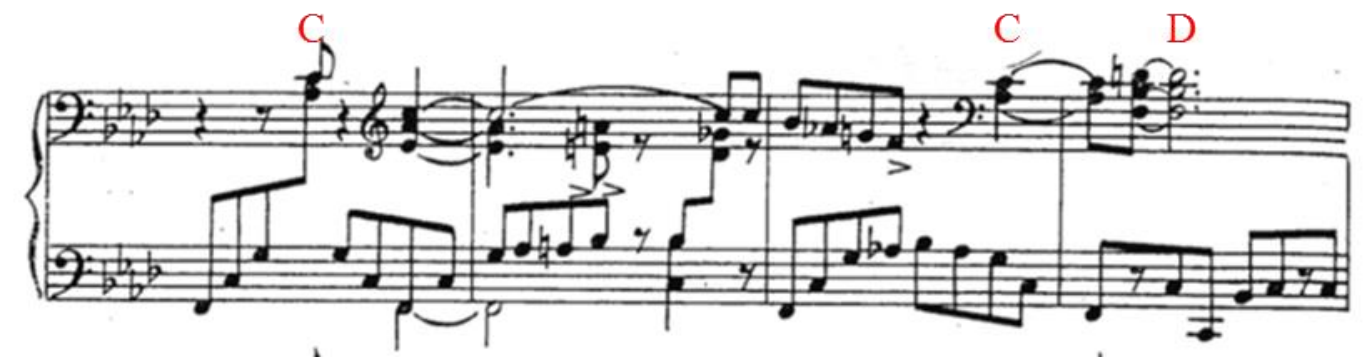

Example 36-a: Etude No. 8, mm. 5-8 


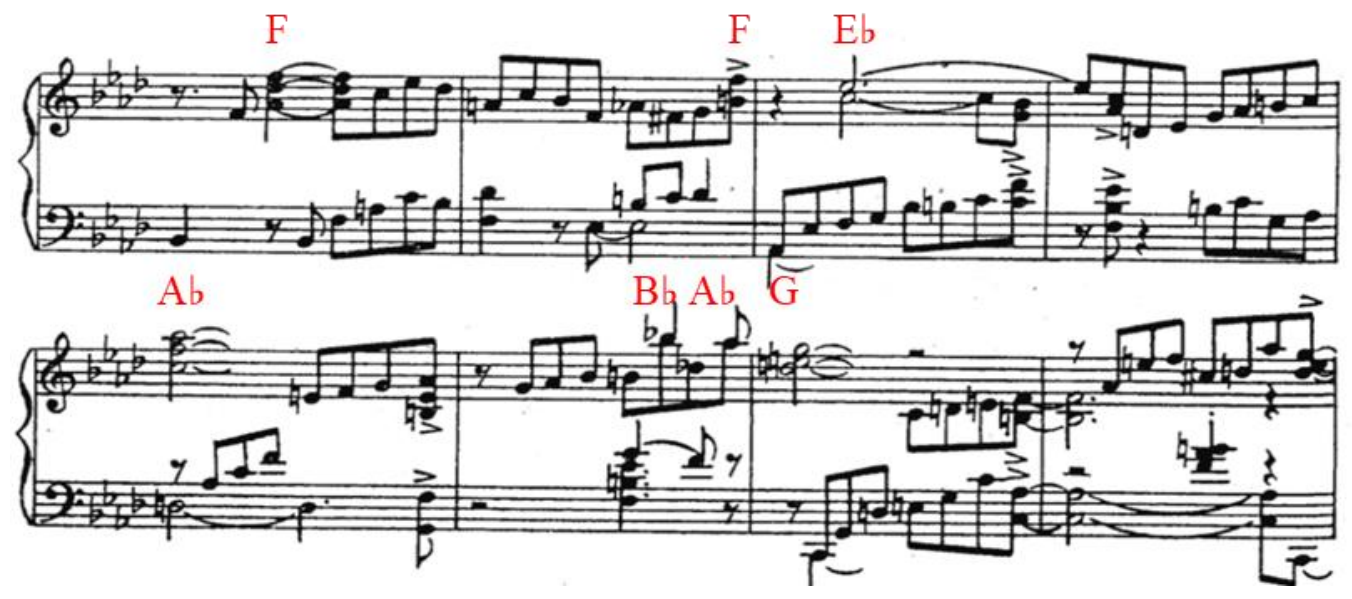

Example 36-b: Etude No. 8, mm. 13-20

The second A section (mm. 25-46) in Part I also consists of two phrases. The first phrase (mm. 25-32) resembles the first A section and is built on the same motive (C-D). The second phrase (mm. 33-46) contains the main melody (F-G-Ab-B) and is prolonged by melodic sequences, with the bass presenting a series of descending fifths (C\#-F\#-B-E-A) (Example 37).

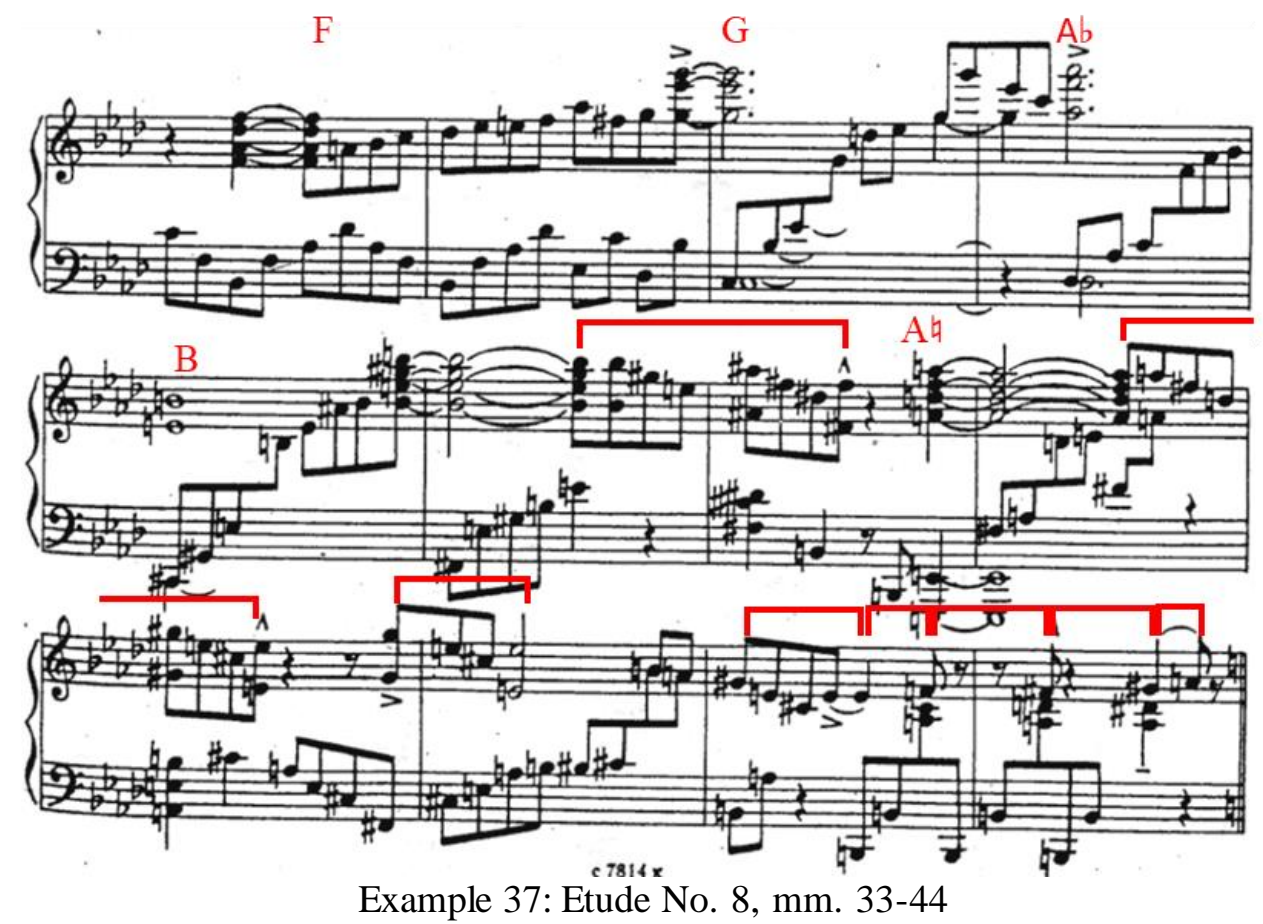


The B section (mm. 47-62) quotes melodic material from the second etude, which is mostly in stepwise motion (Example 38). The key signature in three flats is same as that of the second etude. To enhance the harmonic color, tritone substitution, a common jazz technique, is used in this section. In this procedure, one chord can be substituted for another whose root is a tritone away; for instance, in the key of $\mathrm{C}$ major, $\mathrm{G}_{7}$ is replaced by $\mathrm{Db}$ by sharing the pitches ( $\mathrm{F}$ and $\mathrm{Cb} / \mathrm{B}$. In this section we see two instances of tritone substitutions:122 In mm. 53, a substitution chord $\mathrm{D}_{7}$ is inserted to replace bVI of $\mathrm{c}$ minor, $\mathrm{Ab}$. And in $\mathrm{mm} .58, \mathrm{~A}_{7}$ is the tritone substitution for $\mathrm{Eb}$, bVI of g minor. Starting from the key of $\mathrm{Eb}$ major in $\mathrm{mm}$. 46, the key area shifts twice, to c minor and g minor.

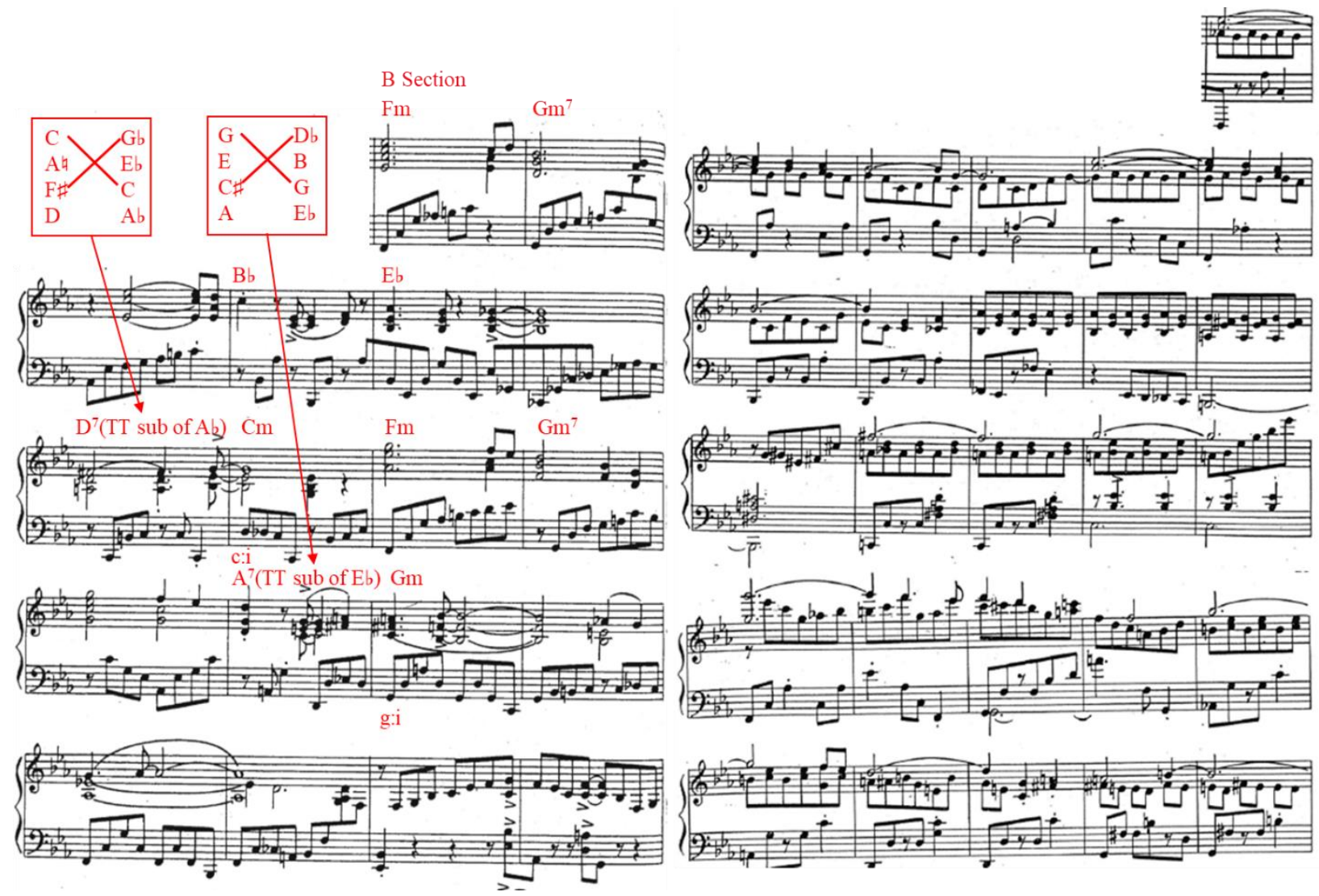

Example 38: Etude No. 8, B section, mm 47-62/Etude No. 2, mm. 27- 52

${ }^{122}$ Wang, "Fusion of Clas sical Virtuosity," 39. 
The $\mathrm{C}$ section (mm. 63-78) reveals $8+4$ phrases. It begins with an ascending major second and is based on the Eb-major pentatonic scale. The second phrase opens similarly, in the F-major pentatonic scale (Example 39).

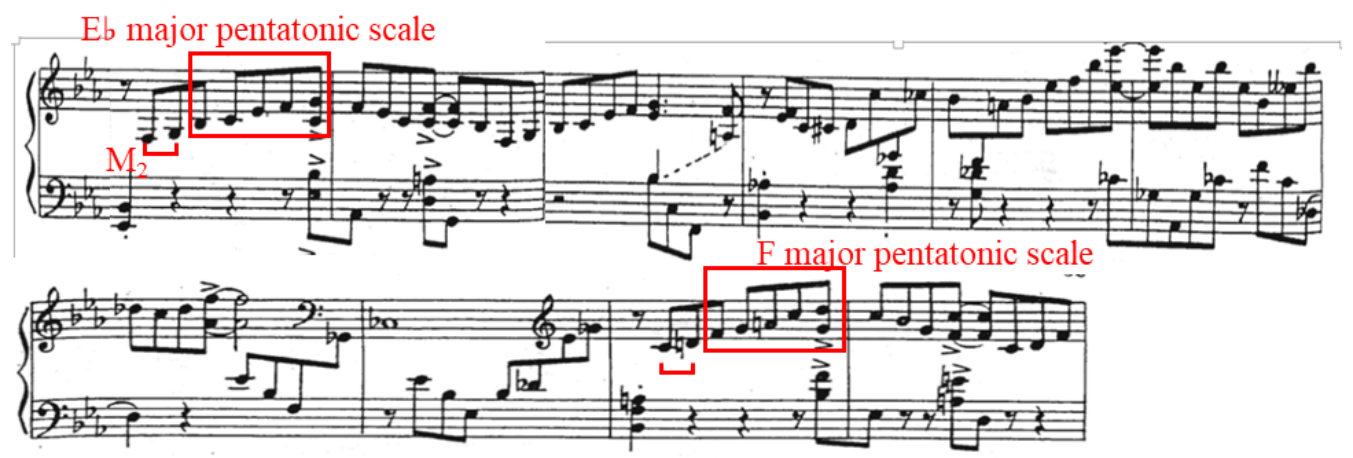

Example 39: Etude No. 8, part of C section, mm. 63-72

The transition (mm. 75-90) resembles a written-out improvisational passage, in which the left hand uses quartal harmonies and the right hand employs melodic sequences to create unexpected tension. The sustained $\mathrm{C}$ pedal point in the bass prepares the return to $\mathrm{f}$ minor (Example 40). 


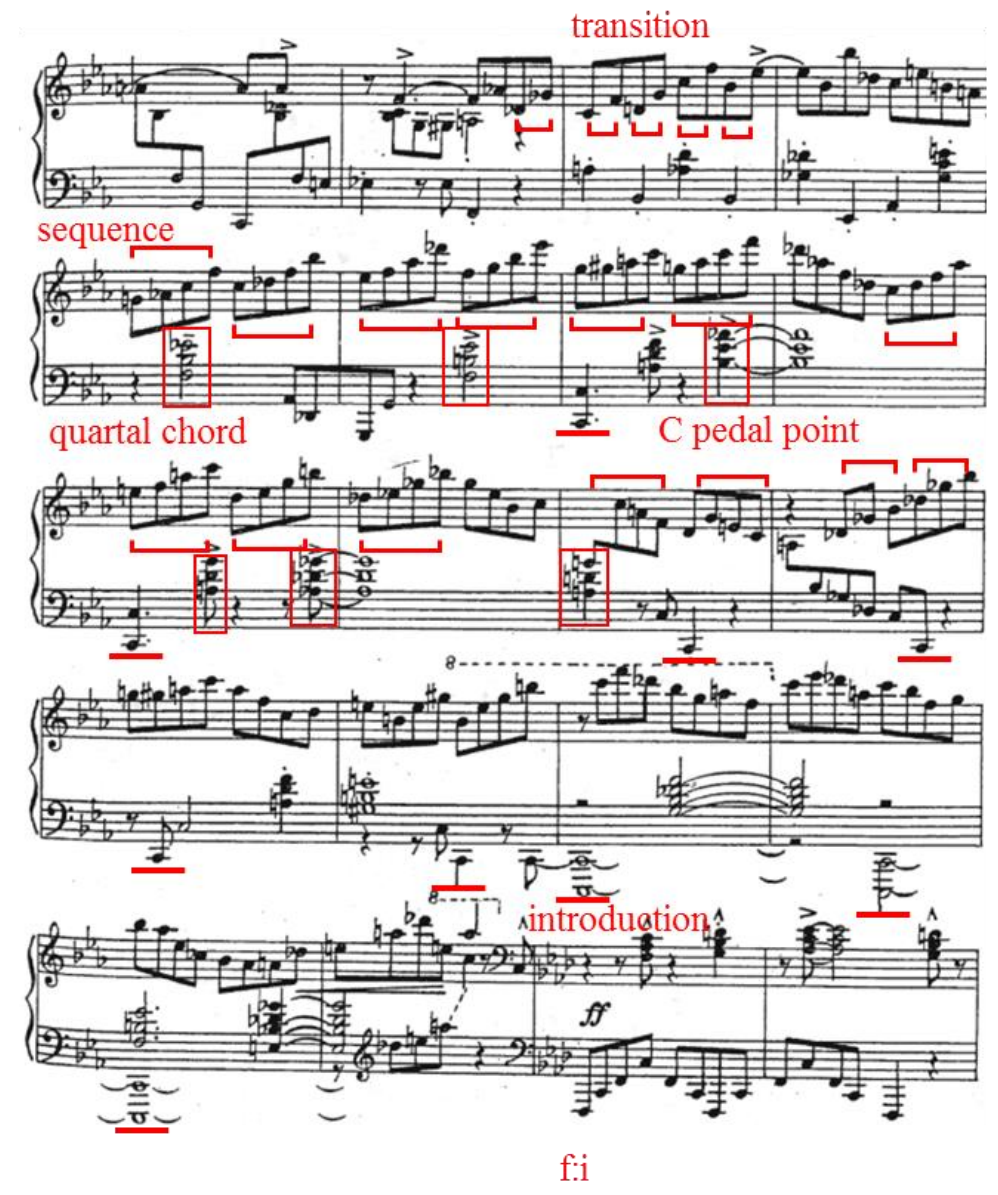

Example 40: Etude No. 8, transition, mm. 75-91

Kapustin again presents the material of the four-bar introduction. The A section in part II (mm. 95-132) returns to f minor, as in the first statement of this theme, but more elaborate in texture. The B section (mm. 133-148) is a varied version of the previous B section (mm. 47-62) material, but starting in $\mathrm{F}$ major instead of $\mathrm{Eb} . \mathrm{E}^{7}$ is the tritone substitution for $\mathrm{Bb}, \mathrm{bVI}$ of $\mathrm{d}$ minor in mm. 139 (Example 41). The key area shifts from $\mathrm{F}$ major to $\mathrm{d}$ minor, then to $\mathrm{g}$ minor. 


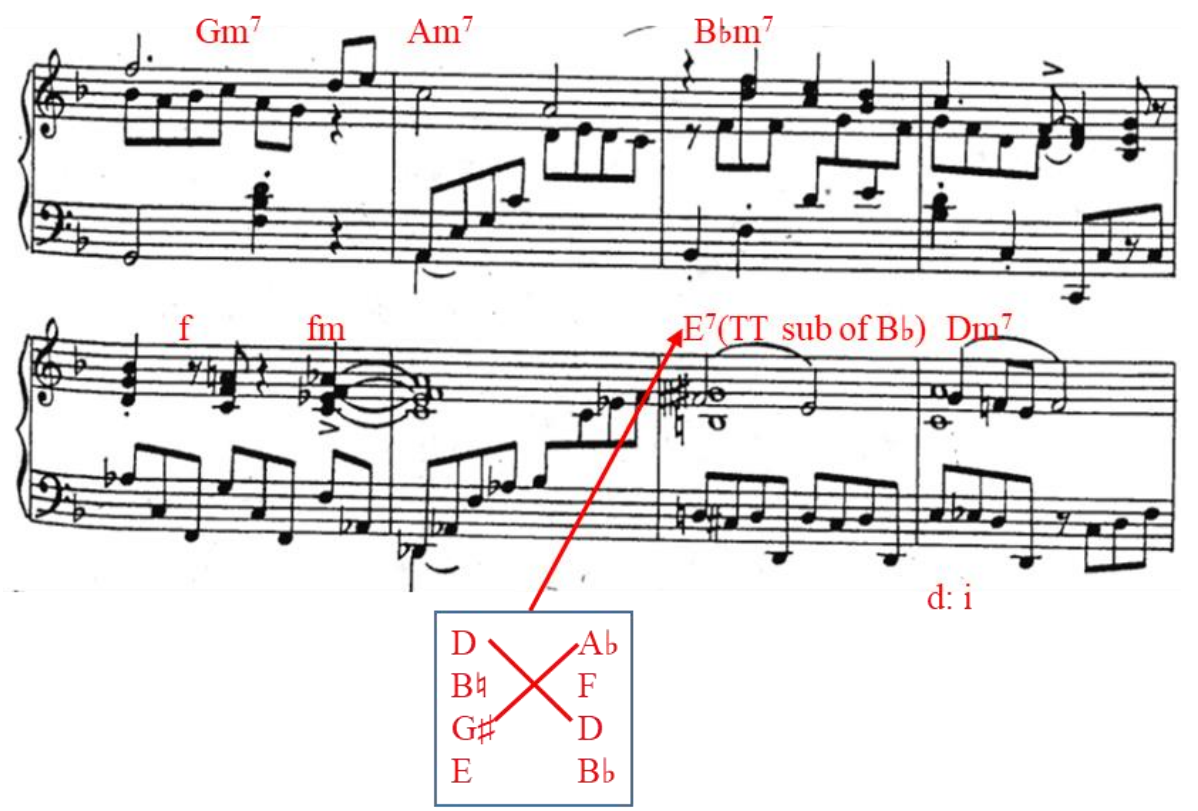

Example 41: Etude No. 8, mm. 137-140

The $\mathrm{C}$ section in Part II (149-168) begins with a pentatonic scale, as in the first presentation of this theme; but now we are in F major instead of $\mathrm{Eb}$ (Example 42). The second phrase (157168) opens in similar manner, with a C-major pentatonic scale.

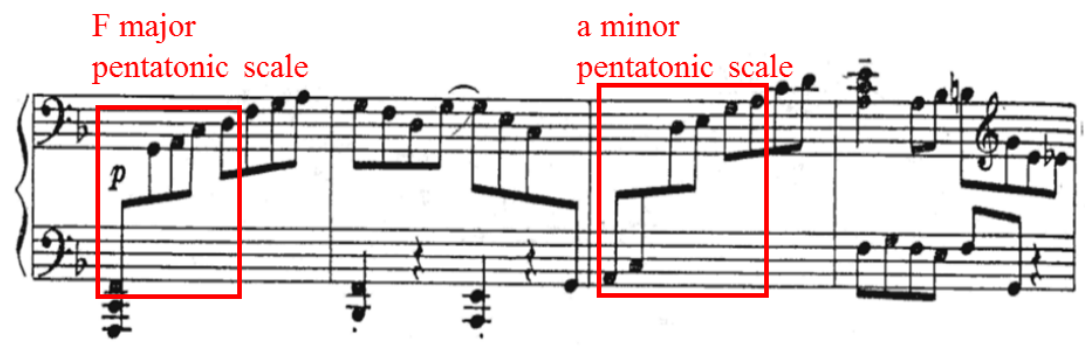

Example 42: Etude No. 8, mm. 149-152

The coda (mm. 169-192) returns to tonic, f minor; it is divided into two parts. The first part (mm. 169-180) uses material derived from the A section by moving the same chord an octave higher. The following passage resembles written-out improvisation in its use of melodic sequences to extend the tension. The ascending passage based on Ab-major pentatonic scales in parallel motion recalls a similar passage that appeared in Etude No. 1 (Prelude) (Example 43-a), 
where in parallel motion both hands play an ascending line based on fourths; then they quickly change to contrary motion, with the right hand featuring a pentatonic scale (Example 43-b). This motive is emphasized again in the final chords by descending in minor seconds $(\mathrm{Cb}-\mathrm{B} b-\mathrm{A}-\mathrm{Ab})$.

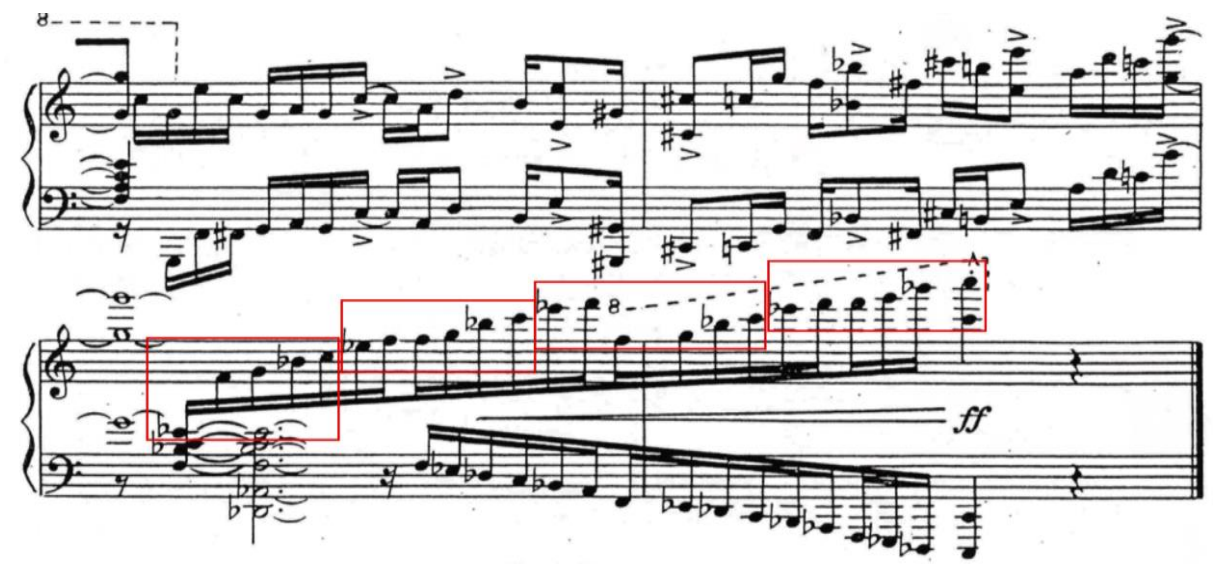

Example 43-a: Etude No. 1, mm. 67-70 


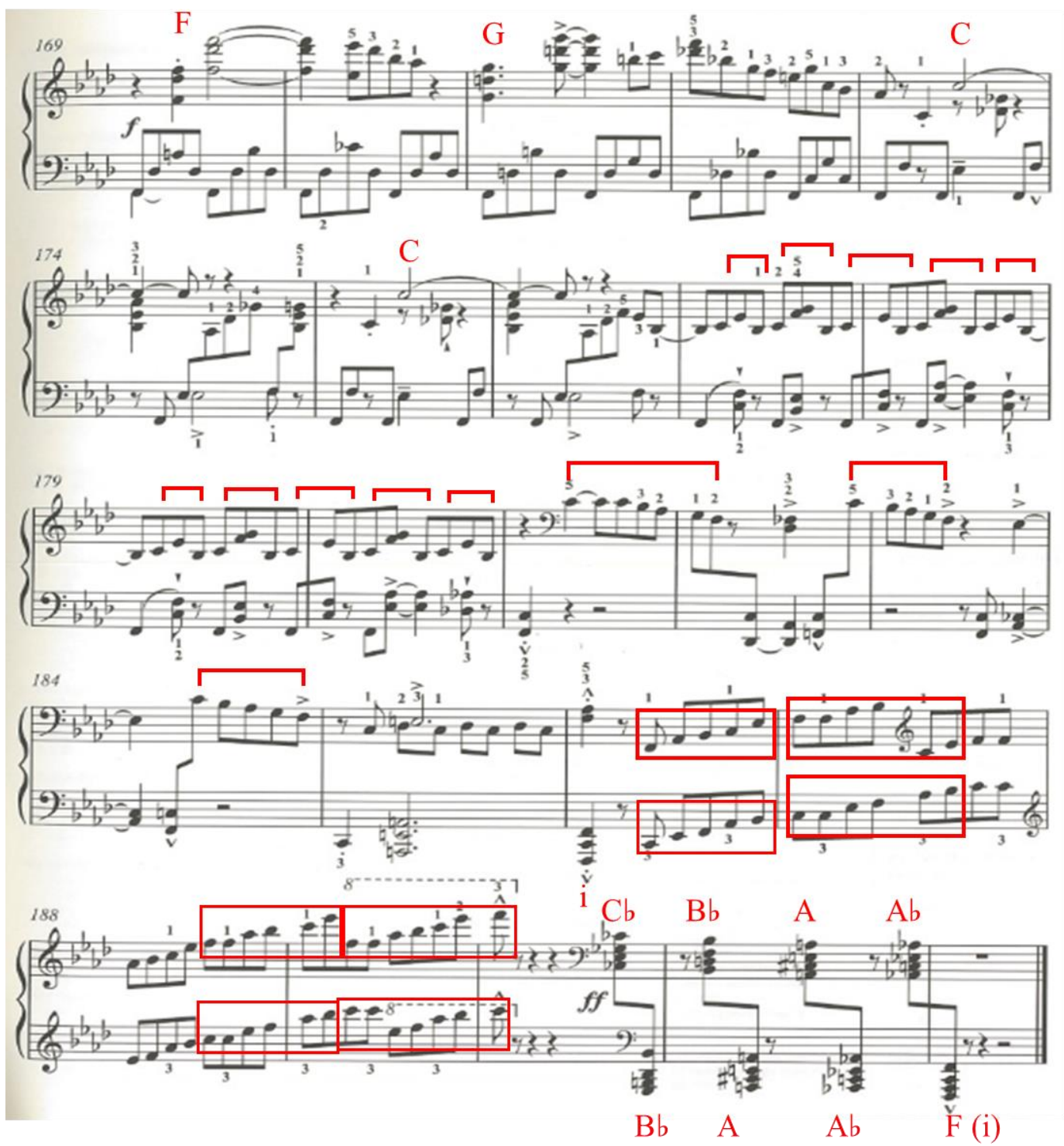

Example 43-b: Etude No. 8, mm. 169-192

\subsection{Performance Considerations}

From the performance-practice point of view, it is a totally different experience for classically trained students to start learning these jazz-style etudes, because jazz and classical music have very different traditions and focal points. First of all, not all the passages are performed exactly as written due to the typical characteristics of jazz music, which might be a bit confusing for classically trained piano students, but are explicitly understood by jazz players. For 
example, when performing a swing piece or passage, a pair of eighth notes should be read as "long-short triplet rhythm." For instance, Etude No. 5 (Raillery) contains a "swing" section beginning in $\mathrm{m} .61$. According to the swing character and the interpretation confirmed by recordings of Kapustin's own performance, mm. 69-72, written in even eighth notes, should be played in a long-short triplet $\left(\overrightarrow{\left.\bullet \cdot \bullet^{3} \widehat{\odot}\right)}\right.$ ) rhythm (Example 44). The same issue also occurs in other Kapustin works; for instance, mm. 39-40 from No. 23 in F major of 24 Preludes, Op. 53 (Example 45), notated as even eighth notes, should be played in a long-short triplet rhythm.

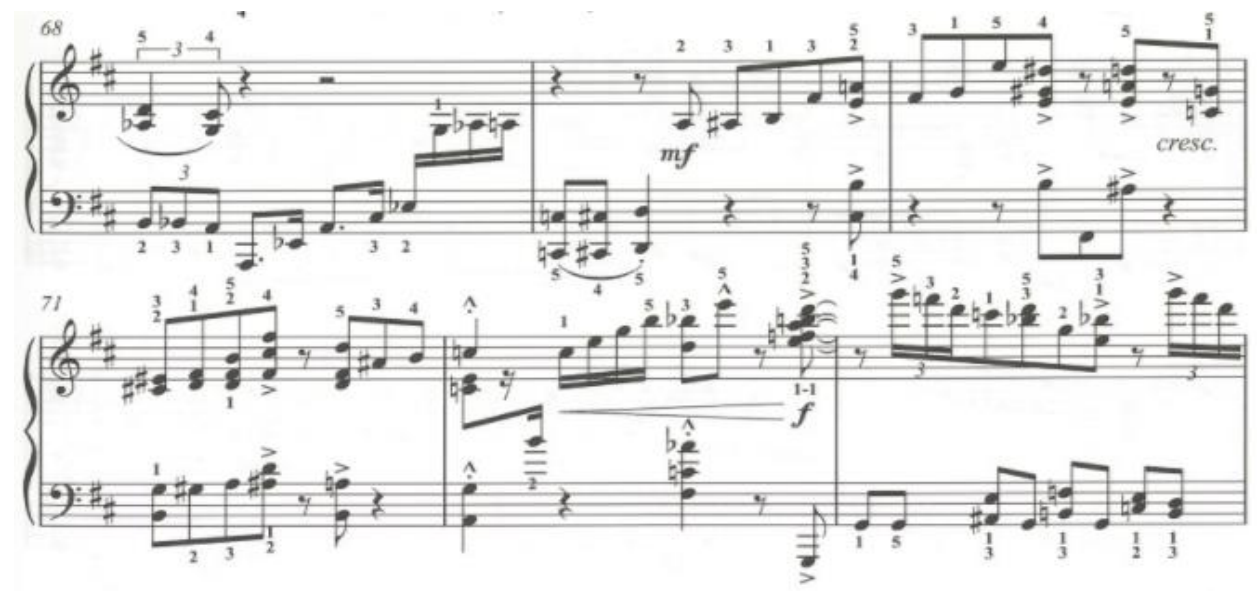

Example 44: Etude No. 5, mm. 68- 73

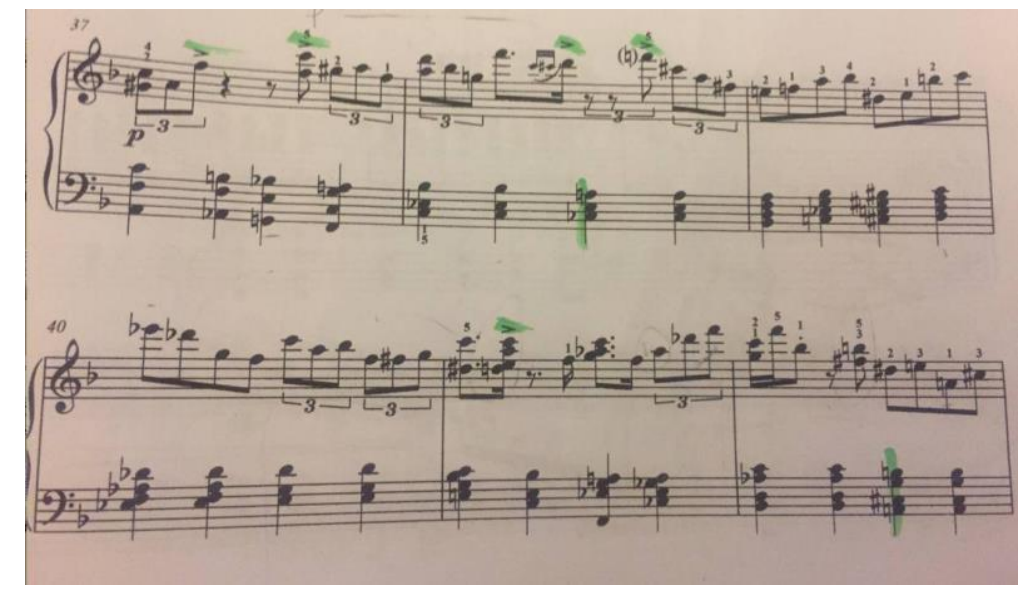

Example 45: No. 23 in F major of 24 Preludes, Op. 53, mm. 37-42 
Secondly, making efforts to become comfortable with jazz rhythms would be helpful for learning and practicing these pieces. Compared to classical music, where the first and third beats are emphasized in a stable pulse and timing, jazz frequently emphasizes the off-beat or weak beat, which gives an unstable and changeable feeling. It would be also helpful to listen to recordings of these pieces or related jazz performances, such as instrumental or vocal jazz, to become familiar with the overall feeling and to understand the jazz character better.

Thirdly, more flexible or free-flowing timing is consistent with the jazz characteristics in these etudes. Compared to the expectation in much classical music for "perfect" or straight timing, together with the metronome, jazz works in the opposite way by being "around the beat," that is, ahead of or behind it. For instance, in the Etude No. 7 (Intermezzo), the expression mark "liberamente" (A-RAM edition) is placed after the tempo marking, meaning that the performer should play freely and never mechanically with regard to tempo and rhythm.

Other concerns about practicing these pieces include careful music score reading, since Kapustin consistently handles the same source of material in different ways and repetitions are rarely the same. When choosing fingerings, students should experiment to find the best choices during the learning process, even if fingering is provided in the score, since what is suggested by the editor may not be optimum for everyone. In that regard, the Schott edition includes fingering, while the A-RAM edition does not.

As highly artistic character pieces, Eight Concert Etudes, Op. 40, cover a wide range of musical styles and require mastering a variety of virtuosic techniques, making them more suitable for advanced or college-level students. 


\section{Chapter VI: Conclusion}

Piano etudes play an important role in learning for students on every level. For beginners or intermediate-level students, it is helpful for them to practice etudes to develop their piano skills. For college or advanced-level students who have good musical background, etudes still offer tremendous benefits for consolidating and strengthening their piano skills as well as expanding their repertoires. Thousands of etudes have been written throughout musical history, providing an ample supply of material for students to choose.

In this research project, Chapter IV surveys the history of piano etudes from their first appearance to the $20^{\text {th }}$ century. That chapter lists a large number of etudes, providing a resource for teachers to explore if they wish to expand their students' repertoire options for developing technical skills and musical sensitivity, as well as exploring the musical styles of different periods. This chapter might also serve as a starting-off place for someone else to launch a bigger study.

As a $20^{\text {th }}$-century composer well-known for the fusion of classical traditions and jazz style, Kapustin is not the first composer to adopt jazz elements into classical music. Many other composers preceded him in making significant efforts in this regard. For instance, the influence of jazz on Debussy appears in Golliwog's Cake Walk, the sixth piece from Children's Corner (1906-1908). Aaron Copland (1900-1990) wrote a set of short blues, Four Piano Blues (19261948), which exhibit a more direct jazz influence. Furthermore, Kapustin is not the first composer to blend jazz style into the etude genre. For example, Erwin Schulhoff (1894-1942) composed Five Etudes de Jazz for piano (1910-1920). 
As summarized in Chapter III, understanding Kapustin's biography and seeing an overview of his piano works reveals that, compared to other composers who wrote music with jazz elements in a limited number of their compositions, Kapustin has been immersed in jazz throughout his music career and his compositions spring from very deep jazz roots. He also was a virtuoso classical concert pianist and he consistently employs classical forms in his compositions.

There are reasons to debate whether Kapustin's music is classical or jazz. Chapter V investigates structural, technical and stylistic aspects of his Eight Concert Etudes, Op. 40, from both classical and jazz perspectives. In each etude, Kapustin makes significant technical demands by blending traditional piano techniques (passages of rapid scales or arpeggios, double notes, octaves, repeated notes, large skips, etc.) with jazz chords and harmonies, jazz rhythms (syncopation, swing, etc.), jazz scales (blues, bebop, pentatonic, etc.) and jazz improvisation.

It is clear that jazz and traditional techniques are tightly combined in these etudes and that each etude addresses more than one technical problem. The formal structures exhibited in these etudes are varied, but mostly show classical forms, such as ternary constructions. By contrast, Etudes 3 and 6 reveal jazz song forms.

Kapustin uses classical compositional techniques while blending the harmonic and rhythmic elements of modern jazz throughout his etudes. For instance, he uses thematic transformation within the swing style of Etude No. 7 (Intermezzo) and employs the smallest unit of an idea in improvisatory ways in No. 8 (Finale).

Thus we see that, as embodied in his etudes, classical and jazz influences are intertwined with each other and it is difficult to determine which is more important than the other. Kapustin himself reflected on this issue in an early interview: 
The interesting thing for me was always this fusion between classical and jazz, classical forms and a jazzy idiom.... For me the clas sical part is more important. The jazz style is there to give color. ${ }^{123}$

In summary, this research project provides a brief overview and pedagogical exploration of Kapustin's Eight Concert Etudes, Op. 40, adding to other authors' studies of etudes composed in the $20^{\text {th }}$ century and expanding the investigation of the fusion between classical and jazz styles. This project also expresses sincere admiration for Kapustin's compositional brilliance, with the hope both to encourage other writers to conduct further studies in this area and also to invite more classical pianists to explore playing new repertoire in a wide range of styles, including jazz.

${ }^{123}$ Harriet Smith. Bridging the Divide: An Interview with Kapustin. International Piano Quarterly. 2000; 4(13): 5455. 


\section{Bibliography}

De'Ath, Leslie. 'Nikolai Kapustin-A Performer's Perspective." MusicWeb International (June 2002), http://www.musicweb-international.com/classRev/2002/Jun02/Kapustin.htm (accessed June 20, 2014)

“Oxford Music Online.” Accessed Nov. 20, 2018. http:/www.oxfordmusiconline.com/.

Grigor'yeva, Alla Vladimirovna. "Kapustin, Nikolay Girshevich.” The New Grove Dictionary of Music and Musicians, 2001.

"Nikolai Kapustin." Accessed Nov. 10, 2018. http//www.nikolai-kapustin.info/.

"MusicWeb International: Classical Music Reviews \& Resources." Accessed Nov. 10, 2018. http://musicweb-international.com/.

Schuller, Gunther, and Thomas H. Greenland. "Third stream."

https//doi.org/10.1093/gmo/9781561592630.article.A2252527 (accessed March 01, 2019).

Tyulkova, Yana. "Classical and Jazz Influences in the Music of Nikolai Kapustin: Piano Sonata No. 3, Op. 55.” DMA diss., West Virginia University, 2015.

Mann, Jonathan Edward. "Red, White, and Blue Notes: The Symbiotic Music of Nikolai Kapustin.” PhD diss., University of Cincinnati, 2007.

Abramova, Tatiana. "The Synthesis of Jazz and Classical Styles in Three Piano Works of Nikolai Kapustin.” DMA diss., Temple University, 2014. ProQuest Dissertations Publishing.

Wang, Ruby. "Fusion of Classical Virtuosity and Jazz Techniques in the Etudes of Nikolai Kapustin: 'Eight Concert Etudes,' Op. 40, and 'Five Etudes in Different Intervals,' Op. 68." DMA diss., University of South Carolina, 2014.

Okamoto, Akane. "Nicholai Kapustin's Eight Concert Etudes, Op. 40: Reflections on Analysis, Practice, and Performance." PhD diss., University of Toronto, 2013.

Becker, Alan. "Guide to Records-Kapustin: 24 Preludes in Jazz Style." American Record Guide 74, no. 1 (2011).

Anderson, Martin. "Nikolai Kapustin, Russian Composer of Classical Jazz." Fanfare, Sept/Oct. 2000.

Smith, Harriet. "Bridging the Divide: An Interview with Kapustin." International Piano Quarterly 4, no. 13 (2000). 
Roberts, Jonathan. "Classical Jazz: The Life and Musical Innovations of Nikolai Kapustin." DMA diss., University of Alabama, 2013.

Steele, Susannah. 'Nikolai Kapustin's 'Ten Bagatelles,' Op. 59.” DMA diss., the University of North Carolina at Greensboro, 2013.

Peters, Mark. “A Study of Nikolai Kapustin's Sonata No. 12, Op. 102: A Contemporary Jazz Sonata in Two Movements.” DMA diss., West Virginia University, 2017.

Kelly, Ryan T. “The Big Band and the Piano: Nikolai Kapustin's Variations Op. 41.” DMA diss., Manhattan School of Music, 2016.

Kapustin, Nikolai. “Twenty-Four Preludes, Op. 53.” Moscow: A-RAM, 2004.

Creighton, Randall J. "A Man of Two Worlds: Classical and Jazz Influences in Nikolai Kapustin's Twenty-Four Preludes, Op. 53.” DMA diss., The University of Arizona, 2009.

Seong, Sekyeong. "Bagatelles No. 6 and No. 8, Op. 59 by Nikolai Kapustin: Background, Analysis, and Performance Guideline." DMA diss., The Ohio State University, 2015.

Ye, Qingqing. 'Nikolai Kapustin's Solo Piano Works 2007-2013: A Recording and Performance Guide.” DMA diss., Arizona State University, 2018.

Ganz, Peter Felix. "The Development of the Etude for Pianoforte." PhD diss., Northwestern University, 1960.

"Merriam-Webster Dictionary." accessed Apr. 06, 2019. https://www.merriamwebster.com/dictionary/study\#etymology/.

Apel, Will. Harvard Dictionary of Music. Cambridge, Mass.: Harvard University Press, 1955.

Burkholder, J. Peter, Donald Jay Grout, and Claude V. Palisca. A History of Western Music, $7^{\text {th }}$ edition. New York: W.W. Norton, 2005.

Au, Angelina Ngan-chu. "The Piano Etude in the Nineteenth Century: From the Acquisition of Facility to Demonstration of Virtuosity.” DMA diss., University of Cincinnati, 1999.

Gordon, Stewart. A History of Keyboard Literature. New York: Schirmer, 1996.

Cho, Sun-Im. "Johann Nepomuk Hummel's Piano Etudes, Op. 125: A Pedagogical Analysis." DMA diss., The City University of New York, 2012.

“IMSLP Petrucci Music Library.” Accessed Apr. 05, 2019. https://imslp.org/wiki/Main_Page/.

"Works of Virgil Thomson." Accessed Apr. 05, 2019. http:/works.virgilthomson.org/.

Rae, Caroline. "The Piano Music of Maurice Ohana." Revista Música 6, no. 1-2 (1995). 
"George Perle." Accessed Apr. 05, 2019. https://georgeperle.net/catalog/solo-and-chambermusic/.

"Noël Lee." Accessed Apr. 05, 2019. http://www.noel-lee.com/english/compositions.htm/.

"Etydit-Etudes by Einojuhani Rautavaara." Accessed Apr. 05, 2019.

https://core.musicfinland.fi/works/etydit-etudes-d98feb32-75e5-4630-be63-927903c4283c/.

“Composer John Corigliano.” Accessed Apr. 05, 2019.

http://www.johncorigliano.com/index.php? $\mathrm{p}=$ item $2 \&$ item $=61 /$.

Yeh, I-Chen. "The Piano Etudes of David Rakowski." DMA diss., Bowling Green State University, 2010.

Kim, Soo Kyung. "A Study of Unsuk Chin's Piano Etudes." DMA diss., the University of Georgia, 2012.

Mathews, Aaron Balthazar. "H. Leslie Adams' Twenty-Six Etudes for Solo Piano: A Performance and Stylistic Analysis." DMA diss., University of South Carolina, 2015.

Kang, Eun Young. "Late Twentieth-Century Piano Concert Etudes: A Style Study.” DMA diss., University of Cincinnati, 2010.

Levine, Mark. The Jazz Theory Book. Petaluma, CA: Sher Music Co., 1995.

Choi, Jiwon. "An Eclectic Combination of Classical and Jazz Idioms: Nikolai Kapustin's Piano Works." PhD diss., University of Kansas, 2015.

Erickson, Robert. Sound Structure in Music. Los Angeles, CA: University of California Press, Ltd., 1975.

Rushton, Julian. "Ninth chord." Grove Music Online, Jan. 20, 2001. Accessed Apr. 06, 2019. http://www.oxfordmusiconline.com/grovemusic/view/10.1093/gmo/9781561592630.001.0001/o mo-9781561592630-e-0000019979. 